UNIVERSIDADE DE SÃO PAULO

FACULDADE DE FILOSOFIA, LETRAS E CIÊNCIAS HUMANAS

DEPARTAMENTO DE GEOGRAFIA

PROGRAMA DE PÓS-GRADUAÇÃO EM GEOGRAFIA FÍSICA

\title{
GEOGRAFIA E EDUCAÇÃO INFANTIL: \\ OS CROQUIS DE LOCALIZAÇÃO - UM ESTUDO DE CASO
}

Maria Luiza Sardinha de Nóbrega

Tese apresentada ao Programa de Pós-Graduação em Geografia Física, do Departamento de Geografia, da Faculdade de Filosofia, Letras e Ciências Humanas da Universidade de São Paulo, para obtenção do título de Doutor em Geografia.

Orientador: Prof. Dra . Maria Elena Ramos Simielli

São Paulo 
Aos queridos João Batista e João Victor, pelo companheirismo, compreensão e paciência. 


\section{AGRADECIMENTOS}

À Profa Dra $^{\mathrm{a}}$ Maria Elena, pela orientação serena e firme, baseada no princípio da liberdade e da solidariedade a quem devo a oportunidade de construir este caminho.

Ao mais que amigo Paulo Eduardo, pelo acompanhamento, leitura crítica e disposição em acolher minhas dificuldades, revelando-se, afinal, um Mestre.

À Professora Cleide Terzi, que mostrou a direção.

À minha pequena família, marido e filho, que se organizaram em função das necessidades de realização das muitas tarefas que este trabalho acabou impondo a nós todos.

À amiga Líria, cuja presença solidária permitiu que eu finalizasse este estudo.

À Denise Ferreira, do Departamento de Educação Infantil da Secretaria Municipal de Educação da Prefeitura de Diadema, uma companheira educadora que conhece ampla e profundamente o sentido e os compromissos da Educação e da Escola Públicas.

À Equipe da Escola Serraria, na pessoa da Professora Sandra, que passo a considerar, a partir desta trajetória, uma grande educadora brasileira. Lúcida, comprometida, formada para atuar a partir dos princípios didáticos e pedagógicos em condições de assegurar acesso e permanência na escola às crianças sob sua responsabilidade.

À Equipe do Núcleo Educacional Brincar e Aprender, na pessoa da Professora Miriam, que faz educação de qualidade social, contando apenas com o esforço de sua comunidade escolar e de sua competência para educar, sem, entretanto, abrir mão do rigor na observação dos princípios educativos. 


\section{RESUMO}

Este trabalho trata das questões relativas ao ensino na Educação Infantil através da investigação das contribuições que os croquis de localização oferecem ao processo formativo das crianças pequenas. Busca nas teorias sócio-históricas os fundamentos para compreender a importância da mediação no aprendizado das crianças, defendendo que os croquis são importantes instrumentos no processo ensino-aprendizagem. Recorre à Geografia para compreender os conceitos essenciais, lugar e paisagem, representações e linguagem gráfica, discutindo a espacialização das crianças como processo que exige sistematização e planejamento. O Estudo identifica nas práticas pedagógicas a possibilidade de garantir os fundamentos para uma formação que aprimore as práticas socioespaciais na perspectiva de construção e fortalecimento da cidadania ativa. A Educação Infantil é compreendida na dimensão do direito, assegurado a toda criança. A ação educativa capaz de tratar das questões relativas ao Conhecimento de Mundo que se deve assegurar às crianças deve estar fundamentada na Ciência, no conhecimento filosófico, na Arte e na Ética.

Palavra-chave: Geografia; Educação Infantil; croquis geográficos; práticas socioespaciais; cidadania. 


\begin{abstract}
This work deals with questions related to the infant education teaching through the investigation of the contributions that the sketches of the localization offer to the formative process of small children. It searches on social historic theories the basis to understand the importance of the mediation on children's apprenticeship, defending that sketches are important tools on the teachingapprenticeship process. It recurs to the geography to comprehend the essential concepts, place and landscape, representations and graphic language, discussing the spaciousness of the children as a process that demands systematization and planning. The Study identifies in the pedagogic practices the possibility to guarantee the principles for a formation that improves the social-spatial practices on the perspective of the construction and enforcement of the active citizenship. The infant education is understood on the dimension of the law, assured to all children. The educative action able to treat these matters related to the world knowledge that must be assured to children, it must be based upon science, on philosophic knowledge, on art and ethic.
\end{abstract}

Key-words: geography; infant education teaching; geographic sketches; socialspatial practices; citizenship. 
CAPITULO I - POLÍTICAS EDUCACIONAIS E REFORMAS DO ENSINO NO BRASIL $(1990$ - 2000)

A construção da Educação Básica no Brasil: incluindo a Educação Infantil.

Uma Educação que se construiu a partir de cima ......................................23

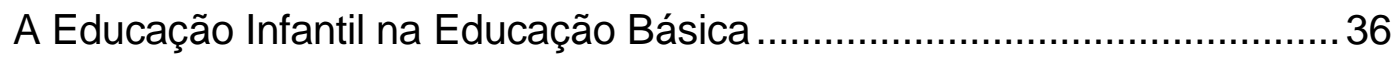

O Referencial Curricular Nacional para a Educação Infantil ........................ 38

A importância do educar-cuidar em Educação Infantil .............................. 42

CAPÍTULO II - NATUREZA E SOCIEDADE ............................................... 45

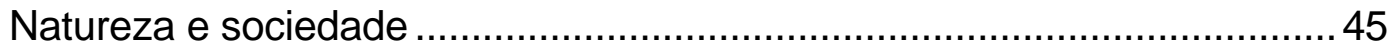

O Conhecimento Geográfico em busca de espaço, na Instituição

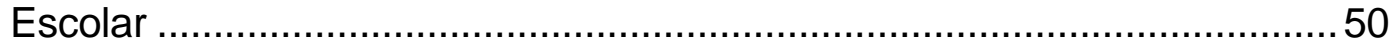

A Geografia Escolar nas Séries Iniciais - uma reflexão............................... 52

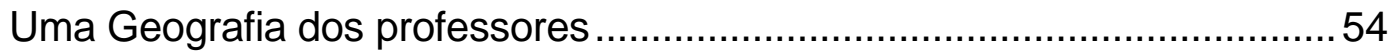

Representações Gráficas e Croquis: Uma aproximação com o eixo Conhecimento de Mundo - Natureza e Sociedade na Educação Infantil.....

O Referencial Curricular Nacional para a Educação Infantil Volume III

A organização do Volume III do RCNEI - Conhecimento de mundo

Critérios para a escolha de conteúdos na Educação Infantil: uma discussão do interesse da Geografia? ...................................69 69

Organizando "os blocos de conteúdos": arranjos possíveis ............. 73

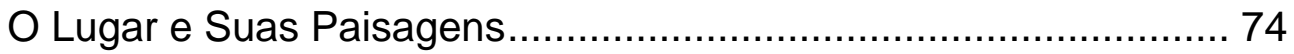


CAPÍTULO III - A TEORIA SÓCIO-HISTÓRICA: CONTRIBUIÇÕES DE

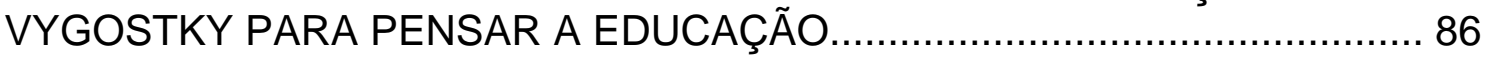

A aprendizagem e o desenvolvimento da criança, na Educação Infantil .... 86

Elementos da teoria sócio-histórica

A Mediação como pressuposto essencial do desenvolvimento infantil - A ação educativa em foco

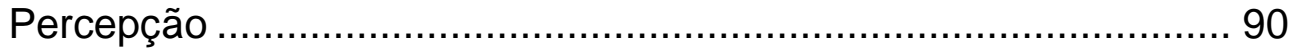

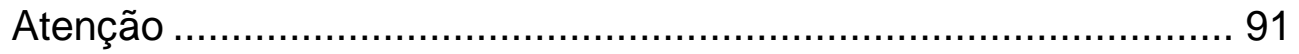

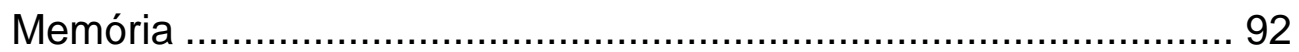

Os Processos de Internalização ..................................................... 94

A relevância dos processos de interação entre o aprendizado e o

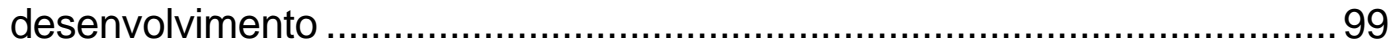

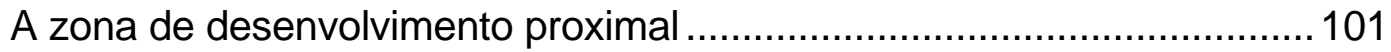

Impactos das teorias sócio-históricas no ensino …………………...........106

CAPÍTULO IV - CROQUIS DE LOCALIZAÇÃO E EDUCAÇÃO INFANTIL: O ESTUDO DE CASO

A interpretação dos croquis de localização: uma possibilidade didática?

Definindo os croquis de localização.

O estudo de caso como base para indagações acerca da interpretação que as crianças fazem dos croquis de localização

A Educação Infantil no município de Diadema - o contexto de realização do estudo de caso 126

Local e procedimentos do estudo......

A construção da atividade envolvida no estudo de campo

A etapa de pré-teste na construção da atividade 137

A organização da atividade e sua finalidade 140

Desenvolvimento da atividade

Apresentação e análise das situações de interpretação do croqui de localização.....

Atividade A 145

Atividade B 166 


\section{INTRODUÇÃO}

A finalidade deste estudo é propor a reflexão sobre as contribuições da Geografia para o ensino na Educação Infantil, considerando os eixos temáticos como possibilidade de organização curricular para esse nível de ensino, a partir do uso de croquis de localização.

A proposta inicial era trabalhar com essa questão a partir das séries iniciais. Ao investigar o contexto educacional, reorganizado a partir da Lei de Diretrizes e Bases promulgada em 1996, conclui que havia possibilidade de se pensar a questão do ensino numa perspectiva que articula os níveis iniciais da Educação Básica.

Tomando a formação do professor de séries iniciais e Educação Infantil que ocorre na mesma licenciatura e a partir do mesmo projeto pedagógico, conclui que há espaço para a pesquisa que adote essa perspectiva como hipótese de superação de alguns problemas fundamentais na escolarização das crianças.

A primeira questão é relativa a antecipação da escolarização das séries iniciais para a Educação Infantil. Há grande preocupação no campo educacional em superar certo modelo pedagógico que vai adaptando os procedimentos didáticos daquela etapa neste nível inicial da Educação Básica.

A segunda questão diz respeito a dificuldade do professor em atuar no sentido de decidir sobre o que é relevante ensinar. Assim decidi tomar a Geografia como campo de interesse e investigar em que medida os saberes desse campo podem compor os arranjos curriculares da Educação Básica. E o fiz detendo minha atenção no nível inicial: a Educação Infantil.

Nos cursos superiores de Pedagogia somente a partir das novas diretrizes de formação foram introduzidas as metodologias para o ensino das áreas do conhecimento, de acordo com os PCN (Parâmetros Curriculares Nacionais). Esse futuro professor das séries iniciais e da educação infantil enfrenta 
problemas cruciais em sua formação para realizar o trabalho didático que lhe compete: a partir dos saberes dos diversos campos do conhecimento realizar a transposição didática do campo acadêmico para o escolar. E fazê-lo através de seqüências didáticas adequadas as necessidades formativas das crianças.

Escolhi trabalhar com a Geografia por ser este um campo científico relevante para a formação das crianças, capaz de oferecer subsídios para a reflexão acerca da dimensão didática e pedagógica e da gestão. É crescente a necessidade de se ampliar a compreensão do papel do ambiente, dos espaços vividos pela criança, as relações socioespaciais que aí ocorrem como uma dimensão da formação para a cidadania.

Instigada pela leitura de Yves Lacoste, geógrafo e historiador francês, passei a me dedicar ao estudo das questões envolvendo a espacialidade na formação de jovens e crianças e de professores, em função de minha atividade profissional, já que sou professora de séries inicias e do nível Superior, em Licenciaturas.

Interessada em compreender tal questão, decidi me desafiar a elaborar um problema crucial das séries iniciais: o ensino de Geografia e seus procedimentos didáticos, pensados a partir de uma situação mediada em que representações gráficas fossem os instrumentos e os conteúdos da atividade e em que os alunos protagonistas solucionassem a situação problema apresentada. A idéia inicial era trabalhar com croquis de empreendimentos imobiliários em situações que envolvessem os conteúdos formais e as características do entorno da escola. Um conjunto de fatores remeteria tal decisão inicial a outro campo.

Observo, em minha trajetória profissional, que educadores, jovens e crianças apropriam-se muito pouco dos espaços da escola, do lugar de vivências (o bairro, a vila, a comunidade) e suas características relevantes. A própria escola enfrenta dificuldades para localizar-se em determinada condição socioespacial. Isto acarreta problemas não só no âmbito do ensino como também na esfera da gestão pedagógica, na medida em que a dificuldade em realizar 
diagnósticos da situação da escola na dimensão das práticas sociais, das relações ali estabelecidas entre as pessoas, o meio ambiente e sócio econômico compromete o processo decisório em torno do projeto pedagógico.

Uma questão relevante para a prática educativa, no âmbito da gestão escolar, é a possibilidade de a escola compreender o lugar em que atua. Lugar aqui compreendido a partir de referência conceitual, que apresento no próximo capítulo.

A prática pedagógica significativa, hoje transformada em discurso salvacionista das situações que envolvem o processo ensino-aprendizagem, só pode construir-se a partir da possibilidade da escola, enquanto instituição educativa, identificar, construir e democratizar os saberes e conhecimentos que a tornam significativa. Isto inclui a possibilidade de lidar com os conhecimentos geográficos.

As comunidades escolares constituem espacialidades diferenciais ${ }^{1}$ que estão presentes nas localidades. Assim o conhecimento geográfico torna-se essencial para a condução dos processos educativos seja no âmbito da organização curricular, seja no âmbito da gestão. Interessei-me por pensar nestes termos a partir das reflexões suscitadas pela leitura de Lacoste.

Uma ilustração do que significa a espacialidade diferencial, pode ser tomada de um fato que acaba de ocorrer quando finalizo este trabalho. Na capital de São Paulo, uma cratera se abre sob o bairro de Pinheiros, junto a futura estação de metrô, como conseqüência do que parece ser uma imperícia nos modos de manejo de implosões/explosões destinadas a abertura dos túneis. Há sete vítimas.

1 Espacialidade diferencial: conceito proposto por Lacoste, a partir de Reynaud (1974), mas de forma diferente, "feita de uma multiplicidade de representações espaciais, de dimensões muito diversas, que correspondem a toda uma série de práticas e idéias, mais ou menos dissociadas, incluindo representações do espaço relativas a diferentes deslocamentos, diferentes redes que constituem conjuntos espaciais não coincidentes" (LACOSTE, 2006: 49-50). 


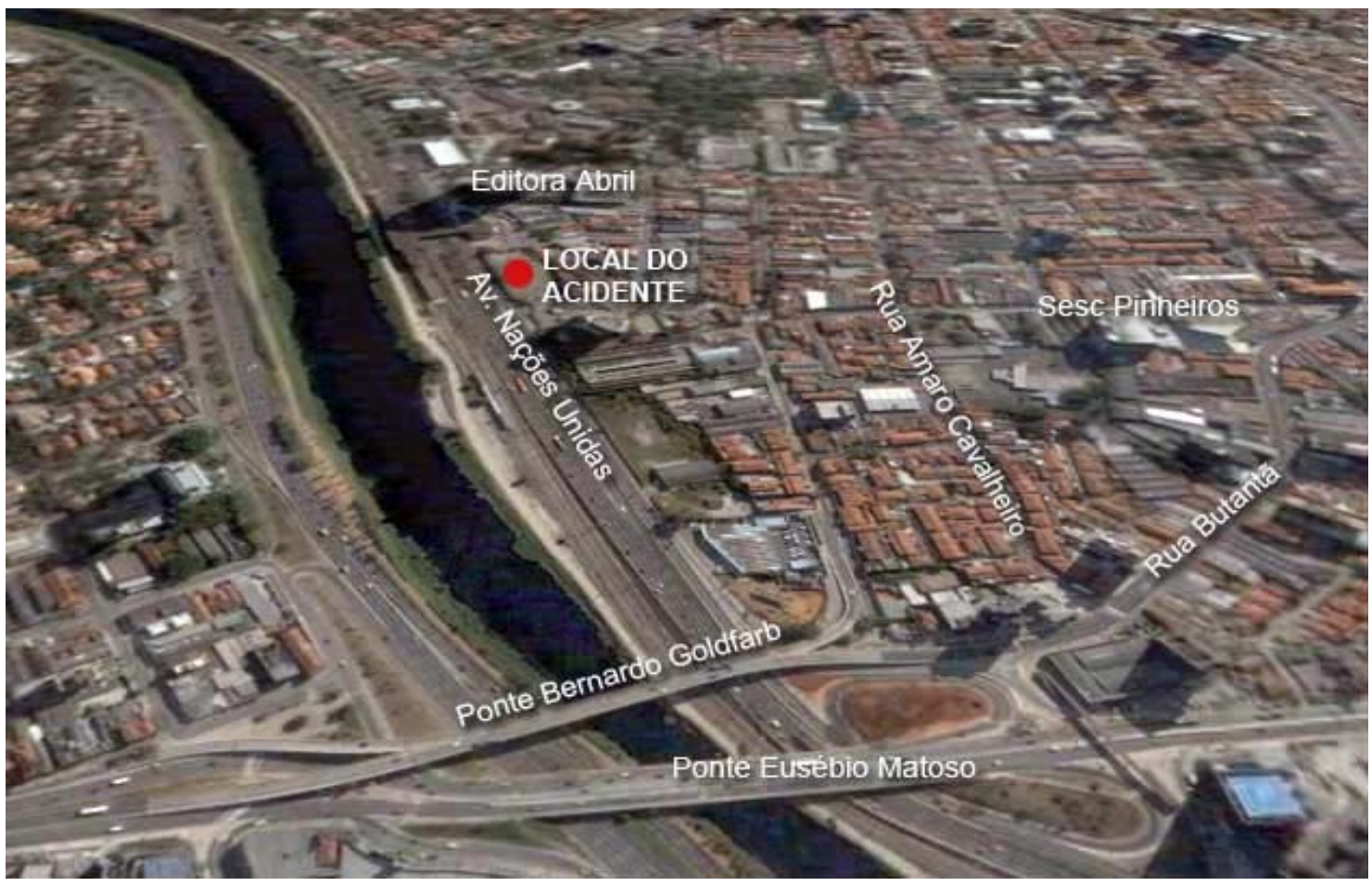

Vista aérea da região atingida pelo desabamento, 2007. Fonte: Folha de São Paulo

Examinando atentamente o ocorrido percebemos que um eixo de circulação em construção interferiu em outras redes organizadas naquele espaço, superpostas, e surpreendendo os cidadãos que se deslocaram, inadvertidamente, para o centro de uma tragédia. Essa superposição de espaços constitui espacialidades diferenciais.

Um micro-ônibus e cidadãos que circulavam naquela área, levados por demandas de suas relações e práticas sociais estabelecidas, atravessaram aquele eixo invisível ignorando os riscos determinados por obra de engenharia, pensada para organizar a vida da cidade. A construção desse eixo acabou articulando tragicamente - também numa dimensão de tempos distintos - um plano do lugar ${ }^{2}$ em que as questões cotidianas se desenvolviam ao plano da metrópole ${ }^{3}$ que buscava organizar a rede de transportes públicos, em nome dos cidadãos.

2 Plano de lugar: expõe a realização da vida humana nos atos do cotidiano, como modo de apropriação que se realiza pelo uso, por meio do corpo (CARLOS, 2001: 12).

3 Plano da metrópole: ilumina a perspectiva do entendimento da cidade como obra humana, materialidade produzida ao longo da história, revelando-se como mediação entre o plano do lugar e o plano do espaço mundial (CARLOS, 2001: 12). O plano do espaço mundial aponta a virtualidade de seu processo de reprodução contínuo. Esses três planos constituem níveis escalares articulados configurando a noção de reprodução da sociedade (ibidem: 130). 
Estes fatos remetem ao texto de Lacoste quando aponta a questão da supressão da formação e construção do raciocínio geográfico como forma de excluir, segundo ele deliberadamente, a possibilidade de apropriação dos espaços àqueles que não tiveram acesso e direito a leitura das cartas, ainda a propósito de exemplificar, que representam em escalas diversas as complexidades desses espaços vividos agora incluindo a construção de um novo fluxo.

A simples descrição ou leitura da paisagem são insuficientes para que se estabeleça um raciocínio geográfico. A carta, representando as espacialidades diferenciais, organiza e sistematiza as informações e dados que permitem conhecer o espaço geograficamente.

Voltemos ao caso em análise. O conjunto espacial representado pelas casas do entorno da estação em construção, revelavam os problemas estruturais da obra. As casas apresentaram rachaduras que evidenciavam problemas. Todavia nenhuma Associação de Moradores, a propósito de usar a imaginação como recurso filosófico e científico, teve acesso as cartas de localização da obra e as informações ali contidas para, antecipadamente, tomar medidas junto ao Judiciário, que impedissem a tragédia.

Podemos levantar a hipótese de que os cidadãos não tinham suficiente formação para agir a partir dos conhecimentos geográficos como teriam feito se um laudo resultante de estudos das diversas áreas técnicas do próprio metrô afirmasse que o risco de movimentação do solo era iminente. Ler sobre isto mobilizaria os indivíduos. O gênero de texto jurídico seria claro para um bom número de cidadãos. A ocultação estratégica de outros textos, entretanto, levaram a uma observação desfocada dos eventos que enunciaram aqueles problemas.

Uma das ocultações estratégicas, que Lacoste refere em sua obra, é a cartográfica a qual os não geógrafos deixam de ter acesso, sobretudo quando se trata de documentos técnicos produzidos pela administração. 
Pode-se inferir que a representação cartográfica daquela região, tomada como um dos parâmetros de planejamento da obra, não revelam a configuração complexa do espaço terrestre do entorno. Portanto deixa-se de considerar outras dimensões das relações sociais ali presentes e estas são postas em risco que, neste caso, materializou-se em tragédia.

Abaixo temos um croqui de localização que traduz justamente essa definição.

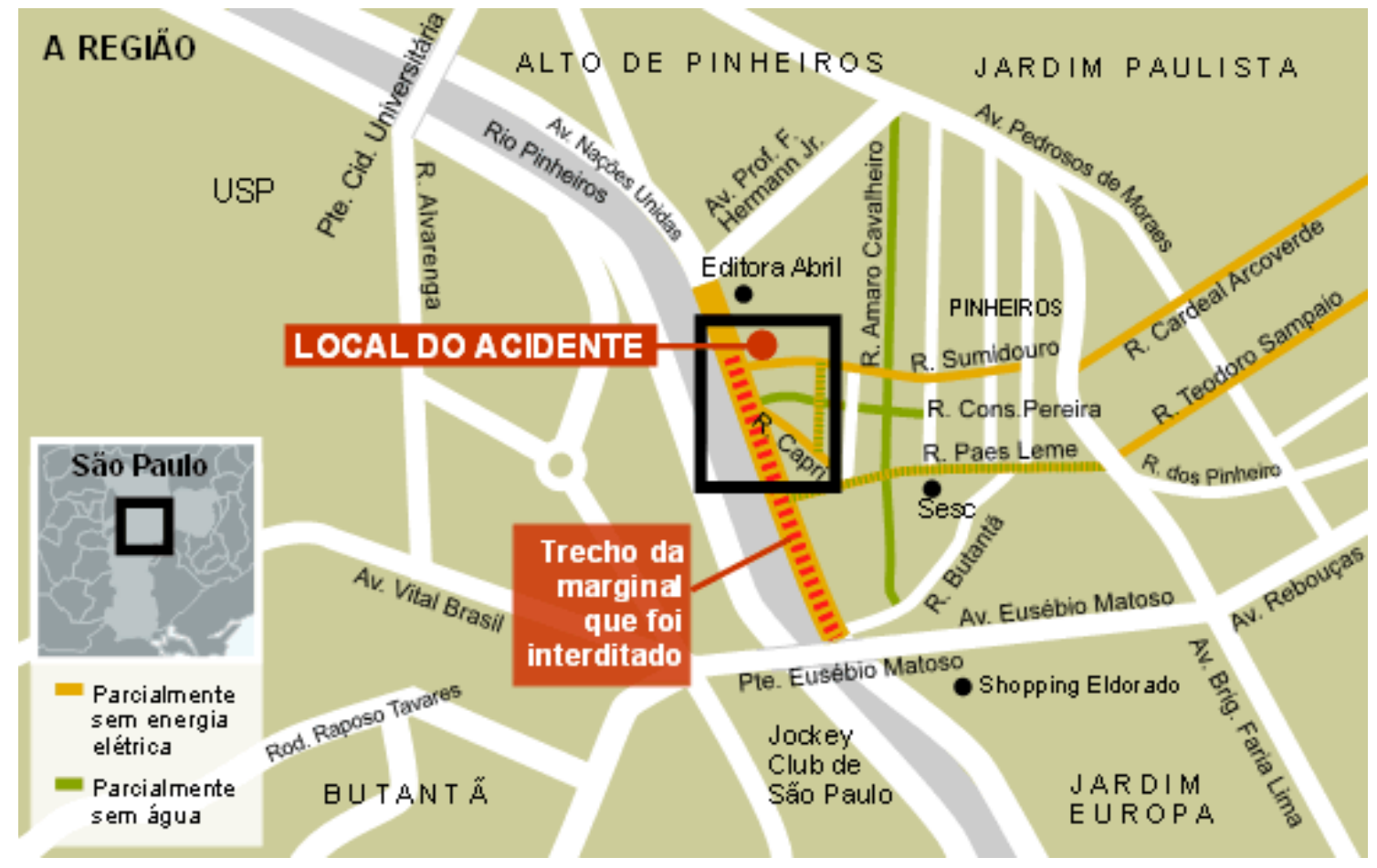

Editoria de Arte/Folha -folha on-line 14/01/2007

Ao tomar a referência da região e representá-la, a mídia dá contornos ao evento que excluem importantes informações sobre os deslocamentos próprios do lugar ${ }^{4}$. As linhas de força econômica não são representadas adequadamente. Os prédios que as representam, ali estão, mas não os eixos de organização da força de trabalho, por exemplo. Enquanto pólo urbano era de se esperar outras representações como o Largo da Batata, importante entroncamento de diversas linhas terminais do transporte público que, inclusive, justificaram a construção da linha de metrô em questão.

4 A definição de lugar, enquanto conceito da Geografia, é aprofundado no capítulo II. 
Ou seja, a administração, a mídia utilizando os recursos do conhecimento geográfico disponível, de certa forma, ocultam dados, informações que permitissem a correta leitura daquele espaço e as complexidades que se mostraram inutilmente em certa dimensão de tempo, anunciando a tragédia que viria ocorrer.

Como vimos em nosso exemplo, a região de Pinheiros estabeleceu intersecções com outras possibilidades espaciais de contornos não coincidentes com aquela região. Essa dimensão precisa ser ensinada.

$$
\begin{aligned}
& \text { O método que permite pensar eficazmente, } \\
& \text { estrategicamente a complexidade do espaço } \\
& \text { terrestre é fundamentada, em grande parte, sobre a } \\
& \text { observação das intersecções dos múltiplos conjuntos } \\
& \text { espaciais que se podem formar e isolar pelo } \\
& \text { raciocínio e pela observação precisa de suas } \\
& \text { configurações cartográficas (LACOSTE, 2006: 68). }
\end{aligned}
$$

É neste ponto que se faz necessário considerar a proposta de Lacoste, que alerta para a necessidade de se garantir, pela desacomodação pedagógica dos professores, acesso aos fundamentos para a compreensão do espaço em sua complexidade, através das possibilidades da Geografia Escolar.

Afirmar os princípios educacionais de formação da cidadania inclui esta reflexão. Sem introduzir novas possibilidades teóricas neste debate, sobretudo pensando a Educação Básica, mantém-se o discurso das finalidades da educação numa esfera que não aponta as condições efetivas de articulação entre os valores e as práticas sociais globais, relevantes para a cidadania ativa.

Foi a partir dessa reflexão que decidi estabelecer as condições para realizar este estudo de caso, redimensionando-o para compreender questões relevantes para a Geografia e a Educação Infantil. No Capítulo I, abordo as questões relativas ao contexto educacional em que ocorrem reformas do ensino, a partir da década de 90, primeiro fundamento para a delimitação do problema que apresento. 
No Capítulo II, apresento as questões relativas ao ensino da Geografia e como conhecimentos desse campo colaboram para os arranjos curriculares dessa etapa de ensino, destacando, então, o Referencial Curricular Nacional para a Educação Infantil.

O Capítulo III traz a fundamentação teórica acerca da aprendizagem e do desenvolvimento da criança. Aí discuto as teorias sócio-históricas a partir do trabalho de Vygotsky, destacando os processos de internalização das funções psicológicas superiores, o papel da mediação nesse âmbito e a importância do papel docente nos processos educativos formais, presentes na Educação Infantil, consideradas as condições objetivas do estudo.

Por fim, o Capítulo IV traz o estudo de caso. Contextualizo a escola em que este se realiza, bem como introduzo aspectos das políticas educacionais do sistema educacional do município de Diadema, ao qual a Escola Serraria pertence. Partindo de uma definição conceitual de croqui, o capítulo se organiza pela discussão dos avanços que as políticas educacionais alcançaram naquele município. Isto implica uma breve apresentação do modelo democrático popular de gestão de governo.

Em seguida aprofundo aspectos relevantes do projeto pedagógico da escola e de como esta vem respondendo aos desafios das diretrizes educacionais destinadas a garantir acesso e permanência das crianças na escola. Ao apresentar a construção dos procedimentos do estudo de caso, apresento também as crianças envolvidas na atividade. Segue-se a esta caracterização a análise dos resultados do estudo de caso. 


\section{CAPITULO I - POLÍTICAS EDUCACIONAIS E REFORMAS DO ENSINO NO BRASIL (1990 - 2000)}

Neste capítulo discuto o impacto das reformas do ensino durante a década de 90, na reorganização da Educação brasileira. É um período crucial para o entendimento das disputas que se travam no campo da educação formal que culmina, em meados dos anos 90, com a edição da Lei de Diretrizes e Bases (Lei no 9394/96, promulgada em 20 de dezembro de 1996).

Tanto as reformas que antecedem a promulgação da legislação como as políticas educacionais que a ela se seguem revelam a intensidade dessas disputas, estabelecidas entre os segmentos que, naquele momento, atribuem a Educação papel central no processo de transição e fortalecimento democráticos. Ou ainda nos processos que reorganizaram a atuação de agentes favoráveis a concepções hegemônicas do desenvolvimento econômico, ancoradas nas iniciativas de valorização e fortalecimento da lógica de mercado, que passaram a considerar a Educação um elemento fundamental de qualificação para o processo produtivo e de consumo.

Compreender esse contexto permite introduzir a reflexão sobre o papel que a Geografia pode desempenhar no âmbito do debate educacional, envolvendo as questões curriculares, didático-metodológicas e de formação docente, num momento em que as referências paradigmáticas, no campo da Educação, estão sendo amplamente questionadas.

Lanço um olhar sobre a perspectiva histórica desse período, trazendo elementos de períodos anteriores quando necessário, e busco compreender a perspectiva política para pensar o ensino e as contribuições da Geografia para a organização curricular da Educação Básica no nível da Educação Infantil. Recorrendo ao Referencial Curricular Nacional para a Educação Infantil (1998), abordo o eixo de trabalho Conhecimento de Mundo - Natureza e Sociedade, para fundamentar a construção das atividades do estudo de caso que desenvolvi. 
Originalmente considerava importante discutir o ensino da Geografia nas séries iniciais tomando a perspectiva da alfabetização cartográfica como referência. Segundo Simielli (1996: 20), a alfabetização cartográfica participa do processo formativo das crianças de séries iniciais, "pois esse é o momento em que o aluno inicia-se nos elementos da representação gráfica para que posteriormente possa trabalhar efetivamente com a representação cartográfica".

A proposta que Simielli desenvolveu através de sua obra Primeiros Mapas: como entender e construir (1993) considera a necessidade de se alfabetizar cartograficamente como a possibilidade "de se educar o aluno para a visão cartográfica", como posteriormente aponta a própria autora (SIMIELLI, 1996: 23).

A grande contribuição de Simielli, nesse momento, diz respeito a se "considerar o interesse natural da criança pela imagem". No âmbito deste estudo, vou defender que podemos compreender esse interesse natural, sobretudo, como interesse construído histórica e culturalmente.

A espacialidade das crianças, nas séries iniciais, poderia ser trabalhada segundo o lugar de sua vivência cotidiana - a escola, o bairro, a cidade buscando, através das representações gráficas, desenvolver as noções de: visão oblíqua; imagem tridimensional e bidimensional; o alfabeto cartográfico (o ponto, a linha, a área); construção da noção de legenda; proporção e escala; lateralidade, referências e orientação espacial.

A rigor o desenvolvimento dessas noções através dos conteúdos da Geografia (vamos entender aqui que na escola a Cartografia pertence a esse campo de saber escolar) pode representar as possibilidades de superação da situação didático-pedagógica que submeteu a Geografia escolar, ao âmbito das disciplinas dependentes dos processos de memorização.

A alfabetização cartográfica trouxe a possibilidade de se estabelecer finalidades para o ensino da Geografia reorganizando as condições do seu ensino, a saber: 
1. Aprender a olhar - visão oblíqua e vertical. Através da visão oblíqua, a criança é capaz de reconhecer os elementos, pois eles ficam com volume; já a visão vertical nos mostra os elementos em um plano, de onde só podemos extrair informações bidimensionais.

\section{Complexidade crescente dos conteúdos.}

3. Recursos visuais. Utilização de recursos variados apoiados em imagens diversas, de produtos cartográficos elaborados, de processos de elaboração de mapas para a formação de um aluno mapeador consciente para desenvolvimento das capacidades de leitura e crítica da criança (SIMIELLI, 1996: 25-29).

Em vista desses avanços levantei a hipótese de trabalhar no âmbito da formação de um aluno, leitor crítico, das representações cartográficas. Esse objetivo, essencial para o ensino da Geografia, impunha uma profunda reflexão sobre as relações de ensino no âmbito da sala de aula, o que localizava minha questão no campo didático.

Ensinar a Geografia através das representações gráficas, para alcançar a possibilidade do trabalho com as representações cartográficas, nas séries iniciais, exigia a produção de material relevante destinado a leitura e interpretação de representações gráficas, através de croqui de localizações, por exemplo.

Esse conjunto de aspectos, envolvidos em minha reflexão inicial, indicou uma nova questão: seria mesmo a partir das séries iniciais que se ensina a Geografia? É somente a partir daí que as crianças têm acesso as representações gráficas, aos mapas, aos conceitos próprios do raciocínio geográfico?

Transformei minhas indagações numa questão que acabou por redimensionar todo o trabalho. Decidi considerar as contribuições da Geografia para o ensino na Educação Básica, mas considerando a Educação Infantil como a etapa que 
poderia incorporar essas contribuições, considerando as representações gráficas conteúdos relevantes para o trabalho com o eixo Conhecimento de Mundo, já indicado acima.

A partir dessa retomada tomei os Referencias Curriculares para a Educação Infantil (1998) como dimensão das políticas educacionais, decorrentes do período estudado, e como objeto de estudo para a identificação e verticalização dos eixos curriculares dos quais participa a Geografia, quando falamos de matrizes curriculares desse nível de ensino.

Para compreender o sentido dessa decisão é necessário discutir o período histórico e contexto político daquela década e os fatos relevantes que o marcaram, o que incluiu a promulgação da legislação destinada a estabelecer as diretrizes e bases da Educação nacional.

\section{A construção da Educação Básica no Brasil: incluindo a Educação Infantil}

Há inúmeros estudos, pesquisas, ensaios, artigos produzidos nos últimos dez anos destinados a pensar, problematizar, questionar a Lei de Diretrizes e Bases da Educação Nacional, promulgada em 1996. Não é objetivo deste capítulo aprofundar a discussão sobre o papel da LDB na reorganização do sistema de ensino ou sua finalidade, considerando os aspectos que regulamenta.

Todavia não é possível pensar as questões de ensino a que me proponho nesta pesquisa, sem referir a legislação. Aqui eu o faço tomando um aspecto que considero relevante, central, mas pouco focado até o momento, quando se pensa a perspectiva histórica e política que marca o campo educacional em transformação, com ênfase no contexto da década de 90.

Trata-se da discussão sobre a organização da Educação Nacional com base no grande ciclo denominado Educação Básica. A lei determina a organização do sistema de ensino desde a Educação Infantil, Ensino fundamental e Ensino Médio. Desta forma um ciclo considerado essencial a formação de crianças e jovens é organizado para atender a Educação Básica de 0 a 18 anos. 
Quero aprofundar minhas reflexões acerca da idéia de organização da Educação Básica, que considero um avanço. No âmbito do sistema de ensino, a idéia de que a formação da criança se dá num continuum está pressuposta pelos níveis de ensino como períodos formativos que deveriam se articular em função de princípios e finalidades que, afinal, são norteadores de toda a Educação Nacional.

Na prática ainda não há uma regularidade na articulação dos processos formativos desde a Educação Infantil, que pudesse resultar em sua avaliação considerando-o como um grande e único ciclo. Somente o Ensino Fundamental é obrigatório. Os sistemas de ensino ${ }^{5}$, organizados em nível municipal, estadual e federal, podem flexibilizar sua organização quanto aos níveis que não sejam prioritariamente da sua responsabilidade oferecer. Isto significa que o sistema de ensino no país está obrigado a oferecer tão somente o Ensino Fundamental e quando se estabelecem os indicadores de avaliação do sistema este é o objeto central de atenção.

A flexibilização que a lei permite acaba facultando ao Estado que ofereça o nível obrigatório, hierarquizando níveis de atendimento dentro da Educação Básica, segundo a disponibilidade de financiamento e investimento. O próprio FUNDEF indicava essa tendência. Parece haver nova possibilidade de arranjos nessa área na medida em que o FUNDEB $^{6}$, que retoma os níveis de abrangência dos investimentos em educação, está voltado para o conjunto da Educação Básica.

Aspectos da formação social e da história da Educação em nosso país é que levaram a essa organização fragmentada, atendendo às necessidades educativas de jovens e crianças, de forma espasmódica e reativa a demandas e pressões sociais ${ }^{7}$ quando já não são passíveis de controle.

Conforme o artigo $4^{\circ}$ da LDB, que define os deveres do Estado com a educação.

O Fundeb terá vigência de 14 anos, a partir do primeiro ano da sua implantação, que se dará de forma gradual em três anos, quando então estará plenamente implantado, com $20 \%$ das receitas de impostos e transferências dos Estados e Municípios (cerca de R\$ 51 bilhões) e de uma parcela de complementação da União (cerca de $\mathrm{R} \$ 5$ bilhões). O universo de beneficiários do Fundeb é da ordem de 48 milhões de alunos da Educação Básica. Difere do Fundef, inclusive por estar destinado à Educação Infantil, ao Ensino Fundamental e ao Médio.

7 Lembro os fatores que explicam a ampliação da educação primária e da Educação Infantil, ambas definidas em função do modelo econômico e dos processos de urbanização que levaram as mães a lutar por mais escolas, enquanto foram agregando-se ao mercado de trabalho. 
A escola, então, se organiza para formar a infância e juventude na Educação Básica, cumprindo os objetivos que estão propostos/impostos a ela. O sistemas de ensino atendem ou a Educação Infantil, ou o Ensino Fundamental - ainda ouço primário e ginásio para indicar o Ensino Fundamental como se durante 25 anos as escolas não tivessem sido organizadas por graus, $1^{\circ}$ e $2^{\circ}$ - ou o Ensino Médio.

Esse exemplo da referência primário/ ginásio revela que não basta a legislação prescrever os elementos de uma reforma e de mudanças no sistema de ensino. No contexto histórico as relações sociais, as tensões e enfrentamentos das classes sociais e os antagonismos entre elas vão determinar o quadro de forças que será capaz de "influenciar" o processo de decisão provocando ou não as mudanças.

Toda uma geração de crianças das classes populares, em formação a partir da década de 60, beneficiou-se da LDB de 61, que pela primeira vez organizou as diretrizes para a Educação Nacional. Tal legislação, embora reivindicada desde as primeiras ações do escolanovismo ${ }^{8}$, efetivou-se num momento histórico marcado pelo crescimento das populações urbanas que pressionaram por mais escolas.

Se até o início da década de 60 fazer o Grupo Escolar era suficiente, a partir daí um conjunto de fatores relacionados ao processo de urbanização e industrialização ${ }^{9}$ foram ampliando as exigências para os níveis de formação da população e das novas gerações. As tensões sociais estavam presentes nesse momento.

8 O escolanovismo desenvolveu-se no Brasil no momento em que o país sofria importantes mudanças econômicas, políticas e sociais. O acelerado processo de urbanização e a expansão da cultura cafeeira trouxeram o progresso industrial e econômico para o país, porém, com eles surgiram graves conflitos de ordem política e social, acarretando assim uma transformação significativa da mentalidade intelectual brasileira. No cerne da expansão do pensamento liberal no Brasil, propagou-se o ideário escolanovista (GALLO, 2001 - anais da anped - 24ª reunião anual)

9 O início da industrialização entendida aqui como traço da sociedade contemporânea, como principal atividade econômica e forma através da qual a sociedade se apropriava da natureza e a transformava, marcou e revolucionou profundamente o próprio processo de urbanização. Urbanização, processo que remonta à Antiguidade, em que a cidade é um fato desde que determinadas condições históricas, o permitiram há cerca de 5.500 anos atrás, na Mesopotâmia. Dado o caráter urbano da produção industrial (produção essa totalmente diferenciada das atividades produtivas que se desenvolvem de forma extensiva no campo, como a agricultura e a pecuária) as cidades se tornaram sua base territorial, já que nelas se concentram o capital e força de trabalho. 
A legislação de 61 vai criando as condições para certa consolidação do sistema de ensino e grandes contingentes populacionais chegam à escola pública. Esta passa a funcionar como unidade de um grande sistema. É a partir daí que a pesquisa educacional se consolida. Passa a fazer sentido pensar em ensino, currículo, aprendizagem e conhecimento escolar, como dimensões decorrentes das complexidades do desenvolvimento social, econômico e político do país, bem como da cultura.

Penso que as políticas educacionais no Brasil têm sido propostas para atenuar efeitos e emergências e riscos provocados pelos projetos políticos hegemônicos. Estudando mais detidamente a legislação educacional vemos que esta sempre reverte para ações paliativas, de controle, que se tornam insuficientes para alicerçar um Sistema Educacional Brasileiro. Quando muito temos construído um frágil sistema de ensino a partir de necessidades conjunturais definidas por uma lógica política, no sentido daquela disputa entre projetos, que referi anteriormente.

Meu esforço vai no sentido de pensar, tomando o recorte histórico do processo de urbanização decorrente da implantação de um modelo econômico baseado no desenvolvimento industrial - nos anos sessenta - como o momento em que a entrada da mulher no mercado de trabalho torna-se fator decisivo na provocação de mudanças do contexto social, a partir da organização familiar, materializando-se em lutas por mais escola e creches.

Esse processo que altera as condições da organização familiar, provoca a discussão sobre $\mathrm{o}$ atendimento a crianças em idade pré-escolar ${ }^{10}$ e as muito pequenas ${ }^{11}$. Historicamente este atendimento esteve organizado através das instituições de caridade e suas creches, no campo da assistência social. A população urbana que consolida sua presença nas cidades vai exigir, a partir da década de 70 , a pré-escola e as creches para as crianças. Esta é uma reivindicação para toda uma população, e a filantropia não poderá responder a tal demanda.

${ }^{10}$ Criança pré-escolar: até a promulgação da LDB, em 1996, referia-se à criança atendida nas pré-escolas, entre os 4 e 6 anos de idade.

11 Criança pequena: as creches sempre atenderam a crianças entre 0 e 3 anos. Com a definição de creche como instituição de ensino, criança pequena passa a designar a criança de 0 a 6 anos atendida nas instituições de ensino da Educação Infantil. 


\section{Uma Educação que se construiu a partir de cima}

A organização da Educação Básica deve ser pensada a partir de suas raízes históricas, para compreendermos como a criança foi adentrando a escola. A Educação no Brasil se fez através dos Jesuítas, vindos as novas terras para tomar parte do processo de colonização, organizando uma Educação destinada a evangelização e a preparação de filhos da elite, para prosseguimento de estudos na Europa.

Com a expulsão dos jesuítas por decisão do Marques de Pombal (século XVIII) surgem iniciativas destinadas a formação dos quadros de que necessitava a coroa portuguesa iniciando uma tradição de se educar através de uma escola ${ }^{12}$ útil aos interesses do Estado. Nesse modelo, concebido pelo círculo de Pombal, a instrução elementar destinada ao povo não era uma preocupação, menos ainda uma prioridade. Somente com a independência surge certa iniciativa política no campo da instrução popular, impulsionada pela conjuntura política favorável as idéias democráticas pós-independência:

O documento oferecido pelo Andrada, embora vazado por uma linguagem que ainda fazia concessões ao regime absolutista então vigente, apoiando-se basicamente nos escritos de Condorcet, clama pela difusão da instrução nas camadas populares e pela organização de um sistema de ensino a cujos diferentes níveis pudessem aceder todos os cidadãos na exclusiva medida de suas capacidades. (HAIDAR, 2002: 61)

Mesmo emergindo a idéia de um sistema de ensino, com base nas concepções liberais, ainda assim a instrução pública foi escassa em território nacional nesse período que se segue a Independência. Com a Proclamação da República a tarefa de se implementar políticas educacionais, agora se observando o princípio federativo, não avançou significativamente,

12 Criando-se cursos de formação nas áreas da defesa, da medicina, comércio, agricultura, química, desenho técnico, direito. 
permanecendo a partilha de atribuições para o oferecimento de Educação, herdada do império, praticamente sem alteração, ou seja, mais centradas nos estados que na União.

Entretanto com as alterações políticas e econômicas ocorridas a partir de 30 (Governo Vargas) surgem os elementos que vão resultar num intenso processo de industrialização, crescimento urbano e migração campo-cidade. Isto afeta a constituição das classes que compunham a elite brasileira de natureza agrária, agregando-se a elas novos segmentos oriundos do campo empresarial industrial.

Nesse contexto é que a população urbana, agora almejando chegar a melhores condições de vida, pressiona por ampliação das condições de acesso a educação. Este aspecto da história da educação nos interessa por dois motivos: primeiro porque podemos afirmar que a ampliação e a organização do sistema educacional brasileiro deriva da pressão popular por acesso. Educação era essencial naquele contexto de desenvolvimento. Segundo porque as alterações impostas às grandes oligarquias que procuravam atender a demandas por serviços públicos em geral, regionalmente, deslocou para o estado o papel de responder a necessidade de organizar, efetivamente, o sistema de ensino.

No final do Estado Novo surgem as primeiras ações normativas da União sobre a Educação. Um fato relevante desse período é a criação do Fundo Nacional do Ensino Primário. Nesse período as modalidades de ensino passaram a se articular com a emergente escola primária. Essas modalidades eram destinadas à formação técnica, a formação docente e ao ensino universitário desde que no mesmo campo destinado a atuação profissional.

O Ensino propriamente secundário era destinado a formação, segundo a legislação da época, a futuras lideranças dirigentes às quais cabia uma sólida formação de cultura geral já que iriam assumir a direção do país. 
A partir de 1945 a escola primária de quatro anos vai-se firmando progressivamente como escola básica e única e constitui o primeiro processo de escolarização. Nesse nível de ensino observam-se as idéias da escola nova, com forte ênfase numa abordagem das necessidades biopsicológicas da criança, adequação curricular, organização do ensino por programas, a adoção de metodologias especificas para o ensino.

Uma contradição se estabeleceu nesse momento de ampliação do sistema de ensino. Se por um lado a Educação se tornava obrigatória, o que levou grandes contingentes populares para a escola pública, por outro, do ponto de vista das concepções da Educação decorrentes da escola nova, firmaram-se as idéias hegemônicas e dominantes reveladoras de um otimismo pedagógico ${ }^{13}$ que acabou se materializando em metodologias e programas que excluíram as condições de permanência dos grandes contingentes proletários na escola. As lutas populares conquistaram a ampliação do sistema de ensino, mas a normatização pedagógica gerou dificuldades no processo ensinoaprendizagem, provocando um processo de exclusão de grandes contingentes populares da escola, através do modelo pedagógico desfavorável a essa população.

Se a burguesia muito se favoreceu da energia das classes populares em luta incorporando a reivindicação por mais escolas no início do século passado, abandonou-as quando decidiu que o processo educativo deveria ser qualificado com base nos aparatos tecnológicos, didáticos, metodológicos. Assim passouse a um momento histórico em que o ensino baseado na concepção tecnicista, bastante coerente com as necessidades definidas pela expansão do modelo econômico industrial, acabou por tornar a escola pública o espaço de formação das classes mais abastadas e da emergente classe média. Portanto a escola pública de qualidade da década de 60 não era uma escola para todos.

13 Conforme Nagle (apud SAVIANI, 1994, 62), o otimismo pedagógico acredita que as coisas vão bem e se resolvem nesse plano interno das técnicas pedagógicas. Há uma transmissão da preocupação dos objetivos e conteúdos para os métodos e da quantidade para a qualidade, abandonando-se a perspectiva da participação popular que unira a burguesia urbana ao proletariado a partir da década de 10, do século XX. 
Grandes contingentes populares, proletários, todavia, cursavam as quatro primeiras séries, abandonando a escola após esse período de estudos, marcado por dificuldades e fracassos das crianças oriundas das classes operárias urbanas e das colônias rurais, freqüentando a escola rural.

Subjacente a essas reivindicações, estiveram sempre presentes as questões relacionadas a adequadas condições de investimento na esfera educacional, condição essencial para materializar os processos de democratização de acesso, que poderiam significar aos amplos segmentos populares as condições de permanência na escola. Os investimentos é que asseguram a qualidade social da educação através da formação docente, infra-estrutura, material e recursos didáticos.

A legislação de 1971 (lei 5.692) trará para o âmbito da organização do sistema a idéia de uma formação obrigatória em 8 anos o que passará a ser considerado $o$ fundamental como $1^{\circ}$ Grau. A obrigatoriedade do $2^{\circ}$ Grau será flexibilizada.

Somente em 1996 é que se avança a idéia de uma Educação Básica proposta para atendimento de crianças a partir de zero anos de idade, organizando-se então a Educação Infantil. E é essa nova forma de organização da Educação que considero essencial para os pressupostos desta pesquisa, quando busco compreender as questões curriculares pensadas para essa etapa da Educação Básica.

A constituição de 1988 estabelece garantias constitucionais em torno de direitos sociais, o que incluiu as políticas públicas educacionais. A Educação constitui um campo capaz de contribuir para o fortalecimento das conquistas sociais, para a consolidação e transição democrática, para os avanços no desenvolvimento social e econômico do país.

O grande instrumento consagrador de tais mudanças foi a constituição de 1988. Esta não foi uma outorga. Foi fruto de lutas e lobbies, de diferentes tendências e setores organizados da sociedade civil e política. A Constituição e seus instrumentos sucedâneos 


\section{geraram e demarcaram novos espaços e novas \\ formas de agir dos grupos organizados (GOHN, \\ Movimentos Sociais e Educação, 99)}

Toda a expectativa de desenvolvimento social e econômico que se colocou em relação à Educação, nesse momento, acabaram se transformando em tensão e confronto. A retomada do processo democrático levou as forças econômicas dominantes a buscar um modelo que representasse a oportunidade de inserção no que se convencionou chamar, então, de uma nova ordem mundial, decorrente da ação hegemônica dos países de centro que determinaram o Consenso de Washington como norteador das ações e medidas no campo econômico.

Aqui não se trata de fazer esse debate. Mas apontar que essas demandas determinaram que a Educação teria, a partir daí, papel fundamental para garantir aos países considerados então emergentes, as condições para essa inserção.

Esses segmentos atribuíram a Educação o papel de preparar as novas gerações para a atuação num mercado que vinha sendo tocado pela necessidade de absorver trabalhadores capacitados segundo novas demandas, sobretudo tecnológicas. Aí se inscrevem as mudanças requeridas no campo da Educação, por esses segmentos, e esses fatores definiram a edição de um conjunto de reformas no âmbito do sistema de ensino, que marcaram a década de 90.

Tais reformas foram objeto de profundas disputas entre os diversos setores que apresentaram projetos distintos no campo educacional. Se por um lado a Educação era considerada fator de desenvolvimento e inserção do país nessa agenda, por outro, como projeto emancipatório ${ }^{14}$ dos segmentos populares (herdado das lutas dos anos 80) constituía o centro de interesses de movimentos sociais, de diversos e distintos segmentos organizados da sociedade civil, dos trabalhadores na Educação, dos pesquisadores da esfera acadêmica.

${ }^{14} \mathrm{O}$ conceito de emancipação, que dá base à idéia de projeto emancipatório, deriva do latim emancipare, relacionado-se ao processo, individual e coletivo, de considerar pessoas ou grupos independentes e representa o processo histórico, ideológico, educativo e formativo de emancipar indivíduos, grupos sociais e países da tutela política, econômica, cultural ou ideológica (PIZZI, 2005). 
A edição da LDB acabou refletindo os níveis de diálogo e confronto exigidos para aquele momento histórico entre as diversas forças que atuavam no campo educacional.

A "construção" da LDB, mesmo considerando o antagonismo entre diversas concepções de Educação, sua finalidade, seu papel, estabeleceram certo consenso em torno da idéia da centralidade da Educação, incluídos os aspectos políticos, econômicos, sociais, culturais mobilizados em torno do projeto de democratização, em sua etapa pós-ditadura. Em momentos de grande disputa como esse era importante manter a clareza sobre a natureza pública a ser preservada na escola, conforme a reflexão de Rodrigues:

Ela [a escola] tem de ser protegida contra todo esforço de apossamento de sua competência, por parte de qualquer grupo que a queira aliada de seus interesses particulares. Por conseguinte, a escola não pode pertencer a nenhuma camada social privilegiada, mas há de ser pública na sua constituição, organização e na escolha de seus fins. (RODRIGUES, 2000: 55).

Não podemos afirmar que as reformas do início da década de 90 preservaram a escola do risco do apossamento indicado por Rodrigues. O país ainda está às voltas com a década de implantação da LDB. Os avanços ocorreram no plano da organização da Educação Básica, da quebra de paradigmas que representou, mas por ora os indicadores de que se dispõe revelam sucessivas perdas no âmbito da formação dos jovens egressos do sistema de ensino ${ }^{15}$ sobretudo quando se constata que enfrentam dificuldades para ler,

15 No Brasil, o Índice de Desenvolvimento da Educação Básica (IDEB) é calculado a partir da combinação de informações de desempenho em exames padronizados (SAEB, Prova Brasil) ao final da $4^{\mathrm{a}}$ e da $8^{\mathrm{a}}$ séries do Ensino Fundamental e do $3^{\circ}$ ano do Ensino Médio. No Brasil, a escola pública no Ensino Fundamental alcançou uma média de 3,8 nas séries iniciais e 3,5 na segunda fase. No Ensino Médio, a média foi de 3,5. São índices baixos, que revelam as dificuldades da educação formal no país. Entretanto, Diadema, a cidade onde ocorre o estudo de caso, a média alcançada na Rede Municipal de Ensino foi de 4,8 nas séries inicias. A meta que o MEC estabeleceu para superar tal situação é de alcançar média 6,0 até 2021. Fonte: http://ideb.inep.gov.br 
interpretar, escrever, calcular, tendo assim comprometidas as condições de acesso à cidadania, apossados de seus projetos e sonhos.

Mesmo havendo a garantia legal de se garantir a organização da escola com base na gestão democrática para efetivar sua proposta educacional este paradigma não se implementou, mesmo considerando a idéia de Saviani (1994) de que não há oposição a idéia da participação na gestão da escola. Todavia é importante lembrar que não se constroem relações e gestão democráticas dentro das escolas se determinadas condições objetivas estão ausentes, no âmbito das relações sociais:

Considerando-se, como já se explicitou, que, dado o caráter da Educação como mediação no seio da prática social global, a relação pedagógica tem na prática social o seu ponto de partida e seu ponto de chegada, resulta inevitável concluir que o critério para se aferir o grau de democratização atingido no interior das escolas deve ser buscado na prática social. (SAVIANI, 1994: 86).

$\mathrm{Na}$ escola, mesmo com a atribuição dos Conselhos de articular as forças envolvidas com a atividade educacional, a partir da autonomia relativa que a caracteriza, a ação destes tem sido insuficiente para alterar as práticas educativas transformando a administração num processo de gestão democrática.

A formação de jovens e crianças expressa as dificuldades em se implementar a efetiva democratização da escola, pela via da construção do conhecimento, quando se constata que as crianças vivem situações de aprendizagem marcadas por sucessivos fracassos.

Para Saviani (1994: 86), "as relações democráticas internas a escola não são condição suficiente de democratização da sociedade", como parece ficar sugerido nos discursos do que vou chamar de otimismo da gestão democrática, 
que, per se, não podem assegurar mais qualidade social a Educação sem que o processo democrático se consolide no âmbito das práticas sociais. Infiro dessa afirmação que a democratização da sociedade, isto sim, é condição para a democratização da escola.

São recentes as mudanças que trouxeram novas forças ao centro do poder, oriundas do campo democrático popular. Não ignoro que estes fatos poderão redefinir as relações e práticas sociais, democratizando-as, com as conseqüências benéficas que esperamos para a escola, de maior participação, de ampla inclusão dos setores populares. Porém, ainda não são perceptíveis as reciprocidades entre mais democracia no jogo político, na sociedade e, portanto, na escola.

Não se pode, entretanto, ficar diante das dificuldades que a escola enfrenta tanto quanto o sistema de ensino, sem buscar alternativas que permitam debater o papel e a função social da escola, a partir desse quadro de dificuldades. Não tem cabimento insistir em defender uma escola publica de qualidade que ficou no passado e que não respondeu as necessidades de formação dos grandes contingentes da população, que envelheceu e que não cabe no quadro atual ou ficar diante desse quadro inerte.

Também não é possível insistir em usar um discurso baseado na idéia de participação, mas construir um eixo de práticas educativas baseadas nas concepções psicopedagógicas que secundarizam a importância dos conteúdos e o processo de construção do conhecimento, fundamento do processo educativo.

Tanto a prática educativa quanto à organização de matrizes curriculares exigem uma tomada de posição na dimensão política que encerram. Estas duas dimensões se imbricam: a educativa e a política:

Uma análise, ainda que superficial, do fenômeno educativo nos revela que, diferentemente da prática política, a educação configura uma relação que se trava entre não antagônicos. É pressuposto de toda 
e qualquer relação educativa que o educador está a serviço dos interesses do educando. Nenhuma prática educativa pode se instaurar sem este suposto. (SAVIANI, 1994: 92)

Desde a Educação Infantil é importante compreender as propriedades da prática educativa que envolvem a persuasão (o consenso, a compreensão). ${ }^{16}$

As contribuições das ciências ao ensino escolar podem alimentar de horizontes ${ }^{17}$ a prática educativa que se distingue da prática política. Na relação entre docente e aluno nenhum antagonismo próprio da dimensão política, cuja prática se firma pela dissuasão e pelo dissenso, pode estar presente. Se estiver, deve ser prontamente abordada desde um ponto de vista crítico, com vista à sua superação.

Para exemplificar: é comum, hoje, os professores conviverem nas escolas com os filhos, sobrinhos e parentes de membros do crime organizado nas chamadas periferias urbanas. As tensões que se estabelecem nessas comunidades envolvem a escola, o professor, a gestão, as famílias e a autoridade que deveriam representar. A ausência de políticas públicas nessas comunidades abandona a população e a escola à dinâmica dessas tensões.

Os confrontos que emergem dessa condição acabam antagonizando docentes/alunos, docentes/gestão, gestão/docentes/alunos/comunidade. Enfrentar prontamente esta como questão central na organização das práticas educativas é atribuição e papel dos educadores.

Creio que um dos equívocos que nos tem acometido no âmbito do exercício profissional tem sido este de tomar o aluno como o outro com quem me indisponho a propósito das diferenças de ponto de vista que formamos pela prática social, o que inclui a família e a comunidade. Isto esvazia o papel da Educação.

${ }^{16}$ Conforme o corolário, a educação é, assim, uma relação de hegemonia alicerçada, pois, na persuasão (consenso, compreensão) da tese 6 , segundo a qual a especificidade da prática educativa se define pelo caráter de uma relação que se trava entre contrários nãoantagônicos. (SAVIANI, 1994: 99).

17 Expressão emprestada da canção "Amor de índio", de Beto Guedes e Ronaldo Bastos. 
Uma possibilidade que pode representar a democratização das relações sociais na escola passa por uma reelaboração da agenda do trabalho docente, que deve incluir os procedimentos de análise dos problemas das crianças, que envolvam aprendizado e desenvolvimento. Outra possibilidade é a elaboração de projetos de intervenção apropriados àquela escola e aquela comunidade, o que não pode excluir a intervenção colaborativa das famílias e da comunidade em forma de subsídios para a construção de práticas educativas relevantes.

É possível compreender que há disputa política nas estruturas do Estado para fazer prevalecer as posições políticas dos projetos e programas educativos em disputa. O fundamental é que as práticas educativas se orientem pelo princípio de defesa do direito da criança e do jovem a uma educação de qualidade social, confrontando pela via do debate educacional, do qual a escola participa mas ao qual não comparece, projetos e programas inadequados, inconsistentes ou incoerentes com a proposta educacional de cada escola.

A construção de consensos possíveis marca a lógica do Estado de direito e as leis daí decorrentes devem ser observadas, lembradas, tomadas como parâmetro, obedecidas. A dimensão da Educação enquanto direito torna-se necessária na medida em que para a escola convergem de modo diverso e desigual crianças que vivenciam as complexidades sociais e seus antagonismos.

Esse direito só é efetivamente assegurado se o acesso ao campo do conhecimento, expressão definitiva da inserção no mundo da cultura, da ciência, da arte estão garantidos pelas práticas educativas decorrentes da proposta educacional da escola e pela intervenção do professor. Esta perspectiva esclarece a importância e o lugar dos "conteúdos" no âmbito das práticas pedagógicas.

Tomo o currículo, hoje, como um documento de identidade ${ }^{18}$ da escola. Reconheço a possibilidade de compreendê-lo para além das limitações

18 Currículo é lugar, espaço, território. O currículo é relação de poder. O currículo é trajetória, viagem, percurso. O currículo é autobiografia, nossa vida, curriculum vitae: no currículo se forja nossa identidade. O currículo é texto, discurso, documento. O currículo é documento de identidade. (SILVA, 2002). 
conteudistas. Considero inadequadas, porém, as posições que, equivocadamente, procuraram impor ao professor, na sala da aula, a idéia da supressão do conteúdo, substituindo-o, as vezes completamente, por um repertório flexível advindo das práticas sociais, como se a cultura e os saberes escolares não pertencessem igualmente a esse âmbito.

Cada eixo temático, na Educação Infantil, vincula-se a práticas sociais globais estando em condições de esclarecê-las, decifrá-las, contextualizá-las revelando seus sentidos e lógicas. Melhor dizendo, através de Saviani, afirmo "que tal contribuição se consubstancia na instrumentalização, isto é, nas ferramentas de caráter histórico, matemático, geográfico, científico, literário etc, cuja apropriação o professor seja capaz de garantir a seu aluno" (1994: 89).

E essa garantia, que se efetiva através da prática educativa, poderá significar para o aluno a oportunidade objetiva de colocar-se, desde o processo formativo, como cidadão crítico das práticas sociais globais das quais participa e as quais produz.

Insisto neste ponto porque via de regra tem-se a tendência a se desvincular os conteúdos específicos de cada disciplina das finalidades sociais mais amplas. Então, ou se pensa que os conteúdos valem por si mesmos sem necessidade de referi-los à prática social em que se inserem, ou se acredita que os conteúdos específicos não têm importância. (SAVIANI, 1994: 89)

A partir daqui quero remeter esta discussão às considerações, justamente, sobre a oportunidade de se propor parâmetros curriculares como uma dimensão das políticas públicas, lembrando que os Parâmetros Curriculares no Brasil envolveram sujeitos e atores sociais, no contexto educacional, representando um esforço de definição de diretrizes para a ação e que construíram aqueles documentos a partir de consensos possíveis. 
Cada escola pode organizar sua matriz curricular respeitando o processo social, que se realiza no espaço de cada uma delas. Há uma complexidade que envolve o debate sobre currículo, a partir de múltiplas teorias, que não serão aprofundados. Tomo desse campo, entretanto, as considerações seguintes:

A relação com os demais campos precisa, portanto, se fazer na interação entre o domínio e a subordinação, na qual o pesquisador em currículo apropria-se daquilo que the é útil em outros campos, tendo, no entanto, a idéia de confrontação criativa. Nessa perspectiva, o encontro entre os diversos fluxos de significados pode ser produtivo para o campo do currículo, na medida em que os pesquisadores consigam, por meio do movimento sem respeito às divisões tradicionalmente estabelecidas entre as áreas de saber, revalorizar as discussões sobre currículo, aproveitando melhor os elementos disponíveis em seu campo de origem. (LOPES \& MACEDO, 2002: 50)

Por ora esta dimensão do currículo, que não constitui uma definição, é suficiente para refletir sobre as condições do fazer curricular. Se se pode sugerir ao pesquisador que procure nova relação com os campos que permitam confrontar criativamente as idéias de diversos fluxos destinados a construção curricular, valorizando as discussões sobre o tema, creio que se pode propor o mesmo a escola buscando articular os fazeres e saberes dos dois âmbitos em favor das práticas educativas e as disciplinas e áreas do conhecimento da esfera escolar.

Tomando a Geografia como foco, nessa discussão, interessa compreender, olhando a partir da escola e não a partir da Universidade, o que se pode esperar quanto ao ensino dos conceitos próprios dessa ciência que, mediados pedagogicamente, possam ser ensinados a propósito de "demonstrar que a ciência é uma das formas de produção da realidade humana, pois por se 
contrapor ao saber natural e espontâneo, ela se desenvolve como forma de conhecimento e de domínio da natureza" (RODRIGUES, 2000: 106).

Pelo conhecimento das leis que regem o natural, o homem cria, a partir do natural, a ordem social e cultural. $\mathrm{E}$ faz isto quando supera o frio, a fome, a chuva, a distância. Cria os instrumentos para controlar, dirigir e superar as forças adversas da própria natureza. Deste modo, o homem pode suplantar a doença, o medo, a fraqueza e seus próprios limites físicos e intelectuais, e estabelecer outros modos de relação entre os homens e a natureza. Assim, altera as suas condições de vida, através do desenvolvimento de processos diferenciados de produção de alimentos, de remédios, de habitação, de proteção. (RODRIGUES, 2000: 107)

A reorganização curricular na escola tem justamente a finalidade de assegurar condições para o ensino com base no conhecimento científico, além do ensino da ética, da estética e das linguagens. A inserção da idéia de direitos da criança a educação tem relação intrínseca com as condições de organização curricular já que é nesse campo que se pode decidir sobre a construção das identidades, da socialização e convívio com a diversidade, pela via da ação educativa.

O conhecimento científico qualifica as práticas sociais. A escola pode aprofundar sua ação educativa imaginando um currículo de Educação Infantil, um currículo de séries iniciais, um currículo de segundo ciclo do $6^{\circ}$ ao $9^{\circ}$ ano e outro currículo para o nível do Ensino Médio, mas introduzindo a questão de sua articulação como questão educativa essencial, de impactos relevantes para a política educacional seja do ponto de vista do financiamento ou das diretrizes de formação. A idéia é que a desfragmentação de espaços vazios entre níveis de ensino supera fatores de desperdício em termos financeiros e de energia criativa no âmbito curricular, com a eliminação de falsas oposições entre esses níveis de ensino. 


\section{A Educação Infantil na Educação Básica}

A inclusão da Educação Infantil no âmbito da Educação Básica é, como já dito, medida do campo das políticas educacionais. Uma das questões polêmicas de todo esse processo diz respeito, justamente, a oportunidade ou não de se considerar a Educação Infantil escola e se deveria ter currículos e programas.

No caso concreto do estudo de campo, Educação Infantil, na cidade de Diadema, é Escola. A decisão de assim denominar as instituições de ensino destinadas a esse nível de ensino teve razões históricas e políticas. Vindo da assistência social, as creches não poderiam continuar sendo consideradas instituições assistencialistas.

Razões dessa ordem política podem contribuir para que essa discussão se aprofunde a ajude a construir a possibilidade de se garantir experiências educativa baseada na ação educativa que respeita, conhece e atua de acordo com as necessidades formativas.

Em vista da experiência de observação em campo, assumo no âmbito desse estudo a idéia de Educação Infantil como Escola reafirmando que essa concepção, no campo da estrutura e funcionamento do sistema municipal de ensino de Diadema, revelou e traduziu as condições em que se pode assegurar direito de acesso a educação.

Acredito que a construção da identidade, a socialização e as diversidades que se articulam e imbricam nos espaços da escola de Educação Infantil, através do processo formativo, são elementos essenciais aos profissionais da educação para orientar o processo reflexivo, próprio do trabalho educacional.

O processo reflexivo, que caracteriza o trabalho docente, depende da decisão que afinal se toma, sobre o que ensinar. Ao professor compete planejar o processo de ensino. As condições de realização do estudo de caso demonstraram a importância de se desenvolver o processo reflexivo na docência, o que conduz a tomada de decisões sobre o que ensinar na Educação Infantil. 
As questões envolvendo o conceito de Lugar, Território e transformação dos espaços geográficos pelas práticas socioespaciais são uma marca na construção das políticas educacionais da cidade de Diadema. Nessas condições é que se justifica propor a introdução do trabalho pedagógico a partir das representações gráficas no Ensino da Educação Infantil.

Ao pensar nas atividades possíveis envolvendo os croquis de localização, entendendo-os como instrumentos de mediação inseridos nas situações de aprendizagem que se articulam para garantir "diferentes referenciais de leitura e relacionamento com o mundo" (RODRIGUES, 2000), aos sujeitos em formação, levanto a hipótese de que estes favorecem a mobilização de interesses das crianças. Por diferentes referenciais de leitura, entenda-se todo o acervo de conhecimentos científicos construídos que acabam por materializar-se na escola em conhecimento escolar bem como todas as possibilidades das instâncias, instituições e processos culturais com os quais a escola interage. A garantia desses acessos, às crianças, é que permitirá a construção das identidades, da socialização e da diversidade como finalidades educativas.

Neste ponto quero pensar que não se pode construir identidades, garantir a sociabilidade, respeitando-se as diversidades, se os sujeitos históricos, e se quisermos pensar em termos de função social da escola, os cidadãos que ali se formam, forem privados das experiências de ensino e aprendizagem tendo como referência a espacialidade que ali se constitui.

Proponho, portanto, que a escola enquanto instância democrática justamente por representar na dimensão do lugar um conjunto de possibilidades educativas, que se ampliam a partir do processo ensino-aprendizagem, crie alternativas de apropriação dos espaços locais, da sua produção e reprodução, consideradas as relações imediatas com a família, com a comunidade e a rigor com a cidade. Mas não se pode restringir a concepção de escola a idéia de que ela fica circunscrita a certas características peculiares.

A escola deve, em qualquer momento do processo pedagógico, ter clareza de seu papel. Há um alvo a 
ser alcançado: a universalização e socialização do saber, das ciências, das letras, das artes, da política e da técnica. Mas há um ponto de partida que não pode ser olvidado: as experiências de vida e a realidade percebida por aqueles a quem ela deve educar. O objetivo deve ser o de elevar o nível de compreensão dessa realidade por parte do educando, que deve ultrapassar a percepção do senso comum em direção a formulações mais elaboradas e organizadas. (RODRIGUES, 2000: 83)

Para pensar essa dimensão e fundamentar o estudo de caso aqui apresentado, penso ser essencial apresentar os Referenciais Curriculares da Educação Infantil como parâmetro para a discussão sobre o que é ensinar na Educação Infantil e porque ensinar a Geografia, como uma das alternativas que podem colaborar para que a escola cumpra as finalidades que acabamos de reafirmar quanto a função social da escola.

\section{O Referencial Curricular Nacional para a Educação Infantil}

O Referencial Curricular Nacional para a Educação Infantil (doravante, RCNEI) é um subsídio destinado a Instituição de Ensino de Educação Infantil quanto a suas práticas, ações de planejamento, organização curricular. Reflete diversas possibilidades teóricas e metodológicas e por sua importância polêmica no contexto educacional, traduz, o pensamento de certa forma, o estado da arte nesse nível de ensino, na última década.

Este RCNEl constituiu-se num conjunto de três volumes destinados a estabelecer referências para a Educação Infantil, pensando arranjos curriculares para essa etapa da Educação Básica. Decorre da apresentação dos Parâmetros Curriculares Nacionais propostos para o ensino Fundamental e Médio. 
A finalidade expressa nos documentos, que justificam sua edição, além de responder a determinação legal, seria a de "contribuir para a definição de metas de qualidade resultado do desenvolvimento integral das crianças, sobretudo de suas identidades" (RCNEI, 1988: 7).

Além de destinar-se ao professor, afirma-se, logo de início no documento, o papel da instituição de ensino como responsável por garantir o acesso e a permanência das crianças pequenas em ambientes propícios a formação.

O RCNEI expressa esse foco formativo e a definição de princípios, objetivos, procedimentos didáticos que deveriam ser implementados nas Escolas de Educação Infantil e nas creches ou instituições semelhantes. Por fim declara compromisso com a dimensão da pesquisa divulgando, demandando e problematizando sua produção e seus resultados.

Considero que esta é uma articulação possível, compatível com os fazeres acadêmicos, mesmo que o documento esteja situado num ponto do debate educacional que tem levado ao profundo questionamento das suas finalidades, princípios e propostas didáticas e metodológicas.

Referencias dessa natureza tornam-se relevantes para a prática docente e para os processos de articulação entre teoria e prática. A polêmica decorrente da discussão acadêmica e a institucional, provocada pelos trabalhadores em educação, a propósito desses parâmetros, fazem parte dos Referenciais propostos e suas indicações acabam por constituir-se em elementos orientadores das construções curriculares de cada instituição, acatando-o ou refutando-o.

Vejamos alguns aspectos relativos a esse debate, indispensáveis ao trabalho educacional e a pesquisa acadêmica. Parece haver um antagonismo entre as correntes de pensamento que consideram os Parâmetros Curriculares Nacionais e, por conseqüência, o RCNEI, elementos de uma política pública que teria caráter prescritivo e restritivo da prática pedagógica e os que enxergam na definição desses Referenciais um instrumento de reflexão para subsidiar a atuação dos profissionais da Educação Infantil. 
Para Oliveira (2002), o RCNEI foi o resultado das ações do Ministério da Educação que identificaram, nas propostas e práticas pedagógicas estudadas em todo o país, uma diversidade de aspectos que apontaram a necessidade de se estabelecer diretrizes para a organização da Educação Infantil:

A partir de um estudo realizado pelo Ministério, em 1994, visando conhecer as propostas pedagógicas, construídas pelos sistemas, tornou-se evidente a necessidade de garantir um paradigma norteador do projeto curricular de educação infantil, sem que isso significasse anular a pluralidade e diversidade existente. (OLIVEIRA, 2002: 38)

Essa é a perspectiva da política pública conforme proposta a partir das instâncias de organização do Estado, no caso o Ministério da Educação (MEC). Embora aponte a busca de referências nas práticas das escolas de Educação Infantil, é considerado documento oficial que traduziria a intervenção do governo nos modos do fazer pedagógico, segundo certo eixo crítico.

Para Bujes (2003), o RCNEl é um discurso pedagógico que recorre a instrumentos e técnicas que teriam "a finalidade de moldar e modelar as condutas infantis". O propósito desses controles visaria o exercício de poder a partir da gestão social, o que teria a finalidade velada de conduzir e direcionar o desenvolvimento dos sujeitos da Educação Infantil. É um risco. Entretanto considero que por serem Referenciais Curriculares, é possível considerar tais documentos tanto na perspectiva de implementação de aspectos que se considere relevantes dentre suas propostas como pode ser a base de formulação de críticas que a escola pode construir, afirmando sua autonomia.

Por outro lado, Arce (2001) considera que a iniciativa de se propor um conjunto de Referenciais para os professores da Educação Infantil minimiza as necessidades de formação docente à altura dos professores desse nível de ensino. 
Por motivos diferenciados dos apresentados por Bujes, também tomo o RCNEI como referência, conforme discutido anteriormente, mas acrescento que particularmente considero os Referenciais discursos pedagógicos sim, mas que por estarem no marco da não obrigatoriedade acabam por organizar elementos de reflexão, como prova o instigante trabalho da própria pesquisadora, o que Ihes dá uma condição diferenciada com relação aos guias curriculares ${ }^{19}$ obrigatórios, de triste lembrança em nosso país.

O RCNEl pode se tornar instrumento de poder para todos os implicados no processo formativo das crianças pequenas. Dependerá da decisão de percurso que cada escola tome quanto a sua proposta educacional, para transformar seu currículo num instrumento, num espaço, num tempo de construção de seu projeto. É assim que penso ser possível imaginar (projetar) possibilidades diversas para a construção de identidades (a essência do currículo) que se busca construir ao longo do e no processo educativo.

Podendo contar com diretrizes comuns ao nível da organização do ensino pode-se garantir também a permanência de uma cultura escolar, que do meu ponto de vista, constitui importante legado do processo civilizatório de um povo ${ }^{20}$. A Escola Pública o é por ter como função social ensinar, garantir acessos mediados, a gerações que chegam, aos acervos culturais, a valores, a princípios formativos construídos historicamente por gerações precedentes.

Uma vez apresentadas as condições e o contexto em que são publicados o RCNEI, a coletânea apresenta o Volume II, cuja abordagem é focada na Formação Social e Pessoal da criança de 0 a 6 anos.

19 Guias curriculares: Documentos de caráter obrigatório, sobretudo com relação a orientação da avaliação, cuja normatização ocorreu através da Lei 5692/71.

20 O povo brasileiro [é] novo porque surge como uma etnia nacional, diferenciada culturalmente de suas matrizes formadoras, fortemente mestiça, dinamizada por uma cultura sincrética e singularizada pela redefinição de traços culturais delas oriundos. Também novo porque se vê a si mesmo e é visto como uma gente nova, um novo gênero humano diferente de quantos existam. Povo novo ainda, porque é um novo modelo de estruturação societária, que inaugura uma forma singular de organização sócio-econômico, fundada num tipo renovado de escravismo e numa servidão continuada ao mercado mundial. Novo, inclusive, pela inverossímil alegria e espantosa vontade de felicidade, num povo tão sacrificado, que alenta e comove a todos os brasileiros. (RIBEIRO, 1996: 19) 
O objetivo prioritário do volume é discutir o processo delicado de se trabalhar com a criança de 0 a 6 anos nas instituições destinadas a esse atendimento. Discutemse os processos de fusão e diferenciação que se estabelece entre a criança e a mãe e a importância da formação de vínculos para a criança pequena.

São discutidas as importantes questões relativas à aprendizagem destacando a imitação, o brincar, a oposição, a linguagem e a apropriação da imagem corporal. O capitulo IV vai retomar aspectos apresentados nesse volume e por esse motivo não vamos aprofundar a discussão que ali se propõe.

Por fim, o Volume III trata do âmbito das experiências da criança com relação as linguagens que utiliza para construir seu conhecimento de mundo. Essas linguagens incluem Movimento, Música, Artes Visuais, Linguagem Oral, e Escrita, Natureza e Sociedade e Matemática. Por ser o volume objeto de nossa investigação na busca das esferas de contribuição da geografia para a discussão curricular da educação infantil ele será discutido no próximo capítulo.

\section{A importância do educar-cuidar em Educação Infantil}

Quando se denomina Educação Infantil o nível encarregado de articular a educação de crianças pequenas atendidas pela creche e pelo que vínhamos chamando de pré-escola aproxima-se duas dimensões que se mantinham organizadas de forma distinta nas instituições destinadas a crianças pequenas: a dicotomia educar-cuidar. Na verdade a criança pequena não pode ser atendida separando-se as duas dimensões. As atividades do cuidar, mediadas pelo adulto, não podem ser desenvolvidas sem que se reconheça nesse fazer os aspectos educativos. Higiene, alimentação, sono, tomar sol, são dimensões que resultam na melhor condição da aprendizagem e da formação.

Essa dupla função, que cabe ao professor, deve merecer atenção muito especial em termos de formação e de planejamento da equipe escolar que vai atuar diretamente com a escola. Essa dimensão deve, portanto, ser compreendida como função pedagógica. 
O atendimento de crianças pequenas, no Brasil, esteve ligado a iniciativas de Estado que buscavam atender populações carentes para as quais o cuidado seria suficiente se consideradas as condições dessas famílias trabalhadoras de baixa renda, o que traduzia uma concepção de infância ${ }^{21}$ referenciada na divisão social de classes.

A urbanização que caracterizou o modelo de desenvolvimento no Brasil é processo que acabou requisitando a entrada da mulher no mercado de trabalho. $A$ necessidade de atendimento das crianças, das camadas populares, cujas famílias sofreram alterações em sua constituição em função dessa nova realidade passou a ser assunto da assistência social e seu atendimento ocorreu em creches, inicialmente filantrópicas, e depois sob a responsabilidade do Estado.

A compreensão de que essa função seja responsabilidade dos professores e da equipe escolar, muda para melhor a possibilidade de se criar um ambiente educativo que amalgama o cuidar como a dimensão que torna esse espaço educativo num ambiente estimulante, iluminado, limpo, desafiador, aconchegante e ao mesmo tempo transforma as atividades de cuidado em eixos do trabalho pedagógico.

Além disto, essa função amplia a compreensão de como se pode criar as condições para a definição dos arranjos curriculares propostos para a escola de Educação Infantil.

O acesso a conhecimentos variados também se relaciona com as atividades envolvidas no educar-cuidar. O Volume três do RCNEI é tomado justamente como referência para considerar aspectos formativos da criança pequena ${ }^{22}$, a partir da hipótese de que os conhecimentos geográficos contribuem para a construção do raciocínio geográfico.

${ }^{21}$ Infância: entendida não como um acontecimento estático, mergulhado em um vazio social, mas sim como um fenômeno contextualizado e, por isso, tratado em relação a temas sociais, políticos e econômicos do mundo contemporâneo, como a democracia e as mudanças no capitalismo (DAHLBERG et al., 2003).

22 Criança: entendida como um sujeito histórico, co-construtora de conhecimento e de identidade, em sua interação com os adultos e com as demais crianças. (DAHLBERG et al., 2003).

Criança pequena: conforme conceituado anteriormente. 
A construção da identidade da criança passa, portanto, por iniciativas da escola em construir um projeto pedagógico capaz de organizar um currículo que responda a essas necessidades formativas.

As crianças apreciam a exploração e a investigação do meio que as cerca. A natureza e a sociedade são realidades que as crianças têm o direito de conhecer a partir da perspectiva cultural e social construídas nesse contexto em que vivem. É o aprofundamento deste aspecto que fazemos no próximo capítulo. 


\section{CAPÍTULO II - NATUREZA E SOCIEDADE}

\section{Natureza e sociedade}

As questões que envolvem o ensino de Geografia constituem objeto de interesse de pesquisa e investigação de diversos segmentos. Para a Universidade, responsável pela formação docente na licenciatura, esta é uma questão mais que interessante. Trata-se de buscar alternativas para que a demanda social pelo conhecimento científico seja atendida pela disponibilização de um campo de saberes escolares (pertencente ao âmbito das práticas sociais globais) organizado através da construção de propostas curriculares que tomem, do conhecimento científico, referências para sua constituição, dentre outras possibilidades filosóficas, estéticas e culturais.

Entendo que há uma relação entre a Ciência e as disciplinas escolares. Conforme Cavalcanti,

[...] a ciência geográfica constitui-se de teorias,
conceitos e métodos referentes à problemática de
seu objeto de investigação. A matéria de ensino
Geografia corresponde ao conjunto de saberes
dessa ciência, e de outras que não tem lugar no
ensino fundamental e médio como Astronomia,
Economia, Geologia, convertidos em conteúdos
escolares a partir de uma seleção e organização
daqueles conhecimentos e procedimentos tidos
como necessários à educação geral. (1998: 9)

No Brasil, o ensino da Geografia no Ensino Médio e Fundamental, a partir das questões propostas pela Geografia Crítica, em meados dos anos 70, contribuiu para que os professores refletissem sobre uma prática educativa e pedagógica que poderíamos dizer, vendo retrospectivamente, buscou reformular e problematizar o ensino baseado na Geografia Tradicional. 
A busca de novos fundamentos para o ensino da Geografia, a partir daí, resultou na emergência de um debate que trouxe as questões envolvidas no compromisso docente para o ensino da Geografia, instigadas por Lacoste, dentre outros, avançando no sentido de se tomar o espaço geográfico e as referências dos alunos - o que envolve seus saberes prévios e a realidade em que vivem - para organizar o ensino, tomar decisões quanto a metodologia e diretrizes didático-pedagógicas.

Para Cavalcanti,

no balanço geral do movimento de renovação da Geografia nas últimas décadas, duas questões precisam ser destacadas: [...] Os modestos efeitos na prática de ensino dos professores de Geografia, comparados com questionamentos, análises e propostas "renovadas" feitos em nível teórico, e a reflexão dessa prática a partir de uma referência pedagógico-didática, também incipiente (1996: 20).

Se o balanço geral do movimento de renovação da Geografia não impactou as transformações no âmbito do ensino, considerando-se o ensino fundamental ( $5^{\mathrm{a}}$ a $8^{\mathrm{a}}$ séries) e Ensino Médio, mais dramática tem sido a questão do ensino nas séries iniciais.

A Geografia Escolar tradicional acabou sendo referência na formação da grande maioria dos professores das séries iniciais do Ensino Fundamental. Na Educação Infantil, esta discussão ainda não foi feita suficientemente. Como é central no âmbito deste estudo, vamos aprofundá-la adiante.

Uma questão relevante para se pensar o ensino da Geografia diz respeito a abordagem didática e pedagógica do ensino das Ciências Humanas nas séries iniciais o que inclui o ensino da ciência geográfica. Para essa etapa inicial do ensino fundamental o debate proposto por Vesentini (1995; apud CAVALCANTI, 1996: 23) de que o ensino da Geografia se deve "ao interesse 
renovado em virtude do processo de globalização" - é pertinente. Vesentini afirma que, a propósito desse debate,

a natureza e os problemas ecológicos tornaram-se mundiais ou globais, adquiriram um novo significado quando se organiza o ensino para que o aluno possa descobrir o mundo em que vivemos, com especial atenção para as escalas locais e nacional, enfocando criticamente a questão ambiental e as relações sociedade/natureza, através de estudos do meio, interpretando textos, fotos, mapas, paisagens (VESENTINI, 1995; apud CAVALCANTI, 1996: 23).

Nas séries iniciais estas questões chegaram a sala de aula pela via dos temas transversais. Muito das especificidades do ensino da Geografia passou a ser planejado no âmbito dos projetos desses temas, tendo ocorrido uma confusão entre metodologias e procedimentos didáticos e o ensino dos saberes geográficos. Adiante proponho uma reflexão sobre o lugar da Geografia na organização das matrizes curriculares, através de sua materialização em grade horária.

Além da equivocada abordagem de temas da Geografia outra dificuldade se verifica quanto aos objetivos de ensino, nas séries iniciais, para as quais acredito vale a proposta de Pereira (apud CAVALCANTI, 1996: 23) expresso nas seguintes condições: "creio que é possível afirmar que a missão, quase sagrada, da geografia no ensino é a de alfabetizar o aluno na leitura do espaço geográfico, em suas diversas escalas e configurações".

As dificuldades apontadas acima tornam complexo o processo de ensino da Geografia Escolar nas séries iniciais, na medida em que outra dificuldade de natureza política agrava esse quadro: os professores não são formados para trabalhar com objetivos que envolvam estas novas possibilidades conceituais.

A Geografia das séries iniciais é influenciada pela abordagem de temas que Visentini caracterizou através do exemplo "A Terra e o Homem". Em geral os 
professores traçam seus objetivos em função dos conteúdos a transmitir. Para Santos (apud CAVALCANTI, 1996: 23) essa concepção formal precisa ser enfrentada a partir da ruptura epistemológica, e os professores comprometidos, instigados a trabalhar "numa perspectiva dialética, em movimento e por contradição", que resultaria numa possibilidade de ensino que cria as condições objetivas para o questionamento, para a indagação, para a vivência da contradição que desafia aos processos de sua superação.

Cavalcanti (1996: 24) afirma as finalidades do ensino da Geografia para crianças e jovens, quanto à "oportunidade destes aprenderem a formar raciocínios e concepções mais articulados e aprofundados a respeito do espaço".

Trata-se de possibilitar aos alunos a prática de pensar os fatos e acontecimentos enquanto constituídos de múltiplos determinantes; de pensar os fatos e acontecimentos mediante várias explicações, dependendo da conjunção desses determinantes, entre os quais se encontra o espacial (CAVALCANTI, 1996: 23).

Fundamental para se organizar o ensino, a partir das concepções de Cavalcanti (1996) é considerar a mediação ${ }^{23}$ como conceito central para o ensino dos conhecimentos relativos ao espaço, articulados, construídos historicamente, suficientes para explicar as práticas socioespaciais ${ }^{24}$ enquanto realização humana diversa e complexa.

conceito de mediação e sua centralidade para o ensino da Geografia podem fundamentar as ações de enfrentamento da tradicional geografia dos professores $^{25}$, que acabam reproduzindo metodologias e procedimentos

${ }^{23}$ O conceito de mediação é objeto de discussão no próximo capítulo. Em síntese refere-se a atuação de par mais experiente capaz de favorecer o acesso do sujeito que aprende aos objetos de conhecimento.

24 A prática socioespacial se revela no espaço quando este aparece como condição, meio e produto da reprodução social (FANI, 2001: 12).

25 Geografia dos professores: consiste num discurso ideológico no qual uma das funções inconscientes é a de mascarar a importância dos raciocínios centrados no espaço (LACOSTE, 2006, 14). 
didáticos destinados a memorização do fato geográfico decorrente dos trabalhos descritivos de uma Geografia tradicional de compêndios. Processos descritivos como método e prática pedagógicos impedem a emergência das situações de aprendizagem organizadas através de atividades destinadas ao desenvolvimento do raciocínio geográfico, que recorrem a observação, análise, levantamento de hipótese, problematização, sínteses.

Lacoste propõe a categoria conceito-obstáculo ${ }^{26}$, para argumentar que certas características da geografia dos professores trabalham noções que não incluem as práticas sociais e espaciais, pensando a formação das crianças e jovens, de tal forma que se tornam conhecimentos circunscritos a esfera escolar e, acrescento, propostos como ticket de acesso a uma etapa posterior de escolaridade.

O ensino da geografia escolar parece abstrair certas categorias que poderiam inserir o aluno numa perspectiva de formação que incorporasse os ganhos de um projeto unitário superando as dicotomias entre Geografia Humana e Geografia Física, essencial ao desenvolvimento do raciocínio geográfico.

No Brasil, a partir dos anos 80 , quando as obras de Lacoste e Santos ${ }^{27}$ impactam o debate que leva a renovação da Geografia vamos observar que a formação dos professores do Ensino Médio e Fundamental ( $5^{\mathrm{a}}$ a $8^{\mathrm{a}}$ séries) é beneficiada em função do debate acadêmico que alcança as Licenciaturas, o que representa a possibilidade de acesso ao vigoroso debate travado nesse campo teórico.

A partir da Universidade, observa-se uma retomada de aspectos essenciais ao ensino através de novas propostas pedagógicas, como foi o caso da edição, em 1987, das propostas curriculares para o ensino da Geografia destinadas ao ensino da $5^{\mathrm{a}}$ a $8^{\mathrm{a}}$ série e ao curso Colegial no Estado de São Paulo.

27 Prof. Dr. Milton Santos, graduado em Direito, desenvolveu trabalhos em diversas áreas da Geografia, em especial nos estudos de urbanização do Terceiro Mundo. Foi um dos grandes nomes da renovação na geografia brasileira ocorrida nos anos 70 . Durante toda a vida buscou métodos e visões diferentes para encarar seus temas de estudo. Lecionou em diversas universidades mundo afora. Regressou ao Brasil em 1977, tendo trabalhado na Universidade Federal Fluminense ingressando na Universidade de São Paulo em 1984. 
O mesmo não ocorreu com as séries iniciais. A formação dos professores de $1^{\mathrm{a}}$ a $4^{a}$ série, segundo a organização do ensino da época, deu-se majoritariamente, até 1996, através da habilitação para o Magistério em nível médio, numa dimensão polivalente, com ênfase maior nos procedimentos didáticos compreendidos como conjunto de técnicas destinadas a organização planejada da aula e menos como articulação entre metodologia, finalidades sócio-políticas e pedagógicas da educação formal e suas bases teóricocientíficas e, aí sim, o conjunto de técnicas de planejamento, organização e condução mediada do processo ensino-aprendizagem.

Há uma geração de professores que só recentemente passa a formar-se em nível superior, a partir das novas diretrizes legais, tendo finalmente acesso as metodologias de ensino das diversas disciplinas que constituem as matrizes curriculares da Educação Infantil e das séries iniciais do Ensino Fundamental, habilitação principal dos Cursos de Pedagogia.

É muito recente, considerado o tempo histórico, que os professores das etapas iniciais da Educação Básica, passassem a buscar através dessas metodologias os princípios, os conceitos e as melhores condições para o ensino das diversas disciplinas escolares, organizadas a partir da ciência formal.

Ainda assim as metodologias de ensino que alcançam a formação dos professores através da Pedagogia não podem, porque a própria Geografia não o fez, resolver as questões epistemológicas que sustentariam as condições para o ensino do espaço geográfico como a oportunidade de pensar os fatos e acontecimentos enquanto constituídos de múltiplos determinantes, entre os quais se encontra o espacial, conforme referido acima, desde as etapas iniciais da Educação Básica.

\section{O Conhecimento Geográfico em busca de espaço, na Instituição Escolar}

O livro A Geografia, isso serve em primeiro lugar, para fazer a guerra, de Lacoste, poderia ser dessas obras fundamentais que ficam datadas e circunscritas a seu tempo histórico, a sua conjuntura de elaboração e a seu 
contexto cultural. Não é isso que ocorre quando retomamos aspectos centrais desse livro, que marcou a emergência dos movimentos que resultaram nas formulações da Geografia Crítica.

E é por esse motivo que volta a ser referência nestas reflexões que procuram distinguir o papel da Geografia praticada pelos professores, aquela praticada academicamente e a Geografia fundamental/formal, que tem permitido, conforme demonstra a História, o apossamento dos espaços e seus territórios pelos que exercem o poder, conforme a tese que sustenta Lacoste.

À Geografia Escolar cabe organizar e identificar o conjunto de conceitos que, penso, sejam considerados essenciais ao ensino, consideradas as diversas possibilidades teóricas - lugar, paisagem, região, território, natureza e sociedade.

Equívocos na construção conceitual comprometem o ensino da Geografia, obstaculizando a construção do raciocínio geográfico. Ocorre a fragmentação de categorias que deveriam ser abordadas a partir da consideração de uma referência conceitual dominada pelo docente das séries iniciais do Ensino Fundamental e da Educação Infantil. A Geografia Escolar clássica abstrai do lugar e de suas paisagens, da região, do território, da natureza e sociedade as categorias de análise, para transformá-las em conceitos centrais, que Lacoste chamou de conceito-obstáculo ${ }^{28}$ quando utilizados para realizar uma análise que aproxima, por exemplo, as regiões a partir da referência conceitual ignorando-se as peculiaridades exigidas para saber pensar o espaço (2006: 53).

Mais instigante é considerar como o raciocínio geográfico pode ser desenvolvido, desde a Educação Infantil, quando se pensa a Educação Básica. As práticas pedagógicas do Ensino Fundamental e da Educação Infantil distinguem-se (estas não podem antecipar aquelas), mas a abordagem das questões metodológicas para o ensino dos conceitos geográficos são objeto de

${ }^{28}$ Conceito-Obstáculo: (proposto por Lacoste e, aqui, sintetizado por Bartel) a regiãopersonagem que impõe uma divisão do conhecimento geográfico em verdadeiras "gavetas" desconectadas de coerência, mas que ao mesmo tempo persiste em contribuir na dualidade entre natureza e sociedade. Bartel lembra que Lacoste tomou de Gaston Bachelard a noção de conceito-obstáculo para criticar o conceito de região (na tradição francesa), na medida em que seu apelo à síntese do conhecimento despolitiza o discurso geográfico. 
interesse de todos os níveis de ensino da Educação Básica. Discussão desta natureza precede, na escola e nas instâncias que organizam o sistema de ensino, outras decisões sobre as especificidades de cada nível de ensino, buscando não hierarquizá-los.

Proponho refletir sobre o que tem sido o ensino da Geografia nas séries iniciais para investigar algumas condições prévias para o ensino na Educação Infantil, através do eixo Natureza e Sociedade, buscando a construção de uma possibilidade de arranjos curriculares coerentes com cada um desses níveis e coerentes com as práticas pedagógicas significativas a cada um deles.

\section{A Geografia Escolar nas Séries Iniciais - uma reflexão}

Nas séries iniciais, ainda se pratica uma Geografia de manuais, em que a lição de Geografia está associada à de História. Examinando os cadernos de dois sistemas de ensino que trabalham em convênio com um grande número de escolas particulares de médio porte, no Estado de São Paulo, vamos verificar, na $4^{\mathrm{a}}$ série, uma integração de conteúdos (não a interdisciplinaridade ${ }^{29}$ ) em que ao relato histórico segue-se a indicação no mapa, da localização de alguns desses eventos históricos.

Prevalecem conceitos que associam, por exemplo, o engenho, do século XVIII, como um novo elemento da paisagem em função da colonização através das capitanias. A organização das capitanias hereditárias não é problematizada e os donos de engenho são apresentados como grandes proprietários.

29 Interdisciplinaridade: há uma complexa discussão sobre as possibilidades conceituais. Vejamos um fragmento deste debate: "[...] como a arte do aprofundamento com sentido de abrangência, para dar conta, ao mesmo tempo, da particularidade e da complexidade do real" (DEMO: 89).

"[...] é na convivência com especialistas de outras áreas que o cientista submete suas teorias, impregnadas de particularismos de sua área específica, ao crivo da crítica de seus, por assim dizer, primos. Portanto, a característica principal da interdisciplinaridade é o conflito e não a harmonia" (SIEPIERSKI, 1998: 27).

Veiga-Neto (1996) entende a interdisciplinaridade como um trabalho conjunto de várias disciplinas em direção do mesmo objeto de pesquisa, com o propósito de aproximá-lo, cada vez mais, da realidade objetiva, à medida que constrói sua perspectiva dialética.

É importante acrescentar que o debate sobre Interdisciplinaridade se desdobra em duas perspectivas: epistemológica e pedagógica. Formuladas, respectivamente, por Japiassú (1982) e Fazenda (1996). 
Um exemplo como este, que agrupa em poucas linhas um conjunto de problemas conceituais (definição de paisagem sem questionamento desse novo elemento, colonização através de capitanias como dado histórico efetivo, promoção de figura histórica a condição de vitorioso) torna oportuno retomar alguns pontos propostos por Lacoste. Ao professor da Educação Básica, ensinando nas séries iniciais, não cabe, a menos que seja uma opção de caráter pessoal e profissional, assumir aspectos do debate acadêmico acerca das perspectivas da Geografia e as alterações epistemológicas provocadas pelo debate desse campo. Lacoste, quanto a isso, faz importante distinção entre o objeto da ciência e o campo do conhecimento geográfico afirmando:

$$
\begin{aligned}
& \text { Pouco importa em última análise - se a geografia é } \\
& \text { ciência - a questão não é essencial, desde que se } \\
& \text { tome consciência de que a articulação dos } \\
& \text { conhecimentos relativos ao espaço, que é a geografia, } \\
& \text { é um saber estratégico, um poder (2006: 23). }
\end{aligned}
$$

Entrevistando crianças usuárias das apostilas ${ }^{30}$ referidas, apuramos que elas entendem a geografia como o estudo da superfície terrestre e das regiões (estas concebidas como espaços administrativos). Eis aí o conceito-obstáculo para o ensino efetivo da Geografia.

Não é objeto deste estudo tomar a direção da análise que procura distinguir uma Geografia Escolar, a Geografia Acadêmica-universitária e Geografia como Ciência. Mas é importante apontar os nódulos que se formam, quando a construção de referências epistemológicas (recorrendo aqui a reflexão desse aspecto por Lacoste) cria obstáculos que comprometem a formação de gerações que se sucedem e as finalidades efetivas desses processos formativos que garantem a constituição da cidadania.

As crianças têm direito de acesso a explicações científicas para o resultado de suas experiências no âmbito dos espaços em que vivem, atuam, observam,

${ }^{30}$ Os sistemas de ensino trabalham com apostilas que são organizadas formalmente a partir dos Parâmetros Curriculares, mas que a rigor seguem uma lógica própria, o que lhes dá a identidade. A princípio isto não é objeto de crítica. 
constroem conhecimentos, entram em contato com as práticas socioespaciais e globais produzindo-as e reproduzindo-as. Quem deve responder a essas necessidades formativas é o professor e a equipe escolar. E só podem fazê-lo a partir da chamada Geografia Escolar.

\section{Uma Geografia dos professores}

A problematização da geografia dos professores pode remeter a reflexão da prática pedagógica, própria da ação docente, tomando-se a questão da exclusão do raciocínio geográfico como problema central, para repensar uma prática que reforça e mantém intocadas a abstração das razões estratégicas que envolvem o saber geográfico utilizado nos círculos de poder, como proposto por Lacoste ${ }^{31}$.

O ensino das séries iniciais traz uma prática docente que se estabelece como discurso pedagógico de tipo enciclopédico. As preocupações curriculares recaem sobre o ensino dos elementos geográficos - clima, relevo, vegetação, população... - de forma desarticulada, enquanto nomenclatura, descontextualizado, que recorre mais a memória que a compreensão dos elementos constituintes do raciocínio geográfico.

As crianças tendem a considerar a Geografia uma disciplina escolar menos importante e enfadonha (o próprio Lacoste a caracteriza assim quando a considera no contexto escolar).

A perspectiva crítica dos estudantes sobre a presença da Geografia no currículo escolar se repete em outras disciplinas. Todavia, reconheço que outros indicadores remetem ao exame da situação que cerca a Geografia Escolar considerando o "seu lugar" na grade curricular ${ }^{32}$, pela análise da carga

31 Yves Lacoste $(2006,14)$ propõe a seguinte reflexão acerca do real sentido de ocultação da importância do conhecimento geográfico em função de "[...] razões estratégicas para a dissimulação dos sentidos, aos olhos da maioria,da eficácia dos instrumentos de poder que são as análises espaciais".

32 Grade curricular: é o elemento que representa e materializa o tipo de organização curricular que efetivamente se pratica na escola. Em que pese a busca por uma prática pedagógica coerente com uma concepção de currículo que valorize todas as áreas do conhecimento, conforme a legislação atual, a grade revela o lugar efetivo de cada disciplina nessa organização. 
horária a ela destinada, nas séries iniciais. O anexo 1 da Resolução SE 11 da Secretaria de Educação do Estado de São Paulo (ver Tabela 1), é um bom exemplo da organização da carga horária correspondente a matriz curricular em escolas estaduais, nas séries iniciais.

Tabela 1: Anexo 1 da Resolução SE 11, de 11-2-2005, que estabelece diretrizes para a organização curricular do Ensino Fundamental nas escolas estaduais.

\begin{tabular}{|c|c|c|c|c|c|}
\hline & $\begin{array}{l}\text { ATRIZ CURRICULAR BÁSICA PAR/ } \\
\qquad \text { CICLO I- } 1^{\mathrm{a}} \text { a } 4^{\mathrm{a}}\end{array}$ & $\begin{array}{l}\text { ENSI } \\
\text { ERIES }\end{array}$ & FUND/ & ENTAL & \\
\hline \multirow{8}{*}{$\begin{array}{l}\text { Base } \\
\text { Nacional } \\
\text { Comum }\end{array}$} & \multirow{2}{*}{ Disciplinas } & \multicolumn{4}{|c|}{ Séries/aulas (\%) } \\
\hline & & $1^{a}$ & $2^{a}$ & $3^{a}$ & $4^{a}$ \\
\hline & Língua Portuguesa & $35 \%$ & $35 \%$ & $30 \%$ & $30 \%$ \\
\hline & História/Geografia & $10 \%$ & $10 \%$ & $10 \%$ & $10 \%$ \\
\hline & Matemática & $30 \%$ & $30 \%$ & $35 \%$ & $35 \%$ \\
\hline & Ciências Físicas e Biológicas & $10 \%$ & $10 \%$ & $10 \%$ & $10 \%$ \\
\hline & Educação Física/ Educação Artística & $15 \%$ & $15 \%$ & $15 \%$ & $15 \%$ \\
\hline & Total Geral & $100 \%$ & $100 \%$ & $100 \%$ & $100 \%$ \\
\hline
\end{tabular}

Este anexo indica como devem ser distribuídas as disciplinas nas séries iniciais do Ensino Fundamental. Ali há uma indicação em \% sobre como se deve distribuir a carga horária de cada uma delas. A recomendação está baseada na legislação que trata da definição de uma base nacional comum quanto à organização curricular.

Há dois aspectos relevantes neste anexo. Não se oferece a escola os argumentos pedagógicos que justificariam a adoção dessas porcentagens que não resistem a um confronto com as normas legais da LDB de 1996. Se confrontada com a concepção de educação que perpassa a legislação fere o princípio da interdisciplinaridade, por um lado, e da autonomia pedagógica pretendida pela legislação como atributo da atividade educativa formal, que se realiza através da escola, por outro.

A escola deveria ter as condições para decidir sobre a organização interna de sua matriz curricular. Qualquer explicitação de modelo organizativo acaba se transformando em norma. Sobretudo porque o próprio processo de supervisão 
do ensino encontraria imensa dificuldade para lidar com a autonomia pedagógica da escola. Mas esta já é uma outra questão.

Esta super fragmentação da matriz curricular efetiva a idéia - em pleno século XXI - de que há uma "ordem" hierárquica ao se considerar o conhecimento ao qual as gerações devem ter acesso por direito. Seu fundamento é supostamente científico, tendo por base a demonstração matemática de que 10\% de História e Geografia são suficientes para a formação do aluno, que divididos entre si chegariam a $5 \%$ da carga horária para cada uma. Isto interfere na lógica da distribuição de conteúdos de formação, destinados a crianças de 6 a 10 anos (já contando com a realidade do ensino fundamental de nove anos). E interfere na organização do processo didático e metodológico.

A partir de minha experiência como professora de escola de Ensino Fundamental nas séries iniciais e observando tal organização constato que as áreas do conhecimento destinadas a formação de conceitos científicos ficam subordinadas as áreas de Língua Portuguesa e Matemática, estando as demais sujeitas as prioridades dessas disciplinas.

No caso das séries iniciais há uma causa que reforça essa subordinação e diz respeito, justamente, há uma particularidade das matrizes curriculares que vigoraram, por força de lei, até 1996 quando a nova LDB entrou em vigor. Até esse momento as disciplinas História e Geografia constituíam uma "disciplina" escolar que apresentava os conteúdos de ambas, denominada Estudos Sociais.

Nas séries iniciais, Estudos Sociais foram tratados como um conjunto de conteúdos, recortados de História e Geografia, que dariam certa base enciclopédica a aspectos julgados necessários ao desempenho dos estudantes ao longo da vida escolar.

Por outro lado, a questão da formação docente também impactou o ensino de Geografia. Muito das escolhas curriculares, sobre o que ensinar em Estudos Sociais, recaía sobre as dificuldades da formação polivalente das professoras 
de séries iniciais que não traziam qualquer aprofundamento nessas áreas do conhecimento, como já discutimos.

Assim a tendência era trabalhar com os aspectos predominantes encontrados nos livros didáticos. Estes por sua vez acabavam por reproduzir os aspectos considerados essenciais à iniciação do aluno em áreas do conhecimento que viriam a ser aprofundadas a partir do que hoje chamamos de segundo ciclo do ensino fundamental.

Este exemplo confirma a questão levantada por Lacoste na década de 80. O lugar da Geografia na formação das crianças é secundário, ministrado de forma pouco significativa, pouco focado no trabalho de construção de conhecimentos destinados as possibilidades de uso do raciocínio geográfico.

[...] impôs-se a idéia de que o que vem da geografia não deriva de um raciocínio, sobretudo nenhum raciocínio estratégico conduzido em função de um jogo político. A paisagem! Isso se contempla, isso se admira; a lição de geografia! Isso se aprende, mas não há nada para entender. Uma carta! Isso serve para quê? É uma imagem para agência de turismo ou o traçado do itinerário das próximas férias (2006: 34).

Aqui cabe ressaltar que, mesmo agora, quando vivemos na escola o apelo legal a implementação de Parâmetros Curriculares que apontam para a necessidade de se contextualizar o ensino e desenvolver o trabalho interdisciplinar, à Geografia, para ficarmos no caso das séries iniciais, cabe ensinar sobre o espaço aquilo que dê as crianças certa autonomia de uso de itinerários e localização em função de uma perspectiva utilitária.

Isto nos desafia a imaginar um outro lugar para a consideração do ensino da Geografia. As práticas sociais que são também práticas espaciais estão presentes na vida da criança desde seu nascimento. 
As práticas sociais resultam das representações do espaço. É necessário reconhecer que, de fato, as pessoas dependem de certa representação dos espaços onde trabalham, moram, consomem. Mas há também a representação dos espaços daqueles que organizam a administração, o consumo, a produção.

As redes que se estabelecem a partir daí definem papeis diversos para os que são produtores e os que consomem, os que administram e os que são administrados, os que planejam os fluxos de escoamento das mercadorias e os que conduzem os meios de transporte destinados a distribuição.

Lacoste (2006) nos adverte que aos que produzem, aos que administram, aos que planejam - e hoje temos uma área super especializada encarregada da logística de transporte - é possível o acesso aos estudos que revelam a melhor estratégia de, em determinada extensão e configuração de espaço, articular as finalidades de sua ação.

Aos trabalhadores e consumidores, entretanto, o mesmo conhecimento é pouco acessível, pois estes dominam e se relacionam com aspectos parciais das redes que constituem sobre os territórios pelos quais circulam.

Por vezes ignoram a multiplicidade de redes superpostas com as quais se relacionam. Lacoste propõe que se considere a complexidade que caracteriza o espaço e sua representação a partir do reconhecimento de que há uma espacialidade diferencial que permite compreender, a partir de escalas geográficas diversas, tal complexidade da organização do espaço. Defende ainda que representá-lo adequadamente e permitir que a interpretação dessas representações esteja baseadas no raciocínio geográfico é que torna possível a todo cidadão apropriar-se de seu território e reconhecer os papeis que exerce em função dos espaços que produz e reproduz através das relações e práticas sociais globais.

Essencialmente ensinar e aprender sobre o espaço geográfico, depende de adequada capacidade de raciocínio geográfico. Assim é pertinente a discussão trazida por Simielli, na década de 80 , que problematizava acerca da 
necessidade de se desenvolver na escola a alfabetização cartográfica, o que será foco de discussão no Capítulo IV.

Ao retomar e questionar a Geografia dos Professores, propus como pertinente retomar de Lacoste, os conceitos espacialidade diferencial e conceitoobstáculo. Essa discussão remete ao que Lacoste chama de certa comodidade pedagógica no ensino da Geografia, o que neste trabalho atribuo às dificuldades e peculiaridades da formação docente, no Brasil.

A proposta de Lacoste de se pensar um projeto unitário para a Geografia, constituiria um importante passo epistemológico de grande impacto para a Geografia Escolar e para a prática pedagógica.

Defendo que é tarefa da Geografia Escolar tomar decisões, no âmbito da organização curricular, sobre o ensino na Educação Básica. A Educação Básica tem por finalidade, determinada legalmente, formar a infância e juventude a partir de valores e princípios claros e objetivados. A aprendizagem é, portanto, questão central para os alunos que passam a estar no sistema desde 0 anos de idade.

A concepção de aprendizagem que trago fundamenta-se nas Leis de natureza cientifica que demonstram a possibilidade de o ser humano aprender, através da mediação de parceiro mais desenvolvido, desde as mais tenras experiências com seu meio social e cultural.

Não se pode adiar a tarefa de se garantir às crianças acesso ao mundo do conhecimento, a partir daqueles bens culturais que formam para a plenitude das práticas sociais. Do ponto de vista da Educação Infantil, o tema/eixo Natureza/Sociedade trazido através do RCNEI é essencial para se pensar o processo ensino -aprendizagem desde essa etapa inicial da Educação Básica, como vimos no Capítulo I. 


\section{Representações Gráficas e Croquis: Uma aproximação com o eixo Conhecimento de Mundo - Natureza e Sociedade na Educação Infantil}

Para compreender o eixo Natureza e Sociedade, presente nos eixos de trabalho dos arranjos curriculares da Educação Infantil vou apresentar aspectos relevantes do documento que subsidiam minha reflexão sobre as questões envolvendo as situações ensino-aprendizagem e inserção, aí, de atividades baseadas na interpretação das representações gráficas (croquis de localização).

\section{O Referencial Curricular Nacional para a Educação Infantil - Volume III}

Na Educação Infantil, os eixos temáticos envolvendo Natureza e Sociedade estão organizados através do Volume III - Conhecimento do Mundo que propõe as questões relativas a formação da criança incluindo as contribuições das ciências, da cultura, da arte, no âmbito das práticas sociais globais e sócio espaciais.

O documento, enquanto materialização de uma política pública, traz, conforme já debatemos, a expressão de um consenso possível na sua elaboração. $O$ volume aborda questões do ensino e aprendizagem relativos à Movimento, Música, Artes Visuais, Linguagem Oral e Escrita, Natureza e Sociedade e Matemática. A concepção metodológica que perpassa o material se refere ao campo das teorias sócio históricas.

As contribuições da Geografia Escolar, que proponho a princípio como elemento de reflexão no campo da prática pedagógica, pode ser pensada a partir do eixo Natureza e Sociedade como articulador dos conhecimentos geográficos, ao grande tema Conhecimento do Mundo que nomeia o Volume III.

Na Educação Infantil vem sendo possível superar a idéia de disciplina e especialização ao se propor arranjos curriculares por eixos temáticos. Nesse sentido os Referenciais avançam da idéia disciplinar para as possibilidades que os eixos temáticos garantem, ao se trabalhar com crianças pequenas, de se abordar as questões, temas, eixos de interesse que vão sendo trazidos pelas 
próprias crianças ou propostas pelos professores e educadores, de acordo com as necessidades formativas.

Destaco os elementos essenciais que constituiriam os eixos do trabalho pedagógico que se sugere organizar a partir do RCNEI. O documento está organizado para abordar fundamentos, aspectos didáticos, metodológicos para a atuação dos educadores, com crianças desde zero anos de idade.

Neste trabalho a introdução das representações gráficas ${ }^{33}$ como instrumentos de mediação, apropriado a prática pedagógica e a organização de atividades com crianças entre 3 e 6 anos, supõe o detalhamento das propostas de trabalho para a faixa etária de 4 a 6 anos. Trata-se, apenas, de procedimento metodológico que respeita a organização interna do documento.

Esclareço que a inclusão da criança de 3 anos ocorre, justamente, por que reconheço que os fatores envolvidos na dinâmica de organização da escola, da vida na família e na comunidade podem aproximar as crianças em suas experiências formativas, dependendo a aprendizagem e o desenvolvimento muito mais da mediação que se garante a essas crianças nas relações adulto/criança e criança/criança e criança/ coletivos diversos, do que na consideração rígida da atividade de ensino organizada por padrões etários.

\section{A organização do Volume III do RCNEI - Conhecimento de mundo}

O volume aborda os temas Movimento, Música, Artes Visuais, Linguagem Oral e Escrita, Natureza e Sociedade, Matemática. Para cada um desses eixos temáticos são apresentadas considerações gerais justificativas, e o foco de interesse destes na organização da matriz curricular da Educação Infantil.

Em seguida são apresentados objetivos para a abordagem de cada tema distinguindo as faixas etárias de 0 a 3 e 4 a 6 anos. Os objetivos acabam por

33 Representações gráficas: inclui-se no universo da comunicação visual, que por sua vez faz parte da comunicação social. Participa, portanto, do sistema de sinais que o homem construiu para se comunicar com os outros. Compõe uma linguagem gráfica bidimensional, atemporal, destinada à vista (DIAS, 2000: 13). 
indicar as capacidades que as crianças deverão desenvolver ao final do ciclo que organiza os grupos referidos.

Em seguida são sugeridas possibilidades de organização dos conteúdos, considerados relevantes para cada um dos eixos apontados. A esses se seguem as orientações gerais para o professor e os aspectos relativos a observação, registro e avaliação do processo educativo.

Antes de apresentar a síntese desse volume e tema que nos interessa problematizar, até por questões metodológicas, quero apresentar uma discussão muito breve dos conceitos Natureza e Sociedade, pois acredito que isto esclarece algumas das escolhas que venho fazendo ao longo do trabalho quanto à construção de meus argumentos para prever as representações gráficas como conteúdos e elementos do campo didático metodológico, relevantes na Educação Infantil.

O propósito é situar teoricamente esses conceitos que podem ser definidos de forma ampla, a partir de perspectivas diversas das Ciências que a eles recorrem.

No campo da Geografia o debate conceitual em torno de Natureza tem gerado antagonismos que não pretendo discutir aqui. O que desejo registrar é uma nota sobre as definições que mais comumente foram tomadas como referência nesse campo geográfico.

A noção de Natureza como organismo inteligente permitia comparar o mundo natural e o mundo do ser humano, na tradição grega. No Renascimento a Natureza é concebida, não como organismo, mas como articulação de partes conjugadas, cujo fim é determinado por um espírito inteligente e exterior a ela, estando presente nessa concepção a idéia do divino, do senhor da natureza, que se transformaria numa idéia de senso comum ainda presente na contemporaneidade. Numa visão moderna de Natureza, surgem as concepções evolucionistas, marcadas pela noção de processo e transformação. 
Dessa visão moderna decorrem duas concepções que resultarão na emergência de uma visão organicista (base biológica) referente às idéias positivistas e a uma visão dialético-materialista referente as idéias marxistas.

Particularmente tomo a concepção marxista como relevante para a compreensão da dialética da Natureza que, segundo esse ponto de vista científico, surge do processo de troca material que o homem estabelece com a natureza através do trabalho o que implica a compreensão da categoria práxis $^{34}$, que será aprofundada no Capítulo III. Para Marx o trabalho humano produziria a primeira natureza e as relações humanas a segunda natureza. Esta é uma possibilidade teórica adequada para explicar a produção da natureza no capitalismo. Isto implica a possibilidade de se avançar a discussão sobre meio-ambiente e natureza que aparecem articulados no âmbito da Geografia Escolar e que assim se apresentam na contemporaneidade, quando está em jogo a destruição de aspectos vitais da primeira natureza, comprometendo as condições da segunda.

Por outro lado Sociedade, segundo Visentini e Vlach:

É um agrupamento de indivíduos que vivem de acordo com determinadas regras, num certo espaço geográfico. Temos vários exemplos de sociedade: das abelhas, das formigas, a sociedade humana, etc. Em Geografia, nosso interesse é voltado para a sociedade humana, pois é ela que modifica profundamente a natureza e constrói o espaço geográfico (1991: 15).

A concepção marxista permite que se possa compreender a análise geográfica que entende a sociedade através do trabalho, transformando a natureza, em função de suas necessidades de sobrevivência e como, com isso, se

${ }^{34}$ Práxis: atividade material humana, transformadora do mundo e do próprio homem. Essa atividade real, objetiva, é, ao mesmo tempo, ideal, subjetiva e consciente. Insistimos na unidade entre a teoria e a prática, unidade que implica também em certa distinção e relativa autonomia. "[...] é a atividade pela qual o homem se produz ou se cria a si mesmo" (VAZQUEZ, 1977: 407) 
transforma. É uma concepção igualmente relevante para a análise da construção do espaço geográfico. Esse conjunto de possibilidades teóricas é fundamental para subsidiar o trabalho pedagógico no ensino da Educação Infantil no eixo Conhecimento de Mundo - Natureza e Sociedade.

Voltando ao RCNEI, em Considerações Gerais, é apresentada uma a crítica ao resultado do trabalho disciplinar que se desenvolve em Educação Infantil e os impactos que acabam causando, nem sempre favoráveis à formação das crianças.

O documento considera que a organização curricular dessa etapa da educação, quando valoriza o ensino de conteúdos com a finalidade de atender ações preparatórias para as etapas posteriores de escolarização, acaba impedindo o acesso das crianças a experiências mais significativas ao momento formativo que vivem.

Em geral em práticas pedagógicas assim organizadas observa-se 0 desenvolvimento de atividades que recorrem ao copiar, colorir modelos prontos, vinculando-os a um repertório de datas e eventos que acabam estabelecendo marcas fixas no percurso formativo.

O documento pondera que essa prática pode resultar na disseminação de preconceitos através de estereótipos. De fato, a observação das atividades de uma escola cuja concepção seja esta, revela situações que envolvem cenas que nos alcançam no cotidiano.

Quando chegamos ao "Dia do Índio", vemos sair de cada escola ao final do período, uma multidão de indiozinhos cujo cocar tem apenas uma pena. É a típica atividade que estereotipa o homem indígena, suas diversas etnias e sua cultura. Quando não tratados em profundidade (no planejamento) esses temas colocam a escola frente ao risco de ela mesma, inadvertidamente, difundir estereótipos indesejáveis que contrariam o conhecimento histórico, geográfico, científico enfim. 
A criança tem direito ao ensino escolar, a partir de uma perspectiva científica, filosófica e estética, que Ihes garante os meios de comunicar-se e atuar no cotidiano de forma ativa, crítica.

Outro aspecto importante, apontado no documento, com relação as representações que tradicionalmente as instituições de ensino fazem das crianças, é relativo a idéia de um planejamento de conteúdos que parte de conjuntos simples de informações para avançar para níveis mais complexos. Esta forma de conceber e propor o trabalho pedagógico com as crianças pequenas impede que elas possam expressar os saberes que vêm produzindo através das práticas sociais ou mesmo que possam ser desafiadas a entrar em contato com os fenômenos, fatos e dados da realidade, levantando hipóteses de explicação sobre esse conjunto de observações.

Talvez esta seja a grande diferença entre uma concepção, digamos, mais conservadora, e as possibilidades de concepções que diversos educadores vêm investigando como adequados para a construção de uma perspectiva teórica fundamentada nas teorias sócio histórica, e que estão sintetizadas no documento em análise:

O trabalho com os conhecimentos derivados das Ciências Humanas e Naturais deve ser voltado para a ampliação das experiências das crianças e para a construção de conhecimentos diversificados sobre o meio social e natural. Nesse sentido, refere-se a pluralidade de fenômenos e acontecimentos - físicos, biológicos, geográficos, históricos, e culturais -, ao conhecimento da diversidade de formas de explicar e representar o mundo, a contato com as explicações científicas e à possibilidade de conhecer e construir novas formas de pensar sobre os eventos que a cerca. (RCNEI, 1998: 166). 
Quando Lacoste $(2006,22)$ aponta as conseqüências do que chamou comodismo pedagógico ${ }^{35}$, nos obriga a refletir se, extrapolando suas considerações no campo da Geografia, o mesmo não se aplicaria as Instituições de Ensino de Educação Infantil, quando vimos sua resistência em experimentar novas possibilidades pedagógicas com as crianças, através de uma prática educativa relevante.

E uma prática educativa relevante deve considerar a possibilidade de assegurar meios e condições para que o sujeito em formação esteja num outro lugar após o processo formativo. Isto é a finalidade da educação:

O trabalho com este eixo, portanto, deve propiciar experiências que possibilitem uma aproximação ao conhecimento das diversas formas de representação e explicação do mundo social e natural para que as crianças possam estabelecer progressivamente a diferenciação que existe entre mitos, lenda, explicações provenientes do "senso comum" e conhecimentos científicos. (RCNEI, 1998: 167)

Estabelecidos esses pressupostos o documento apresenta uma reflexão sobre criança, natureza e sociedade. Parte-se da afirmação que, movidas pelo interesse e curiosidade vão observar as regularidades que acontecem no meio com o qual se relacionam. A partir da mediação e da observação dessas regularidades as crianças vão identificar no meio as condições para construir sua experiência e desenvolver atividades física, mental e afetiva o que the resultará na construção de explicações sobre o que vive.

$$
\begin{aligned}
& \text { Quanto menores forem as crianças, mais suas } \\
& \text { representações e noções sobre o mundo estão } \\
& \text { associadas diretamente aos objetos concretos da }
\end{aligned}
$$

35 Comodismo pedagógico: expressão proposta por Lacoste para ponderar sobre os resultados da inércia da ação educativa de professores que praticam uma Geografia que não questiona os ocultamentos estratégicos das razões, necessidades e finalidades do ensino das categorias que permitam a compreensão do espaço a partir do raciocínio geográfico. 
realidade conhecida, observada, sentida e vivenciada. O crescente domínio e uso da linguagem, assim como a capacidade de interação, possibilitam, todavia, que seu contato com o mundo se amplie, sendo cada vez mais mediado por representações e por significados construídos culturalmente. (RCNEI, 1998: 177)

Aqui interessa observar como as representações gráficas expressas através de croquis do ambiente da creche vão ativar as capacidades de observar, identificar, nomear objetos e ambientes representados. Acompanhar o levantamento de hipóteses que as crianças vão construir a partir da interpretação que façam da representação apresentada, para a solução de determinada situação problema proposta.

As relações que se estabelecem em processos que envolvam atividades assim planejadas, é que vão permitir as crianças trazer da complexidade das vivências com seu meio natural e social, as condições para a construção de conhecimento. É com essa hipótese que trabalho quando trago a representação gráfica (croquis) como instrumento de mediação para a organização, planejamento e discussão no âmbito da prática pedagógica. Penso que esta seja uma tarefa fascinante para educadores e geógrafos comprometidos com a perspectiva de um fortalecimento de uma educação de qualidade.

Os objetivos propostos para o eixo Natureza e Sociedade, expressos no documento, são importantes para o trabalho do professor e para a construção do projeto pedagógico da Instituição de Ensino. Colaboram para que as áreas do conhecimento reconheçam o foco de sua contribuição. Eles estão são assim formulados:

- Explorar o ambiente, para que possa se relacionar com pessoas, estabelecer contato com pequenos animais, com plantas, e com objetos diversos, manifestando curiosidade e interesse. 
- Interessar-se e demonstrar curiosidade pelo mundo social e natural, formulando perguntas, imaginando soluções para compreendê-lo, manifestando opiniões próprias sobre os acontecimentos, buscando informações e confrontando idéias;

- Estabelecer algumas relações entre o modo de vida característico de seu grupo social e de outros grupos sociais;

- Estabelecer algumas relações entre o meio ambiente e as formas de vida que ali se estabelecem, valorizando sua importância para a preservação das espécies e para a qualidade da vida humana. (RCNEI, 1998: 175).

Ao considerar os objetivos é importante ressalvar que estes não podem ser tomados como prescrição, devendo ser adequados as condições do trabalho educacional de cada Escola, para que não se estabeleçam metas contraditórias entre as necessidades de formação das crianças e aquilo que seria apenas um conjunto de diretrizes das práticas pedagógicas.

Tal aparente prescrição pode levar ao equívoco de se moldar a formação das crianças, considerando o ponto de chegada. A exploração do ambiente é das atividades mais essenciais na construção da identidade da criança. Caberá a cada escola planejá-las de forma significativa.

Feitas estas ressalvas quero retomar o documento e apontar o que ali se considera "conteúdo". Para cumprir a finalidade de registrar aspectos relevantes do documento, optei por trabalhar com itens, através dos quais apresento os chamados conteúdos que subsidiaram a construção da atividade do estudo de caso. Antes, apresento os critérios levados em conta para propô-los.

Critérios: relevância e vínculo com as práticas sociais significativas; grau de significado para a 
criança; possibilidade que oferecem de construção de uma visão de mundo integrada e relacional; possibilidade de ampliação do repertório de conhecimentos a respeito do mundo social e natural. (RCNEI, 1998: 177)

Esses critérios, provavelmente, não são definitivos, suficientes ou norteadores de outras opções para a construção da organização curricular. Mas considero, como já discuti anteriormente, que expressam um momento histórico importante. $\mathrm{Em}$ alguns contextos acabam sendo um documento de consulta quase que exclusivo. Mais que os próprios conteúdos podem contribuir para que cada Instituição acrescente conteúdos importantes, significativos para sua realidade.

Critérios para a escolha de conteúdos na Educação Infantil: uma discussão do interesse da Geografia?

Os "conteúdos" que permitem construir um eixo, definir um tema destinado ao trabalho educativo, só podem estar previstos na matriz curricular de cada escola e se for significativo para a criança. Ocorre que os significados e os sentidos desses conteúdos não podem ser compreendidos, apenas, considerando-se estritamente o foco da criança na atividade de momento.

O grau de significado de um conteúdo para a criança emerge da mediação implicada no processo formativo. A criança aprende a valorizar os conteúdos a partir dessa mediação/interação. Os conteúdos que podem ser organizados a partir do conhecimento científico, de modo geral, são sempre muito relevantes para a criança, pois se referem a fenômenos e ocorrências de seu contexto e vivências.

Uma leitura apressada deste critério pode resultar no reducionismo dos conteúdos que se planeja para o trabalho educacional. Esse reducionismo ocorre se só se conta com as situações de rotina organizadas em torno de um rol fechado de conteúdos ou caso se considera que as crianças não estariam prontas para entrar em contato com novos conceitos que vão tornando complexo o percurso formativo. 
A possibilidade de um conteúdo permitir a construção de uma visão de mundo integrada e relacional parece constituir-se num critério central para a inclusão das atividades envolvendo a representação gráfica dos espaços de vivência da criança, através das atividades planejadas na escola. Essa visão de mundo integrada e relacional inclui o raciocínio geográfico para explicar e interpretar o espaço vivido.

Vamos retomar Lacoste para pensar a convergência entre esse critério e o que ele defendia como essencial para romper com as limitações impostas por uma Geografia Escolar equivocada que comprometia o ensino, a formação conceitualmente adequada.

Imaginar que é possível considerar o ensino dos elementos que caracterizam o espaço físico suficiente para a formação dos educandos tem sido o maior equívoco da Geografia Escolar. Mas imaginar que seja suficiente tomar os aspectos relevantes da geopolítica em relação ao espaço natural também não é suficiente para o ensino da Geografia.

O critério proposto no RCNEI que aponta relevância e vínculo com as práticas sociais significativas também faz convergir o que diz Lacoste e o que dizem os documentos. Em A Geografia..., o autor apresenta uma longa reflexão sobre a relevância social dos conhecimentos geográficos e os aspectos em que deveriam interessar aos cidadãos. Mais que isso alerta para a importância desse conhecimento como estratégico. Aponta os vínculos desses conhecimentos com as práticas sociais significativas, mas, sobretudo, alerta que há ações de poder que se prevalecem do conhecimento geográfico, como vimos anteriormente, o que está para além das práticas sociais no cotidiano.

Lacoste aponta uma dimensão política tanto para a ação do geógrafo como para a ação do professor de geografia. E é disto mesmo que se trata. O RCNEI entra num campo do debate educacional que reconhece a Educação e a prática educativa em sua dimensão política. Isto, discutimos no Capítulo I. 
Diante da necessidade de fazer escolhas sobre o que ensinar se deve decidir a partir da indagação do que fará toda a diferença para o percurso formativo de jovens e crianças e para o percurso profissional docente.

Penso que buscar na Geografia Escolar elementos para discutir o que ensinar em Natureza e Sociedade, como parte daquilo que se pode construir em Conhecimento de Mundo, exige uma tomada de posição sobre a diferença entre ensinar o espaço vivido e efetivamente criar condições para as crianças construírem o espaço geográfico.

Nisto o papel do professor e da escola são decisivos. Em geral se entende que ensinar de forma significativa e partir de vínculos com as práticas sociais significativas remete ao estudo do meio local. Creio que este tem sido um equívoco quando se trata de ensinar sobre o contexto em que vive a criança. Vejamos algumas ponderações de Lacoste, ainda muito pertinentes:

Para ir ao encontro das enumerações de rubricas e das nomenclaturas, o estudo do "meio local", aquele onde se encontra a escola, foi preconizado como "procedimento de estímulo", notadamente no ensino primário. Mas ali também se afirma que ensinar a Geografia não é coisa fácil, e talvez mais ainda por esses métodos ativos. O estudo do meio local, para ser frutífero, exige a reunião de condições que são, a bem dizer, bastante excepcionais: tempo, entusiasmo, mestres solidamente formados que sejam capazes de operar múltiplas comparações e de serem pesquisadores perspicazes e bons observadores do terreno. (2006: 248)

Esta reflexão nos trás imediatamente a prática que temos observado no ensino das escolas. Para conhecer a Natureza e a Sociedade, considera-se importante a realização do estudo do meio, como parte de metodologias que 
pretendem tornar o ensino significativo, interdisciplinar, suficiente para a formação da criança numa perspectiva que consolide uma cidadania ativa.

Quero ponderar que, de fato, esses recursos não são suficientes. O estudo do meio pressupõe a formação do professor, o trabalho da equipe pedagógica, e os procedimentos da gestão escolar que assegure os recursos adequados ao seus procedimentos evitando a improvisação que leva ao reducionismo conceitual.

A escola tem necessidade de recorrer aos conhecimentos geográficos para afirmar sua presença no âmbito das práticas sociais significativas do lugar em que se insere. A gestão pedagógica da escola deve produzir suas cartas, compreender como ela mesma distribui fluxos e faz convergir para ela outros tantos. Isto é essencial para que o professor possa realizar o estudo do meio.

[...] sem isso, e é bem freqüente o caso, não se trata senão de propósitos descozidos, enumerando alguns aspectos de um quadro bem familiar aos alunos para que eles tenham interesse nisso (Lacoste, 2006: 249).

A propósito do objeto da Geografia, entendo que a escola não pode esperar dos docentes um ensino significativo se não se torna uma referência e um lugar em que as práticas escolares pertençam ao âmbito das práticas sociais globais, o que inclui as espacialidades. A cultura escolar pode articular-se com os saberes da comunidade para produzir o saber pensar e interpretar o espaço.

As possibilidades de ampliação do repertório de conhecimentos a respeito do mundo social que a escola deve garantir às crianças, deve garantir a si mesma, enquanto instituição que aprende, também, através de seus professores, de seus alunos, das famílias, dos moradores do entorno enfim.

Não podemos enumerar critérios e respectivos conteúdos sem observar que, por vezes, estes fazem sentido para, apenas, parte daqueles que se relacionam com a escola. A Geografia pode constituir processos de construção 
do conhecimento que ampliem os repertórios de saberes incluindo a todos. Vamos pensar sobre isto, observando o que o RCNEl sugere como conteúdo para o eixo Natureza e Sociedade.

Organizando "os blocos de conteúdos": arranjos possíveis

Para a faixa etária de zero a três anos, o RCNEl não propõe conteúdos propriamente. Registro as idéias chave para o desenvolvimento de atividades com as crianças dessa faixa etária, para situar a criança de três anos, que, nas instituições de ensino está separada das crianças de quatro a seis anos. Mas que neste estudo de campo participa da atividade.

Essas idéias estão assim organizadas: participação em atividades que envolvam histórias, brincadeiras, jogos e canções que digam respeito às tradições culturais de sua comunidade e outros grupos; exploração de diferentes objetos, de suas propriedades e de relações simples de causa e efeito; contato com pequenos animais e plantas; conhecimento do próprio corpo por meio do uso e da exploração de suas habilidades físicas, motoras e perceptivas.

Para as crianças de quatro a seis anos organizam-se blocos que abordam "Organização dos grupos e seu modo de ser, viver e trabalhar"; "O lugar e suas paisagens"; "Objetos e processos de transformação"; "Os seres vivos" e fenômenos da natureza" (RCNEI: 181-184).

Analiso o bloco Lugares e Paisagens, pois aí está o âmbito no qual a Geografia Escolar pode contribuir, ao participar do debate que se abre em muitas direções e que envolve questões curriculares para a Educação Básica, o papel da Ciência na Educação, as disciplinas escolares e sua relação com as disciplina acadêmicas.

A Geografia Escolar cabe participar de processo de mediação na construção do conhecimento e uma das hipóteses que sustento nesta pesquisa é que a Geografia pode realizar essa mediação a partir das possibilidades de seu objeto de estudo, fundamentando a organização de atividades para as crianças, que 
criem oportunidades de construir experiências adequadas aos seus interesses, naquilo que se refira ao espaço, sua construção, produção e reprodução.

As possibilidades interdisciplinares da prática pedagógica na Educação Infantil devem garantir o direito que a criança tem de perguntar, indagar, questionar, encantar-se. É essencial que a Escola possa responder a esses encantamentos. E responder a altura do direito da criança em ter acesso a muitas possibilidades de resposta.

\section{O Lugar e Suas Paisagens}

Tanto quanto o documento, tomo a abordagem desse bloco respeitando a forma didática como aparece, lembrando que há outras possibilidades de arranjo. Antes de indicar os conteúdos propostos faço duas ressalvas, que tornam a leitura e interpretação dos excertos que vou utilizar, mais justas e corretas, de acordo com o que ali está proposto.

Os autores alertam para o formato didático da organização dos conteúdos, mas lembram que os conteúdos devem ser tratados de forma interdisciplinar evitando a fragmentação destes no processo de ensino. E apresentam antes de qualquer conteúdo específico o conjunto de procedimentos que consideram essenciais ao desenvolvimento da prática educativa e pedagógica requeridas para o processo ensino-aprendizagem em questão.

Vale a pena apontar tais procedimentos:

- Formulação de perguntas;

- Participação ativa na resolução de problemas;

- Estabelecimento de algumas relações simples na comparação de dados;

- Confronto entre suas idéias e as de outras crianças;

- Formulação coletiva e individual de conclusões e explicações; 
- Sobre o tema em questão;

- Utilização, com ajuda do professor, de diferentes fontes para buscar informações, como objetos, fotografias, documentários, relatos de pessoas, livros, mapas etc.;

- Utilização da observação direta e com uso de instrumentos, como binóculos, lupas, microscópios etc., para obtenção de dados e informações;

- Conhecimento de locais que guardam informações, como bibliotecas, museus etc.;

- Leitura e interpretação de registros, como desenhos, fotografias e maquetes;

- Registro das informações, utilizando diferentes formas: desenhos, textos orais ditados ao professor, comunicação oral registrada em gravador etc. (RCNEI, 1998: 181)

Destaco o procedimento de uso do mapa na situação de ensino. Ele está apresentado como fonte de informação, o que ele efetivamente é. Mas vamos lembrar que estamos construindo este conjunto de referências para investigar se a representação gráfica como os croquis de localização, não constituem um conjunto de conteúdos que devem ser abordados conceitualmente, resultando na construção do raciocínio geográfico. Deixemos esta questão apresentada como hipótese.

\section{Os conteúdos do bloco denominado O Lugar e suas Paisagens}

- Observação da paisagem local (rios, vegetação, construções, florestas, campos, dunas, açudes, mar, montanhas, etc.)

- Utilização, com ajuda dos adultos, de fotos, relatos e outros registros para a observação de mudanças ocorridas nas paisagens ao longo do tempo;

- Valorização de atitudes de manutenção e preservação dos espaços coletivos e meio ambiente. 
A simples observação da paisagem local, conforme a proposta, recorre aos conceitos de uma Geografia que praticou a acomodação pedagógica (nos termos de Lacoste) fazendo permanecer a idéia de que a paisagem se observa.

Creio que a crítica relevante a esse bloco de conteúdos está em se reconhecer os riscos de reducionismo de um trabalho que pressuponha a observação da paisagem local como critério de procedimento didático. A atuação da criança no Lugar é um aspecto mais que essencial para garantir os processos formativos, como veremos ao discutir as questões do desenvolvimento e da aprendizagem. É necessário assegurar às crianças as condições de pleno desenvolvimento de suas capacidades incluindo aquilo que constitui seus saberes, curiosidades, modos de se relacionar com o meio.

Vemos aí a inferência de que a criança pequena está determinada a vivências locais e limitadas. Lembro que a criança atua e convive com escalas múltiplas que the são oferecidas concomitantemente, local e globalmente, através das mídias (da TV, das imagens diversas, da produção artística, da literatura).

O que falta nesse primeiro conjunto de conteúdos é o reconhecimento dessa simultaneidade de interações entre as escalas geográficas o que inclui, logicamente, os espaços da escola como um lugar de vivência das crianças, a partir do qual elas devem ter acesso a outras representações de lugares $e$ paisagens, o que ocorrerá a partir de espacialidades diferenciais, conforme conceituação de Lacoste, que compete a Instituição de Ensino oferecer através da ação educativa, intencional. Planejada.

Ao mesmo em tempo em que a escola desenvolva esse trabalho intencionalmente haverá um conjunto de desdobramentos que poderão resultar na iniciativa, interesse e curiosidade das crianças por indagar, questionar, desvelar espaços diversos que já não sejam relativos ao seu lugar e suas paisagens, conforme o documento propõe. 
A esta questão segue-se outra que tem a ver com o segundo subconjunto de conteúdos: ali se recomenda a utilização de materiais diversos para a observação, novamente, de mudanças ocorridas ao longo do tempo nas paisagens.

Novamente parece que estamos lidando com conceitos limitados e limitantes. A criança participa das mudanças nos espaços em que vive. É preocupante que se "recorte" de sua vivência conceitos geográficos para construir atividades que deveriam relacionar-se diretamente com suas experiências.

É neste ponto que entendo, inclusive, que os croquis de localização são instrumentos de das construções conceituais que podem garantir mais eficazmente a experiência de se constatar as mudanças espaciais em função da organização da vida humana, articulando Natureza e Sociedade.

No trabalho de campo que realizei pude me defrontar com essas questões. Além de alguns equívocos de interpretação que propostas como essa suscitam, as Instituições de Ensino encontram dificuldades para recorrer aos fundamentos conceituais da Geografia Escolar, para a construção de uma perspectiva didática para o trabalho com Lugar e Paisagem.

É importante pensar, então, como conceitos construídos pela Geografia Escolar, e em torno dos quais há relativo consenso a partir da reflexão dos pesquisadores que se dedicam a investigar o ensino escolar, podem ser apropriados pelo processo de fundamentação didática para subsidiar as práticas pedagógicas, da Educação Infantil.

Cavalcanti (2001) dedicou-se a pesquisar as representações sociais que alunos e professores trazem dos conceitos geográficos com os quais identificam a Geografia, no Ensino Fundamental e Médio. Em seguida apresentou uma conceituação científica, que buscou estabelecer, desse ponto de vista, referências para a Geografia Escolar.

Creio que para a discussão didática que está implicada no debate sobre o processo de ensino, a partir de croquis de localização, essa possibilidade 
conceitual seja essencial. A seguir, tomando o trabalho de Cavalcanti (2001) como referência, incorporo os conceitos de lugar, paisagem, território, espaço, sociedade e natureza, para retomar, em seguida o bloco O Lugar e suas Paisagens, no RCNEI, ampliando alguns questionamentos sobre os conteúdos aí organizados.

\section{LUGAR}

A primeira questão relevante diz respeito a se reconhecer que o lugar não pode ser entendido como simples elemento de localização, através do mapa, o que serviria a compreensão e descrição de suas características e peculiaridades.

Cavalcanti (2001) identifica três perspectivas para a construção do conceito de lugar. A primeira é a perspectiva da Geografia Humanística, uma segunda baseada nas concepções histórico-dialéticas e uma terceira baseada nas concepções pós-modernas.

Lugar, na perspectiva da Geografia Humanística, seria o "espaço que se torna familiar ao indivíduo, é o espaço do vivido, do experienciado" (CAVALCANTI, 1996: 89). Nessa perspectiva o espaço é, a princípio, "indiferenciado tornandose lugar na medida em que o sujeito o conhece dotando-o de valor, nos momentos em que cessa o movimento sobre esse espaço" (TUAN; apud CAVALCANTI, 1996: 89).

Essa idéia de lugar como resultado do processo de movimentação sobre o espaço implica em se estudar as relações das pessoas com a natureza (igualmente atribuídas a Tuan) e que caracterizam a Geografia Humanística.

Na perspectiva histórico-dialética, proposta por Cavalcanti (1996), especifica-se uma discussão de lugar no bojo do debate sobre as possibilidades da globalização, que aqui é formulada por Santos (1996; apud RIBEIRO, 2002):

Não existe um espaço global, mas, apenas, espaços da globalização. [...] O Mundo, porém, é apenas um conjunto de possibilidades, cuja efetivação depende 
das oportunidades oferecidas pelos lugares. [...] Mas o território termina por ser a grande mediação entre o Mundo e a sociedade nacional e local, já que, em sua funcionalização, o 'Mundo' necessita da mediação dos lugares, segundo as virtualidades destes para usos específicos. Num dado momento, o 'Mundo' escolhe alguns lugares e rejeita outros e, nesse movimento, modifica o conjunto dos lugares, 0 espaço como um todo. É o lugar que oferece ao movimento do mundo a possibilidade de sua realização mais eficaz. Para se tornar espaço, o Mundo depende das virtualidades do lugar (SANTOS, 1996: 271).

Essa discussão trazida por Ribeiro, a partir da obra de Milton Santos, revela a compreensão de que os lugares materializam os processos da globalização. Em Por uma Outra Globalização, Santos (2003) afirma:

A multiplicidade de situações regionais e municipais, trazida com a globalização, instala uma enorme variedade de quadros de vida, cuja realidade preside o cotidiano das pessoas e deve ser a base para uma vida civilizada em comum. Assim a possibilidade de cidadania plena das pessoas depende de soluções a serem buscadas localmente, desde que, dentro de uma nação, seja instituída uma federação de lugares, uma nova estruturação político-territorial, com a indispensável redistribuição de recursos, prerrogativas e atribuições (SANTOS, 2003: 113).

Esta perspectiva é bastante relevante não só para construir o conceito de lugar, mas para compreender algumas possibilidades educacionais que identificamos no estudo de campo, ocorrido em Diadema, onde a valorização do lugar como 
critério de organização da participação popular tem sido objeto das experiências administrativas do campo democrático popular, desde 1992.

Voltaremos a essa questão, mas ali, de fato, o lugar tem sido uma instância de decisão e tem originado a definição de políticas públicas ao longo desses anos de experiência da participação popular no governo.

A terceira perspectiva trazida por Cavalcanti aponta a concepção Pós-Moderna para definir lugar. Silveira (1993) afirma:

Essa ruptura com a lógica da totalidade significa um rompimento do caminho único, da idéia de uma sociedade total. A partir desse fim da racionalidade totalizante, a proposta é a valorização do empíricoindividual, que se faz através da consideração de outras racionalidades. Em cada situação, no tempo e no espaço, existe "um outro da razão" dentro da razão [...], isto é, várias razões possíveis. Nessa concepção, dado empírico deixa de ser um momento explicado a priori pela totalidade, para ser o eixo da nova epistemologia. (SILVEIRA, 1993: 232; apud CAVALCANTI, 2001: 90).

Portanto, lugar, a partir dessa concepção, deveria ser compreendido em sua dimensão micro, desfeitas as relações com a totalidade, privilegiando as individualidades e os aspectos fragmentários imediatos.

Para o ensino, embora não se possa ignorar estas perspectivas, Cavalcanti aponta uma articulação entre o conceito de Lugar da Geografia Humanística e a representação social dos alunos e professores, sobre esse conceito. Argumenta que, para alunos e professores, "é importante avançar da idéia de lugar vivido para a compreensão de que lugar só pode ser entendido como expressão da totalidade, inacabada, aberta e em movimento o que leva para a compreensão do concebido". (CAVALCANTI, 2001: 91). Acrescenta a formulação de Mello de 
"que lugar, recortado afetivamente, emerge da experiência e é um mundo ordenado e com significado". (MELLO; apud CAVALCANTI, 2001: 91).

Este conceito é bastante adequado para pensar a questão do lugar no âmbito do ensino na Educação infantil. Todavia é necessário pensar o espaço conceitualmente para se propor esta referência. Quanto a isso, Cavalcanti, a partir de Yi-Fu Tuan, propõe:

O espaço pode ser entendido como indiferenciado, e este se transforma em lugar na medida em que é conhecido e dotado de valor (e aí eu incluiria os valores negativos), portanto, ao tornar-se familiar. (2001: 93).

Esta é uma questão essencial para o ensino. As abordagens didáticas que propõe a inclusão de saberes prévios dos alunos, como condição da aprendizagem significativa, deixam de levar em conta que o lugar em que vive o aluno nem sempre traz valores afetivos de harmonização com este. No lugar, mesmo que familiar, as crianças e jovens lidam com estranhamentos que se expressam ali, mas foram trazidos pelo processo de globalização. Creio que o exemplo mais expressivo disto é a abertura de Lan-Houses, por toda a periferia das grandes cidades. Os fenômenos de violência urbana, por outro lado, também constituem o lugar e a escola é instância privilegiada para problematizar essas características para além de observá-las.

Para pensar a questão do ensino de lugar como conteúdo da Educação Infantil considero importante partir dos vínculos de afetividade das crianças, aí construídos, e tomar essas vivências como base para trazer outras referências, trabalhando com clareza pedagógica as manifestações efetivas de cada criança sobre sua experiência.

O próprio RCNEl, quando propõe os procedimentos didáticos, inclui as perguntas, indagações, levantamento de hipóteses que as crianças trazem como essenciais ao processo ensino-aprendizagem. Esses procedimentos 
vinculados ao trabalho com as representações gráficas garantem a criança acesso a condições de interpretação do Lugar e suas paisagens, significativa, como vão indicar os resultados do estudo de caso.

\section{PAISAGEM}

O conceito de paisagem, embora não exclusivo, tem constituído o objeto de estudo da Geografia. Predomina por um longo período o conceito positivista de paisagem, proposto pelas escolas positivistas, das quais se destaca a Geografia alemã e a francesa.

Paisagem já definiu uma unidade espacial passível de observação e descrição (perspectiva da Geografia alemã) e uma variação desta concepção em que se considera a dinâmica constituinte do conjunto espacial (na tradição da Geografia francesa). Nas duas possibilidades conceituais entende-se a paisagem como a expressão material do mundo e sobre a qual ocorre a atividade humana.

O aprofundamento da pesquisa levou ao surgimento do conceito de região, na tradição neopositivista, incorporando paisagem como dimensão dos processos que a constituem, o que facilitaria a metodologia de trabalho dessa concepção, voltada para os levantamentos quantitativos de análise.

$\mathrm{Na}$ tradição marxista, paisagem também foi tomado como conceito pertencente ao âmbito da região, produto territorial das contradições entre capital e trabalho.

Para Bertrand (2003),

a paisagem não é a simples adição de elementos geográficos disparatados. É uma determinada porção do espaço, resultado da combinação dinâmica, portanto instável, de elementos físicos, biológicos e antrópicos que, reagindo dialeticamente uns sobre os outros, fazem da paisagem um conjunto único e 
indissociável, em perpétua evolução. (BERTRAND, 2003; apud SCHIER: 2)

Com a definição de Bertrand, inclui-se a idéia de combinação entre a paisagem cultural e a natural, não sendo possível distingui-las. Há na definição a idéia de conjunto. A concepção que articula Natureza e Sociedade decorre dessa formulação teórica.

Outras formulações, entretanto, surgem e destaco a proposição de Sauer (apud SCHIER, 2003: 3) que verticaliza a idéia de conjunto, trazida por Bertrand, para falar em relações que associam tempo e espaço, resultando na idéia de paisagem construída e transformada no processo de desenvolvimento, com alternâncias entre dissolução e substituição.

A partir da idéia de dissolução e substituição Sauer argumenta que a atividade humana ocorreu num conjunto morfológico sobre o qual, a partir de determinado momento histórico e cultural, o homem interviu. Portanto, segundo esse autor, é possível falar-se em paisagem natural e cultural.

O debate em torno dessa distinção avança com as ponderações de Claval (1999: 420) que vai considerar a organização do espaço contemporâneo, e suas tensões, como resultado da dinâmica cultural. Isto estabeleceria vínculos decorrentes da transformação da paisagem pela ação humana, surgindo uma paisagem peculiar aos diversos grupos e culturas.

Nesta perspectiva a paisagem física deixa de ter importância mais central. Supera-se a idéia de interação entre homem e natureza e pondera-se sobre a humanização da paisagem pelo pensar e não somente pela ação, o que significa uma atuação do homem sobre a paisagem baseada em idéias e interpretações.

Esta corrente avança no sentido de propor uma possibilidade teórica relativa a representação cultural da paisagem. Aqui ela é tomada como uma categoria estética, sobre a qual se pode refletir considerando-se as formas de sua 
representação. Os mapas, a pintura, os croquis são a expressão desses olhares diversos que permitem outros modos de estudar e conhecê-la.

Estas formulações contribuem para a necessária compreensão e problematização do conceito. Mas não seriam suficientes para os processos de transposição didática, pensando o ensino. Para isto a pesquisa de Cavalcanti (2001) recorrendo a Santos aponta:

Para a construção do conceito de paisagem no ensino de Geografia, concordando com Santos, é importante considerar esse conceito como primeira aproximação do lugar, chave inicial para apreender as diversas determinações desse lugar. A partir daí, a análise poderia se encaminhar para o entendimento do espaço geográfico, através de sucessivas aproximações do real estudado. Sendo assim, parece adequada a reflexão sobre esse conceito inserindo elementos como, por exemplo, os sugeridos anteriormente por Santos, desde que não se perca de vista a dimensão objetiva e subjetiva da paisagem e de sua construção (CAVALCANTI, 2001: 99).

O que Cavalcanti considera importante observar a partir da proposta de Santos, diz respeito a elementos que o autor considera essenciais para a análise da paisagem e compreensão do significado do espaço, que transcrevo abaixo:

Cada tipo de paisagem é a reprodução de níveis diferentes de forças produtivas; a paisagem atende a funções sociais diferentes, por isso ela é sempre heterogêna; uma paisagem é uma escrita sobre a outra, é um conjunto de objetos que tem idades diferentes, é uma herança de muitos diferentes momentos; ela é não é dada para sempre, é o objeto de mudança, é um resultado de adições e 
subtrações sucessivas, é uma espécie de marca da história do trabalho, das técnicas; ela não mostra todos os dados que nem sempre são visíveis; a paisagem é um palimpsesto, um mosaico, mas tem um funcionamento unitário e pode ter formas viúvas - à espera de reutilização - e formas virgens criadas para novas funções (SANTOS; apud CAVALCANTI, 2001: 99).

Penso que, sobretudo para a Educação Infantil, a observação desses elementos que permitem a análise e atribuição de significados a paisagem e espaço, respectivamente, transformam-se em diretrizes para a organização das atividades de ensino.

Através dessa construção conceitual pode-se tomar decisões de investigação sobre o Lugar e suas Paisagens, privilegiando-se a pesquisa dessas heterogeneidades; das diversidades da herança histórica escritas sucessivamente através da paisagem; da possibilidade de se construir a esperança das mudanças dado seu caráter transitório e ao mesmo tempo histórico que se faz permanente através de marcas do mundo do trabalho, da técnica; da sua condição essencial de, por força de suas subjetividades; construir e transformar identidades. Esta concepção favorece o trabalho com o segundo grupo de conteúdos que enunciamos acima, para a Educação Infantil.

Para concluir é importante retomar a idéia de que na Educação Infantil será possível organizar os blocos de conteúdos por eixos temáticos tomando os conceitos geográficos como orientadores do trabalho didático-pedagógico. Esta dimensão pertence ao campo da formação docente e da educação continuada. Não será objeto de aprofundamento neste trabalho.

Entretanto, é fundamental sublinhar que sem a introdução de um aparato conceitual na formação docente, transpostos do campo da Geografia Escolar, fica comprometida a formação das crianças, em bases pertinentes e coerentes com as finalidades da etapa de ensino em questão. 


\section{CAPÍTULO III - A TEORIA SÓCIO-HISTÓRICA: CONTRIBUIÇÕES DE VYGOSTKY PARA PENSAR A EDUCAÇÃO}

Nos capítulos anteriores, destaquei aspectos fundamentais das políticas educacionais da década de 90, refletindo sobre o RCNEI com a finalidade de debater os arranjos curriculares na Educação Infantil. A partir daí apresentei uma reflexão sobre as contribuições do campo que passei a nomear Geografia Escolar no âmbito dos arranjos curriculares da Educação Infantil, destacando o eixo Natureza e Sociedade, formalizado no Volume III do RCNEI, Conhecimento de Mundo.

Neste capítulo, procuro identificar instrumentos/referências conceituais para a análise da atividade de campo que permitam compreender a criança e as circunstâncias, as condições em que aprende e se desenvolve. Proponho, ainda, uma reflexão sobre como o processo de ensino e as condições de organização da instituição podem ser decisivos para esse aprendizado e desenvolvimento.

\section{A aprendizagem e o desenvolvimento da criança, na Educação Infantil}

Para aprofundar a necessária discussão sobre aprendizagem e desenvolvimento, essenciais para a análise dos dados coletados através do estudo de caso, faço uma referência histórica, para situar os pesquisadores que propuseram as teorias que aqui tomo como referência.

Dentre os importantes cientistas do século $X X$ que pesquisaram 0 desenvolvimento humano e a aprendizagem estão os membros do Instituto de Moscou, destacando-se Vygotsky e seus principais colaboradores, Luria e Leontiev. 
A produção desses teóricos ocorreu em conjuntura política diversa daquela que se observava no Ocidente capitalista. O trabalho desse grupo ocorre num período revolucionário que se desenvolvia na Rússia desde o final do século XIX. ${ }^{36}$

O trabalho de pesquisa de Vygotsky buscava encontrar fundamentos para explicar o homem como um ser capaz de promover sua emancipação das condições a que está sujeito nas sociedades de organização social baseada na divisão de classes.

Com Luria e Leontiev, companheiros no Instituto de Psicologia de Moscou procurou rever as bases teóricas da Psicologia, buscando a melhor abordagem dos aspectos essenciais, caracteristicamente humanos. Vygotsky procurou basear os métodos de construção de sua pesquisa no materialismo dialético, o que resultou no reconhecimento de que havia relações entre o desenvolvimento psíquico e os processos históricos e culturais reais que o determinam.

\section{Elementos da teoria sócio-histórica}

Para Vygotsky o papel do observador humano na pesquisa científica deveria ser minimizado. Reconhecendo a crise na psicologia experimental que não alcançava as condições para explicar as funções psicológicas mais complexas do ser humano, apontava os riscos de uso de uma metodologia eclética e de uma perspectiva positiva que não "chegava a produzir descrições desses processos complexos em termos aceitáveis para a Ciência" (OLIVEIRA, 1995: 22).

Assim, pôs-se a trabalhar numa perspectiva que pudesse integrar o homem "enquanto corpo e mente, enquanto ser biológico e ser social, enquanto membro da espécie humana e participante de um processo histórico" (OLIVEIRA, 1995: 22).

36 A revolução russa, que se efetiva em 1917, é amadurecida em condições sociais, políticas, econômicas e culturais bastante peculiares. É importante relembrar brevemente alguns aspectos que possam situar o trabalho dos cientistas alinhados a pesquisa, cuja finalidade era a de reconstituir um campo de referências para a condução do processo revolucionário além de refletir sobre seus resultados o que os transformou em importante alternativa à compreensão dos processos de aprendizagem e desenvolvimento humanos, pelo mundo afora. É nesse contexto que emerge o trabalho de pesquisa no Instituto de Moscou. 
Recorro ainda uma vez a Oliveira para apontar que essa abordagem para a Psicologia, decorrente das teorias propostas por Vygotsky, levou aos fundamentos seguintes:

- As funções psicológicas têm um suporte biológico pois são produtos da atividade cerebral;

- O funcionamento psicológico fundamenta-se nas relações sociais entre o indivíduo e o mundo exterior, as quais se desenvolvem num processo histórico;

- A relação homem/mundo é uma relação mediada por sistemas simbólicos. (OLIVEIRA, 1995: 23; ênfase adicionada)

Para o desenvolvimento da análise dos resultados do trabalho de campo deste estudo, os três pressupostos são relevantes. Para trabalhar a questão da mediação na escola, entretanto, é fundamental que introduza esta reflexão como pressuposto essencial.

Sem esgotar a possibilidade de definir o que seria mediação, é importante estabelecer algumas considerações que permitam reconstruir esse conceito no âmbito deste estudo. A primeira idéia essencial diz respeito a impossibilidade de o homem ter acesso direto aos objetos pelos quais está cercado e que busca conhecer.

Quando este acesso ocorre, ele se dá através de um recorte de toda a possibilidade real. Os elementos envolvidos nos procedimentos para organizar esse acesso recorrem ao uso de instrumentos e signos que, no caso dos primeiros ajudam a atuar sobre os objetos e no segundo a regular as ações sobre o psiquismo.

A construção do conhecimento, assim mediada, não é o resultado da ação do sujeito sobre a realidade. Ao contrário é o resultado das relações do sujeito 
mediadas pelos objetos, pela organização dos ambientes, pelo mundo da cultura que permeia suas vivências.

[...] os instrumentos são de dois tipos: técnicos, artefatos fabricados pelo homem para agir sobre a matéria, e semióticos, sistemas de signos inventados por ele para agir sobre as pessoas e sobre si mesmo. De natureza diferente, esses dois tipos de instrumentos têm duas coisas em comum: servir de mediadores nas relações dos homens com o mundo e entre si e conferir à atividade o poder de transformar a realidade. (ANGEL, 2006)

Portanto as relações sociais dos homens entre si e com o mundo se estabelecem no meio cultural onde esses instrumentos técnicos e simbólicos são organizados e acessados pelos sujeitos, tornando-se necessários ao seu desenvolvimento, havendo então uma convergência dos elementos históricos e culturais.

As funções psicológicas superiores, percepção, memória, atenção também serão elementos de mediação entre o homem em suas relações inter e intrapsíquicas, com o seu meio natural e cultural. Para discutir a mediação no âmbito da ação educativa, a abordagem das FPS torna-se fundamental. E é este o ponto que vamos trabalhar a seguir.

\section{A Mediação como pressuposto essencial do desenvolvimento infantil - A ação educativa em foco}

A mediação é um princípio norteador da docência. Já não se trata de optar por uma prática que inclua, intencionalmente, a mediação como estratégia de ensino. Ao contrário, se penso nas intencionalidades da ação docente, vou concluir que a mediação é constituinte do processo de e ensino e aprendizagem do ser humano. Portanto, é importante que no campo da 
educação se considere a mediação e o desenvolvimento da criança, como elementos essenciais ao aprendizado.

A mediação ocorre a partir do momento em que símbolos ou instrumentos "atravessam" a experiência da criança, por meio das relações sociais, introduzindo aí elementos da cultura que vão reorganizar os modos de construção do conhecimento.

Para compreender esse processo é importante introduzir neste momento algumas considerações sobre as funções psicológicas superiores que se estabelecem e complexificam a partir da mediação, promovendo o desenvolvimento.

\section{Percepção}

A percepção é uma das funções psicológicas superiores, próprias do homem. Por muito tempo, a percepção foi entendida exclusivamente como resultado de determinações fisiológicas dos órgãos sensoriais ${ }^{37}$. Entretanto, ampliando essa concepção, Vygotsky vai propor que "a mediação simbólica e a origem sóciocultural dos processos psicológicos superiores são pressupostos fundamentais para explicar o funcionamento da percepção" (OLIVEIRA, 1995: 73).

Embora os aparatos fisiológicos organizem o sistema sensorial, a criança, em suas reiteradas interações com outros sujeitos, irá perceber o meio e suas relações, mediada por "conteúdos culturais" (OLIVEIRA, 1995: 73).

Em Oliveira (1995) encontra-se o exemplo seguinte, que "[...] quando percebo um par de óculos estou identificando-o através dos conteúdos culturais que fui aprendendo a utilizar para reconhecê-lo. Se assim não fosse, seria apenas dois círculos, talvez, presos por hastes".

Objetos, eventos e situações vão atuar sobre o aparato perceptivo permitindo ao sujeito captar o objeto, reconhecendo - o por seus conteúdos culturais. A

37 Conforme aponta Oliveira (1995), quando discute as funções superiores. 
percepção terá sempre um grande impacto nas condições de interpretação das representações gráficas, nas crianças pequenas. Aí a mediação provoca a percepção de signos equivalentes a objetos que conhece na realidade. Disto decorre a importância de se introduzir as representações gráficas que, por meio da percepção, ativam memória e atenção.

A percepção do objeto como um conjunto está relacionada ao processo de desenvolvimento. Para o trabalho pedagógico com as representações gráficas esta função é essencial. Sua ativação cria as possibilidades de a criança perceber situações, objetos que se apresentem em proporções diferenciadas, em condições bi e tridimensionais, o que favorecerá a construção dos conceitos e raciocínio geográficos ao longo de seu desenvolvimento.

\section{Atenção}

Também a atenção se organiza, enquanto função psicológica, a partir de um aparato neurológico determinado. Mas também ela ficará sujeita a mediação simbólica, o que resultará no controle do foco em que será estabelecido. A atenção pode ser voluntária (superior) ou involuntária (primitiva). Os instrumentos e signos de mediação acabam construindo possibilidades de a criança prestar atenção aquilo que é de seu interesse.

Esse processo de seleção das informações, objeto da atenção, resulta na organização das ações. Ao longo do desenvolvimento, a capacidade de dirigir a atenção para o que se considera relevante dependerá das interações com o meio. É possível inferir que a atenção deve ser considerada sempre que se trabalham os processos educativos, a partir da mediação envolvidos na situação do aprendizado, que constitui uma situação social específica.

E importante considerar, porém, que a atenção involuntária continua presente e é ativada sempre que estímulos a impactam. Portanto, compreender a organização dessa função favorece a possibilidade de se conduzir a mediação a partir da sistematização e da intencionalidade envolvidas no processo educativo. 
Memória

A memória é elemento essencial para se compreender "a origem social dos signos e o seu papel crucial no desenvolvimento individual" (VYGOTSKY, 1995: 43). Vygotsky reconhece uma "memória natural que se caracteriza pela retenção das experiências reais como a base dos traços mnemônicos" (VYGOTSKY, 1995: 43) muito próxima da percepção. Por outro lado, aponta "um outro tipo de memória mediada que permite ao individuo controlar seu próprio comportamento, por meio da utilização de instrumentos e signos que provoquem a lembrança do conteúdo a ser recuperado, de forma deliberada" (OLIVEIRA: 1995, 77).

A teoria sócio-histórica considera a experiência humana frente à situaçãoproblema como a oportunidade que garantiu ao homem introduzir um novo elo na relação estímulo-resposta. Quando diante do estímulo que oferece risco e leva a uma experiência de dor, o ser humano irá lembrar-se dessa dificuldade posteriormente.

Diante de experiência semelhante e da eminência da dor, vai evitar repeti-la. É nessa dimensão que terá ocorrido uma mediação pelo objeto/elemento que provocou a dor diretamente.

Se alertado por outro, terá ocorrido uma mediação entre sujeitos. Em ambos os casos, esses elos poderão significar a possibilidade do sujeito controlar seu próprio comportamento. Vygotsky representou esse ato complexo, que envolve estímulo e resposta e o elo de mediação, conforme a representação abaixo:

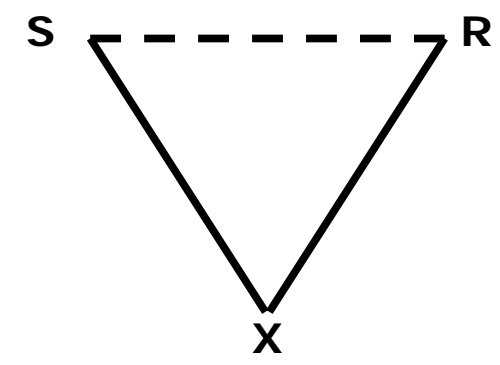

$\mathbf{S}=$ estímulo

$\mathbf{R}=$ resposta

$\mathbf{X}=$ elemento mediador 
O elemento mediador não é apenas mais um elo adicional na cadeia $S-R$, como diz o próprio Vygotsky, e vale acrescentar:

Na medida em que esse estímulo auxiliar possui a função específica de ação reversa, ele confere à operação psicológica formas qualitativamente novas e superiores, permitindo aos seres humanos, com o auxílio de estímulos extrínsecos, controlar o seu próprio comportamento. O uso de signos conduz os seres humanos a uma estrutura específica de comportamento que se destaca do desenvolvimento biológico e cria formas de processos psicológicos enraizados na cultura. (VYGOSKY, 1995: 45)

Os processos psicológicos se estabelecem em processos prolongados e complexos. Esse processo leva a evolução psicológica. Seu enraizamento na cultura aponta que a atividade humana recorre ao uso de signos e instrumentos para realizar-se. Um conjunto de transformações qualitativas que decorrem da construção dos processos psicológicos é que resultarão em saltos que fazem avançar dialeticamente o desenvolvimento, observando-se aí a constituição de funções psicológicas superiores, de origem sócio-cultural.

Não se pode ignorar, entretanto, que há uma linha de desenvolvimento humano dos processos elementares, que tem origem biológica. Para Vygotsky, "a história do comportamento da criança nasce do entrelaçamento dessas duas linhas". Se, por um lado, as raízes biológicas e os arranjos orgânicos garantem o desenvolvimento desses processos elementares, por outro, estão articulados aos comportamentos de uso de instrumentos e da fala humana, o que permite afirmar que "a infância se coloca no centro da pré-história do desenvolvimento cultural" (VYGOTSKY, 2000: 53).

No âmbito dessa articulação vão se formando sistemas psicológicos de transição, o que constituiria a história natural do signo. No âmbito deste estudo, é importante registrar que as pesquisas realizadas pelos soviéticos 
demonstraram que as crianças pequenas, que são sujeitos da atividade de campo que desenvolvi, fazem associações entre palavras e signos totalmente diferentes daquelas presentes nos processos das crianças que já operam em processos cuja complexidade resulta em mais desenvolvimento.

Pode-se reconhecer, então, "um estágio de desenvolvimento intermediário entre o processo elementar e o completamente instrumental" (VYGOTSKY, 2000: 54). Reconhecer que cada criança fará uma trajetória pessoal diferenciada nesses estágios intermediários é muito relevante para o trabalho pedagógico na Educação Infantil.

Pensar, para a criança pequena, significa lembrar. E essa possibilidade ocorre, essencialmente, nessa fase do desenvolvimento infantil. Aí a criança vai estabelecendo relações lógicas. O uso do mapa, dos croquis de localização, que são importantes elementos de mediação, podem favorecer a lembrança.

Porém, mais que isso, os signos favorecem e ativam a lembrança. Uma finalidade didática ao se trabalhar com instrumentos é o de influenciar a relação das crianças com o ambiente, propiciando que o sujeito modifique seu comportamento, colocando-o sob seu controle. A atenção será outra função essencial para a estruturação dessas relações estabelecidas pelas pessoas com o ambiente.

Os Processos de Internalização

Para Vygotsky (1991: 55), "internalização é a reconstrução interna de uma operação externa". As experiências que vão se desenvolvendo interpessoalmente entre a criança e as pessoas de seu convívio acabam por gerar uma compreensão da criança sobre essas vivências. Transformações sucessivas ocorrerão até que os elementos envolvidos nessas ações transformem-se, numa dimensão intrapessoal, em algo que passa a representar um novo momento do desenvolvimento. 
O gesto de apontar é escolhido por Vygotsky para indicar que a princípio a criança muito pequena, estando diante de um objeto que deseja alcançar, esticará as mãos para aproximar-se dele. Provavelmente, outra pessoa a auxiliará nessa aproximação. Essa mediação reiterada acabará resultando no direcionamento do gesto de apontar para a pessoa, numa próxima vez em que a criança queira aproximar-se de algo. Essa experiência nos ajuda a compreender como um conjunto de transformações se seguirá a partir daí.

a) Uma operação que inicialmente representa uma atividade externa é reconstruída e começa a ocorrer internamente.

b) Um processo interpessoal é transformado num processo intrapessoal.

c) A transformação de um processo interpessoal num processo intrapessoal é o resultado de uma longa série de eventos ocorridos ao longo do desenvolvimento (VYGOTSKY, 1991: 64).

Esses enunciados sobre a transformação que decorre do processo de internalização das atividades mediadas sintetizam a demonstração de Vygotsky (1991: 63) de "como o uso de instrumentos amplia de forma ilimitada a gama de atividades em cujo interior as novas funções psicológicas podem operar". E acrescenta:

Nesse contexto, podemos usar o termo função psicológica superior, ou comportamento superior, com referência à combinação entre o instrumento e o signo na atividade (1991: 63).

Vamos retomar a idéia de que instrumento, diferentemente de signo, tem um objetivo explícito ao ser feito ou buscado. Para Oliveira (1995: 29), "ele carrega consigo, portanto, a função para a qual foi criado e o modo de utilização desenvolvido durante a história do trabalho coletivo. É, pois, um objeto social e mediador da relação entre o individuo e o mundo". 
Vygotsky, portanto, trabalha a idéia de função mediadora para o instrumento, que é relativo "ao processo de trabalho para a transformação e controle da natureza, e o papel dos signos enquanto instrumentos psicológicos, ferramentas auxiliares no controle da atividade psicológica" (OLIVEIRA, 1995: 29).

Vimos anteriormente que os instrumentos técnicos e semióticos na atividade permitem a construção e o desenvolvimento das funções ou comportamentos superiores. O que quero destacar aqui é que os mapas, os croquis - que são os esboços de representação gráfica - são instrumentos e sistemas simbólicos que recorrem a signos e a uma linguagem específica.

Parece-me que sua função mediadora, de localização, implica trabalho de orientação, intervenção e controle, na natureza e nos processos culturais, como vimos no capítulo anterior.

Organizar atividades que possam recorrer a representação gráfica, tendo o croqui de localização como foco, pode favorecer as vivências das crianças quanto à sua espacialidade, o lugar onde vivem. Os mapas e croquis parecem constituir conteúdos culturais muito adequados quanto à combinação dos instrumentos e signos para o processo de mediação. Essa combinação possibilita a abordagem das funções psicológicas superiores e permite que se compreenda sua importância no processo de ensino e aprendizagem.

A mediação através de instrumentos e signos favorece e ativa o processo e internalização dos sistemas simbólicos, tornando possível ao homem a possibilidade de construir o conhecimento num processo de socialização intra e interpsicológica, atuando no mundo, fazendo comparações, planejando.

Levanto a hipótese que, de certa forma, a representação gráfica, que se caracteriza por articular os instrumentos técnicos e semióticos através de croquis de localização, pode ativar as capacidades da criança no sentido de sua atuação e deslocamento a partir de novas relações, mais complexas, na medida em que possa conhecer e reconhecer as características de seu lugar. 
Creio que a proposição de Lacoste - de que aos professores caberia romper com o comodismo pedagógico criando as condições para uma ação educativa capaz de romper com os conceitos obstáculos no ensino da Geografia, como anteriormente colocado no Capítulo II - aproxima-se das possibilidades de reflexão na ação educativa que a teoria sócio-histórica permite.

\begin{abstract}
Quando trabalhamos com os processos superiores que caracterizam o funcionamento psicológico tipicamente humano, as representações da realidade exterior são, na verdade, os principais mediadores a serem considerados na relação do homem com o mundo (OLIVEIRA, 1995: 35).
\end{abstract}

É importante ressaltar que o conceito de representação da realidade exterior, enquanto função psicológica superior, não deve se confundir com as representações gráficas. Estas constituem uma linguagem específica, concorrem para a ativação das funções superiores, mas se distinguem conceitualmente das representações da realidade exterior que o homem constrói.

É justamente a origem dessas representações que Vygotsky está buscando quando nos remete à criação e ao uso de instrumentos e de signos externos como mediadores da atividade humana (OLIVEIRA, 1995: 36).

A representação gráfica, aqui, é compreendida como instrumento e signo capaz de favorecer a mediação, na ação educativa, necessária à inserção da criança em atividades planejadas que resultem na mobilização de suas capacidades em favor da construção de seu conhecimento de mundo.

Considerando, então, as categorias que selecionei para refletir sobre as questões do aprendizado e do desenvolvimento infantil - mediação e funções 
superiores - que Vygotsky chamou de novo método ${ }^{38}$-, é importante refletir em que esse novo método impacta a compreensão das bases psicológicas da aprendizagem e do desenvolvimento para se compreender os processos de ensino, desde a perspectiva da mediação.

Sua primeira conclusão foi que o desenvolvimento infantil caracteriza-se por uma "alteração radical na própria estrutura do comportamento; a cada novo estágio, a criança não só muda suas respostas, como também as realiza de maneiras novas, gerando novos instrumentos de comportamento e substituindo sua função psicológica por outra" (VYGOTSKY, 1991: 83).

Portanto, o conceito de desenvolvimento para Vygotsky (1991: 83) rejeita o

$$
\begin{aligned}
& \text { [...] ponto de vista comumente aceito de que o } \\
& \text { desenvolvimento cognitivo é o resultado de uma } \\
& \text { acumulação gradual de mudanças isoladas, para } \\
& \text { afirmá-lo como processo dialético complexo } \\
& \text { caracterizado pela periodicidade, desigualdade no } \\
& \text { desenvolvimento de diferentes funções, } \\
& \text { metamorfose ou transformação qualitativa de uma } \\
& \text { forma em outra, embricamento de fatores internos e } \\
& \text { externos, e processos adaptativos que superam os } \\
& \text { impedimentos que a criança encontra (1991: 85). }
\end{aligned}
$$

Quando Vygotsky identifica pontos de viragem no desenvolvimento da criança está nos indicando que mesmo quando ocorrem aparentes descontinuidades nesses processos haverá retomadas em que a evolução será pressuposto da revolução desse desenvolvimento, e vice-versa.

38 As questões envolvidas neste Novo Método são abordadas no capítulo destinado a análise dos dados obtidos através da atividade de campo. 
Uma proposição essencial de Vygotsky refere-se justamente à interação entre aprendizado $^{39}$ e desenvolvimento (1991). Vejamos, então, as implicações desta concepção para a Educação.

\section{A relevância dos processos de interação entre o aprendizado e o desenvolvimento}

Para discutir as relações entre aprendizado e desenvolvimento, Vygotsky contrapôs-se a três grandes posições teóricas que também pretenderam explicar essas relações. É muito relevante o processo metodológico que levou Vygotsky a refutar as três correntes. É necessário reconhecer que essas concepções marcaram muito o entendimento do que seja aprender, mas também as formas de se ensinar decorrentes da forma de entender a aprendizagem.

Vygotsky resumiu essas concepções indicando que a primeira dessas teorias, o que inclui a pesquisa de Piaget, defende que "o aprendizado forma uma superestrutura sobre o desenvolvimento, deixando este último essencialmente inalterado" (1991: 84). Em segundo lugar, estariam as teorias que acreditam ser os dois "processos coincidentes em todos os pontos, como se duas figuras geométricas idênticas coincidem quando superpostas" (1991: 85).

Por fim, a terceira corrente teórica defende que há uma relação entre os dois processos e poderia ser representada "por dois círculos concêntricos, o menor simbolizando o processo de aprendizado e o maior, o processo de desenvolvimento evocado pelo aprendizado" (1991: 85). Assim, ao dar um passo no aprendizado, a criança dá dois no desenvolvimento, não havendo coincidência entre os dois processos.

Vygotsky não considera tais concepções suficientes para explicar a relação entre aprendizado e desenvolvimento. Ao analisar e criticar essas posições,, formula uma alternativa teórica que vai levar a uma visão tanto mais

39 Aprendizado: segundo Oliveira (1995), a adoção do termo aprendizado, na tradução portuguesa, equivale à palavra obuchenie, que em russo garante a expressão "processo de ensino-aprendizagem" procurando revelar a articulação das ações de ensino impactando a aprendizagem, num contexto que implica o reconhecimento das relações sociais. 
esclarecedora sobre a interação entre aprendizado e desenvolvimento quanto coerente para os desdobramentos que faz decorrer para o ensino.

Assim, compreender a esfera da realidade através da análise psicológica permite compreender as relações internas dos processos intelectuais despertados pelo aprendizado escolar, abre a possibilidade de a ação educativa favorecer a formação da criança nos múltiplos aspectos que esta pode alcançar.

Também desvela para o professor "como os processos de desenvolvimento estimulados pelo aprendizado escolar são essenciais para revelar a rede interna e subterrânea de desenvolvimento de escolares" (VYGOTSKY, 1991: 85).

Ao refutar as hipóteses das três concepções que analisa, acaba por construir a hipótese de que o aprendizado, embora esteja diretamente relacionado ao desenvolvimento, jamais se realiza em igual medida ou de forma paralela. Conclui, ainda, que "A revelação dessa rede interna e subterrânea de desenvolvimento de escolares é uma tarefa de importância primordial para a análise psicológica e educacional" (VYGOTSKY, 1991: 91).

Acrescenta também que os processos de desenvolvimento e aprendizado escolar se estabelecem por relações dinâmicas altamente complexas que não podem ser compreendidas a partir de uma concepção imutável. Argumenta que "cada assunto tratado na escola tem a sua própria relação com o curso do desenvolvimento da criança" (VYGOTSKY, 1991: 91).

Finalmente, aponta a necessidade de se reexaminar o problema da disciplina formal, que compõe a organização curricular da escola, buscando "compreender a importância de cada assunto em particular do ponto de vista do desenvolvimento mental global" (VYGOTSKY, 1991: 92).

Para isso, propõe o conceito de zona de desenvolvimento proximal, que

[...] é a distância entre o nível de desenvolvimento real, que se costuma determinar através da solução independente de problemas, e o nível de 
desenvolvimento potencial, determinado através da solução de problemas sob a orientação de um adulto ou em colaboração com companheiros mais maduros (VYGOTSKY: 1991:97).

\section{A zona de desenvolvimento proximal}

Em sua pesquisa sobre a questão do aprendizado, Vygotsky partiu da discussão de que este acontece antes que a criança entre na escola. Desde "que passa a assimilar os nomes de objetos em seu ambiente, ela está aprendendo" (1991: 94). Portanto, a criança vai atingir um primeiro "nível de desenvolvimento real quando se estabelecerem as funções mentais como resultados de certos ciclos de desenvolvimento já completados" (1991: 95).

Vygotsky $(1995,96)$ vai demonstrar que, entretanto, "existem funções que ainda não amadureceram, mas que estão em processos de maturação em estado embrionário", o que vai caracterizar uma zona de desenvolvimento proximal prospectiva, apontada para ciclos e processos em formação ${ }^{40}$.

A zona de desenvolvimento proximal, a partir dos processos de aprendizado, transforma-se em nível de desenvolvimento real, posteriormente. O papel fundamental do educador é, justamente, reconhecer a necessidade de criar e atuar nessa zona do desenvolvimento proximal, de forma consciente, intencionalmente, sistematicamente. Para isso deve criar tais zonas no âmbito das relações que se estabelecem no processo ensino aprendizagem. A mediação escolar deve ter por princípio esse trabalho pedagógico, que não dependerá dos aspectos cognitivos de cada criança, mas das práticas culturais, dentre as quais as escolares, que permitem decidir o que ensinar. Em nossa realidade socioeconômica e política, em que as crianças pequenas chegam ao

40 Ressalvo que as citações desse parágrafo são literais da obra "Formação Social da Mente". Há, dentre os vigotskyanos, os que evitam as traduções para o português por não corresponderem, segundo dizem, ao que o pesquisador teria de fato pretendido afirmar. Exemplo: maturação é um conceito mais afim com o campo das teorias cognitivistas e corresponderia à concepção de aprendizagem decorrente de estágios de desenvolvimento para os quais os órgãos estariam preparados. Sem pretender entrar nessa polêmica, o fato é que a tradução da obra que utilizei mantém o termo há muitas edições e decidi mantê-lo também. 
sistema de ensino cada vez mais cedo, o professor é um provedor de direitos à criança, no sentido da possibilidade que possui de pensar e refletir sobre a ação educativa que Ihes será oferecida.

Citando a pesquisa de Dorothea MacCarthy, Vygotsky indica que "há funções que as crianças só podem por em ação sob orientação, em grupos, e em colaboração umas com as outras, porque não as dominaram de forma independente" (1991: 100).

Para a Educação, este aspecto é decisivo. O aprendizado, a partir do conceito de ZDP, "desperta vários processos internos de desenvolvimento, que são capazes de operar somente quando a criança interage com pessoas em seu ambiente e quando em cooperação com seus companheiros" (VYGOTSKY, 1991: 101).

O conceito vai permitir, ainda, a afirmação de que o "bom aprendizado é somente aquele que se adianta ao desenvolvimento" (VYGOTSKY, 1991: 101).
Assim, o aprendizado é um aspecto necessário e universal do processo de desenvolvimento das funções psicológicas culturalmente organizadas e especificamente humanas. (1991: 101)

É importante ressaltar que Vygotsky propõe a unidade, mas não a identidade entre os processos de aprendizado e os processos de desenvolvimento interno. Segundo ele, esta forma de compreender altera a visão tradicional de que uma vez dominada uma operação, no âmbito da aprendizagem, as crianças se desenvolveram. Ao contrário, aí é que esses processos se iniciam.

Por fim, gostaria de pensar, brevemente, sobre a linguagem, que desempenha papel essencial nos processos de mediação simbólica e na internalização das funções psicológicas superiores, também mediadora no processo de desenvolvimento, por constituir-se como sistema simbólico básico na experiência humana, no aprendizado e no desenvolvimento das pessoas, em qualquer grupo social. 
A linguagem se estabelece, a princípio, enquanto comunicação. Os signos da linguagem devem ser suficientes para expressar e garantir que se comunique idéias, sentimentos, vontades, pensamentos. Para isso o homem cria palavras com significados que traduzam de forma compreensível para os outros o que deseja comunicar e expressar.

Desta forma a linguagem vai organizando a realidade através de categorias conceituais. Ao organizar a realidade a partir de conceitos faz surgir um pensamento generalizante (OLIVEIRA, 1995: 43) a partir do que ficam estabelecidas as relações entre pensamento e linguagem.

Pensamento e linguagem, entretanto, não são processos articulados, mas articuláveis. Uma inteligência pragmática, segundo experimentos com primatas estudados por Vygotsky, revela que estes podem usar instrumentos para atuar e solucionar problemas. Ainda que emitam sons e se expressem através de gestos, entretanto, não estão articulando pensamento e linguagem.

O processo de trabalho, que caracteriza a condição humana, levou ao uso de instrumentos destinados a transformação da natureza. Para esse uso ocorreu o processo comunicativo, que permitiu as ações colaborativas de planejamento o que acabou originando o surgimento de significados compartilhados, no bojo dos sistemas comunicativos que foram se construindo. É assim que se constrói o pensamento verbal que recorre a um sistema de signos chamado linguagem. Foi nesse momento histórico do desenvolvimento da espécie humana que se verificou a transformação dos aspectos biológicos em sócio-histórico.

A criança pequena já utiliza instrumentos para relacionar-se, prevalecendo-se de uma inteligência prática, que caracterizaria uma fase pré-linguistica. Em termos comunicativos já ocorre, também, a manifestação de risos, gestos, balbucios que favorecem o alívio emocional.

Ao participar do contexto social articula-se pensamento e linguagem. Em virtude da mediação proporcionada por parceiros que já dominam de forma 
estruturada a linguagem, vai emergir o pensamento verbal que ao longo do processo de desenvolvimento resultará na linguagem racional.

Os estudos desses processos comunicativos, tipicamente humanos, que envolvem os processos psicológicos superiores, foram os responsáveis pela possibilidade de se compreender a condição sócio-histórica do homem.

Os processos comunicativos estão baseados nas palavras. Estas trazem em si o significado, que para Vygotsky estabelece duas funções básicas, que já mencionamos anteriormente: como possibilidade de intercâmbio social e como condição do pensamento generalizante.

Os diversos significados que a palavra pode assumir - e aqui o significado é considerado como fenômeno do pensamento conforme proposição dos estudos de Vygotsky - serão continuamente transformados durante o desenvolvimento do sujeito.

No processo de escolarização essas transformações tornam-se peculiares já que ocorre uma intervenção intencional, por parte do educador, destinada à formação conceitual das crianças. Esse processo de aprendizagem escolar implica em que

As transformações de significado ocorrem não mais apenas a partir da experiência vivida, mas, principalmente, a partir de definições, referências e ordenações de diferentes sistemas conceituais, mediadas pelo conhecimento já consolidado na cultura (OLIVEIRA, 1995: 50).

Esse processo mais complexo de uso da palavra, seus significados e sentidos diversos, resultam na possibilidade de a linguagem desempenhar a função generalizante do pensamento além de permitir os processos de abstração. Estas características da linguagem remetem à necessidade de se distinguir entre a fala externa e o discurso interior que se desenvolve no sujeito, como recurso para organizar raciocínios, referências e decisões internas. 
É nesse contexto caracterizado por atividades sociais de uso da fala (interpsíquica) e a atividade individualizada através do discurso interno (intrapsíquico) que atua o educador, no âmbito da formação escolar.

Para este estudo a consideração da relevância dos processos de mediação e de como ele se constitui, conforme vimos até aqui, será a base de análise do estudo de caso. Não vou aprofundar a discussão sobre a formação de conceitos, porque a finalidade era observar as contribuições das representações gráficas, enquanto instrumentos técnicos e simbólicos, na organização dos processos educativos da Educação Infantil destacando as atividades que ativam as funções psicológicas superiores e as relações sociais que recorrem ao uso da linguagem.

Não pretendi ir além, observando como tais experiências pedagógicas resultariam em formação de conceitos. No processo do aprendizado e do desenvolvimento haverá esse momento em que a criança construirá os conceitos. Mas neste estudo preocupo-me com a possibilidade de compreender e organizar as atividades que são oferecidas às crianças que ainda vivenciam experiências relevantes no âmbito do desenvolvimento de conteúdos culturais.

Hoje a inserção das crianças no sistema de ensino formal pode se dar desde 0 anos de idade. Essa formalização da educação em idade to precoce deve ser objeto de atenção dos educadores. O que se ensina nessa etapa é decisivo para a formação da criança.

Vygotsky discute a questão da formação dos conceitos considerando a idade escolar. Ao longo deste trabalho tenho considerado que a discussão sobre idade escolar, num contexto histórico em que as crianças chegam cada vez mais cedo ao sistema de ensino, mereceria mais e aprofundados estudos acerca do tipo de mediação escolar que se deve estabelecer com crianças pequenas.

Esta é uma discussão fundamental, na medida em que a ausência de estudos dessa natureza impede que se compreenda precisamente como e quais são as condições para o desenvolvimento de uma didática da Educação Infantil, que 
acaba por recorrer aos procedimentos didáticos destinados as séries iniciais. Isto tem ocasionado a discussão relativa aos fenômenos de antecipação da escolarização destinada à chamada idade escolar.

No próximo item discuto, dentro de certos limites e possibilidades, justamente os impactos destas teorias para o ensino, fazendo um esforço de compreensão de como isto pode alcançar a Educação Infantil.

\section{Impactos das teorias sócio-históricas no ensino}

Quando se fala em visão tradicional de ensino, chega-se ao campo dos valores e do debate sobre a função social da escola e da natureza política envolvida no processo educativo formal. Não se pode ignorar, e não o fiz ao longo deste trabalho, que a teoria sócio-histórica proposta por Vygotsky e seus colaboradores foi o fruto do trabalho científico orientado pelos princípios da revolução socialista.

No Capítulo I discuti as questões relativas ao contexto político para inserir a discussão sobre a Educação enquanto direito ao aprendizado que lhe permitisse inserir-se nas relações e práticas sociais numa perspectiva emancipatória - que adoto como conceito que se contrapõe a concepção liberal de direito à educação para todos - na medida em que não se pode esperar que políticas públicas que não se efetivam possam garantir educação de qualidade para todos.

É necessário que o processo educativo possa ir além, então, dos aspectos formais e garanta ao sujeito histórico da educação as condições para atuar no mundo, na dimensão da cidadania, o que está mais relacionado ao âmbito dos princípios educativos postos em prática por equipes pedagógicas na esfera escolar e institucional e articulados as finalidades da educação expressas pelo processo participativo envolvendo escola, família e comunidade.

Assim, é importante reconhecer que a teoria sócio-histórica se explica a partir da emergência do ato político revolucionário. E isto representa muito para a 
compreensão de suas proposições. Faço esta ressalva ao introduzir a discussão necessária para a compreensão do processo educativo enquanto dimensão essencial à formação social e individual.

Quando falo do processo educativo, refiro-me a pessoas e coletivos organizados para cumprir um objetivo decisivo para as relações sociais e para o desenvolvimento mental do individuo. $O$ coletivo da escola é que permite a construção dos modos de ser de todos os membros de sua comunidade. A tomada de consciência do que ainda não se sabe impulsiona o reconhecimento dos limites do que se sabe e faz avançar a busca por novas possibilidades. Isto é verdadeiro para todos os envolvidos no processo.

A essência desse processo é o que constitui uma zona de desenvolvimento proximal. O papel da comunicação, neste sentido, é fundamental. E este se dá, pensando o processo educativo e o aprendizado, de forma privilegiada, na escola. Também remete à discussão, já apresentada, sobre aprendizado e desenvolvimento.

Há, entretanto, um terceiro aspecto que se deve considerar quando a reflexão ocorre sobre as questões do ensino. Ensino é elemento constituinte da esfera escolar. No caso da teoria que adotamos como parâmetro, Cechini (1991) lembra que a teoria sócio-histórica propõe que a escola seja um espaço de superação da divisão do trabalho.

Esse princípio, articulado aos outros dois, comunicação e aprendizado/ desenvolvimento, é que dá os fundamentos para uma pedagogia sóciohistórica que explica o processo educativo; que não separa a formação técnicocientífica de formação humanístico-literária. Do ponto de vista deste trabalho, esse aspecto é absolutamente relevante.

É importante lembrar que a atividade de campo que desenvolvi, ocorreu em Diadema, cidade do ABC paulista, cujas administrações, desde 1982, pertencem ao campo democrático popular. Essas gestões influenciaram 
profundamente a concepção de educação que permeia o sistema de ensino municipal, como veremos no próximo capítulo.

Com relação à questão da superação da divisão do trabalho na escola lembro que isto vem em contraposição às experiências dos países capitalistas que o faziam em razão da necessidade de articular formação e produtividade subordinando a esta o processo formativo. Esse modelo definiu a escola no ocidente consolidando aí a idéia de formação vinculada à ideologia da produtividade - consumo - competitividade, transformando-a em valores de fundo na escola.

Mas a escola, onde se realiza a educação formal, tem a "finalidade de alcançar objetivos imediatos e definitivos quando coloca em ação as capacidades potenciais do aluno, e, em conformidade, dirige a sua utilização" (KOSTIUK, 1991: 32). E é o ensino, que não deve se confundir com a Educação em si, o elemento que vai garantir os diferentes aspectos que interagem no processo educativo - intelectual, moral, estéticos, práticos, físicos, éticos -, "se asseguradas a participação da criança nas diversas atividades necessárias para um desenvolvimento das suas potencialidades em todas as direções" (KOSTIUK, 1991: 32).

A questão do protagonismo da criança no processo educativo constitui um princípio essencial para que se rompa a força dos valores referentes à produtividade - consumo - competitividade que marcam as experiências escolares.

$\mathrm{Na}$ Educação Infantil, se revela uma antecipação do processo de escolarização típico das séries iniciais. As crianças são iniciadas nos processos de copiar, escrever e ler cada vez mais precocemente. As famílias acabam valorizando esses aprendizados escolarizados e tendem a não reconhecer a pertinência dos aprendizados que envolvem os aspectos sociais, humanos, lúdicos, simbólicos e pessoais como relevantes para as crianças pequenas. 
O que acaba ocorrendo nessa matriz conceitual que tem desdobramentos nas formas de organização e nas práticas pedagógicas das instituições de educação infantil é o que nos aponta Kostiuk, quando afirma que

A educação que separa as palavras dos atos é um fracasso; a instrução pedagógica verbal, que a criança não põe em prática, não traz nenhuma mudança real à sua vida, a sua posição no coletivo. A educação fracassa se não toma em consideração as diversas interconexões da criança com o ambiente, se está alienada da sua vida real, das condições subjetivas (apenas através das quais pode atuar), da precedente história do desenvolvimento de cada aluno, da sua idade e das suas características individuais, das suas capacidades, interesses, exigências e outras atitudes perante a realidade. Se a educação considera a criança "apenas como um objeto e não como um ser vivo" (Makarenko), ignora a sua atividade autônoma e mina a sua independência, não efetua o que se propõe (apesar das muitas e importantes "medidas" educativas exteriores), de modo que o trabalho resulta, na realidade, absolutamente estéril (KOSTIUK, 1991: 33).

O trabalho de campo realizado permitiu uma aproximação com esse eixo reflexivo - o que de fato significa educar. Embora o aprofundamento deste aspecto ocorra no próximo capítulo quero destacar que é possível verificar a distinção dos processos educativos orientados por uma ou outra concepção das que vimos debatendo. O caso concreto analisado indica que, sobretudo entre a população da cidade de Diadema que faz a experiência de acesso a uma Educação Infantil comprometida com o desenvolvimento da criança e de rompimento com ações de custódia assistencial, há ali um processo educativo destinado a propor às crianças novas tarefas, provocar-Ihes novas perguntas, 
procurar meios necessários para desempenhar essas ações conduzindo de forma sistemática o desenvolvimento através das ações educativas.

Quero então destacar que, diante desse contexto em que se dá o processo educativo - que inclui o ensino e suas ações educativas, pedagógicas, mediadas -,trabalhar com as representações gráficas significa aproximar as crianças da oportunidade de construir conhecimentos sobre sua espacialidade, a partir de seu lugar de vivências, e da investigação das paisagens, dos espaços vividos.

Os recursos da escola, e isto inclui as condições de organização dos espaços e ambientes, deve garantir acesso a materiais visuais e verbais para que a experiência da criança se organize através de atividades práticas, simbólicas, que Ihes permita produzir análise e síntese.

Mechinskaya (apud VYGOTSKY, 1991), refere-se à importância do material escolar que envolve o estudo da natureza e, por outro lado, vimos que o RCNEI toma o cuidado de propor as condições para que as crianças construam seu conhecimento de mundo articulando Natureza e Sociedade. Para este autor soviético, "os fatos e fenômenos da natureza favorecem a organização do ensino de modo que se baseie na percepção direta dos alunos e na sua experiência prática" (MENCHISKAYA; apud VYGOTSKY, 1991: 37), lembrando que os componentes visuais são essenciais ao conhecimento e às características do pensamento da criança.

Nas Ciências Naturais, o material visual inicial é suficiente para a análise e generalização. Nas ciências humanas, todavia, o material disponível deve ser construído através da imaginação, o que vai exigir procedimentos metodológicos complexos que envolverão descrever com clareza, usar imagens, fotografias etc.

A nós interessa refletir, então, sobre as contribuições da Geografia na definição de referências para que se construa metodologicamente as condições do ensino na Educação Infantil. Nessa etapa, os materiais construídos 
corretamente, bem como os procedimentos metodológicos e didáticos coerentes com os objetivos educativos, não podem prescindir da fundamentação científica.

Esse conjunto didático ${ }^{41}$ organiza as atividades significativas que contribuem para o desenvolvimento a partir do aprendizado que ocorre no processo de ensino-aprendizagem pertinente. Lembro que já discutimos anteriormente a distinção entre conhecimento científico de determinada Ciência e o conhecimento escolar, recurso cultural construído para garantir o processo civilizatório, ao qual se deve ter acesso através da instituição escolar, cuja função social é justamente a formação de uma cidadania ativa, que valorize os conteúdos culturais, apropriando-se criticamente desse acervo, capaz de tornar o homem um sujeito histórico autônomo ${ }^{42}$.

Para se trabalhar a representação gráfica é importante identificar sua pertinência como: 1 - material escolar adequado, 2 - instrumento de mediação capaz de favorecer o processo pedagógico, na medida em que é portador dos conteúdos, relações e práticas sociais através de signos próprios da linguagem que utiliza, 3 - enquanto conteúdo e conhecimento escolar apropriado ao processo formativo.

Menchiskaya faz importante distinção entre os processos que envolvem a percepção direta e aqueles mediados por linguagens específicas:

Na geografia física, tal como nas ciências naturais, o fundamento de grande número de conceitos

${ }^{41}$ Conjunto didático: material construído, procedimentos didáticos e metodologias envolvidos no processo de ensino-aprendizagem, coerentes com os objetivos educacionais.

42 O discurso sobre a emancipação decorre da atividade filosófica e científica intensas na passagem do século XIX para o XX, quando a idéia de progresso impulsionava essa visão libertária de homem, capaz de pensar o sujeito histórico, do direito, psíquico e moral. O sujeito histórico emerge da natureza política intervindo e decidindo sobre os destinos da vida em sociedade; o sujeito do direito constrói primeiro o direito a ter direitos (a superação da idéia de escravidão como possibilidade para a condição humana). A emersão desse sujeito histórico, entretanto, não eliminou a permanência da sujeição em contradição com a almejada autonomia e liberdade. Daí minha insistência em defender a emancipação do sujeito educativo para que possa usufruir do repertório que permite ao tirano de toda origem e ordem anunciar a inutilidade do conhecimento e dos saberes para dar hegemonia a pragmática tecnológica. Ainda que seja para construir a crítica, o direito de acesso a esse legado não superado historicamente, é essencial. 
encontra-se nos dados da percepção direta (rios e lagos, montanhas e planícies, bosques e desertos etc.). Mas a leitura de um mapa geográfico é um processo psicológico diferente. Também aqui a percepção direta proporciona os dados principais; mas o que os alunos vêem no mapa é um conhecimento condicionado pela realidade exterior, ou seja, símbolos visuais especiais. Se estes têm de proporcionar uma base sensorial ao pensamento, devem estar ligados à realidade, e isso exige uma preparação especial (MENCHISKAYA; apud VYGOTSKY, 1991: 55).

Creio que chego ao ponto central dos argumentos que apresento, para dizer que, por hipótese, o mapa e, no caso deste estudo, a representação gráfica (croqui de localização) mobiliza aspectos diferenciados do desenvolvimento da criança. Como diz o autor, os conceitos da Geografia Física constituem observáveis diretos. É possível usar o bosque da escola, o jardim, o pátio de terra em atividades que introduzirão na roda de conversa uma aproximação com esses elementos próprios de um ou outro espaço da escola, que nessa medida, transforma-se em experiência didática.

O mapa ou a representação gráfica, entretanto, permitirão uma observação de outra natureza, mediada por símbolos visuais especiais que estão reduzindo a realidade, o que implica reconhecer a intervenção de conhecimentos diversos, culturalmente construídos, que resultam numa representação dessa realidade, mas que não é a própria realidade representada.

O próprio autor aponta que isto desencadeia um processo psicológico diferente ao mobilizar e exigir uma preparação especial. O trabalho de campo que desenvolvi procurou organizar-se com base nessa necessidade de compreensão das condições para desenvolver uma atividade intencionalmente sistematizada partindo de uma observação direta da representação gráfica do lugar de permanência diário, interpretando os símbolos ali inseridos e as 
interações que estabeleceriam, a partir dessa interpretação: a-) com esse ambiente tão conhecido e agora ali representado; b-) com os elementos pictóricos representados - e quais se destacariam para cada uma delas a partir de sua atenção e memória -; e c-) com a necessidade de utilizar o croqui para se localizar - e que processos a atividade viria a desencadear quando se sugerisse às crianças que, utilizando a representação gráfica, encontrassem uma deliciosa surpresa.

A idéia era pensar a representação gráfica como esse modo especial de desencadear os processos diferenciados na observação do mapa, apontado por Menshiskaya, e verificar se as formas de representação gráfica presentes nos croquis de localização viriam a se constituir em material escolar, organizado, produzido e planejado pela escola, no âmbito do ensino, para proporcionar experiências de formação à criança, no que diz respeito ao conhecimento do lugar em que vive, de tal forma a não distorcer a realidade, através do desenvolvimento do raciocínio geográfico.

É fundamental que o lugar e suas paisagens seja de fato uma dimensão de formação da espacialidade da criança, que resulte no desenvolvimento do raciocínio geográfico e que um dos instrumentos dessa formação seja o croqui de localização que represente o seu lugar. É comum a produção de materiais

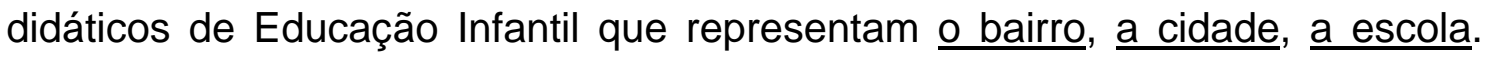
Porém esses lugares são concebidos através de uma prática didática que generaliza aspectos mais ou menos comuns aos bairros, cidades, escolas, a partir de um referencial idealizado.

Como visto, a criança tem direito a um material escolar capaz de the garantir as condições de desenvolver as experiências formativas referentes ao seu bairro, sua cidade, sua escola. No próximo capítulo, apresento a atividade de campo e, então, poderemos aprofundar a análise para a qual estas referências foram escritas. Mas adianto que a produção de material de representação gráfica a partir da própria escola constitui procedimento que introduz conteúdos significativos no trabalho de construção de identidade das crianças. No caso de 
Diadema, isto tem sido verdadeiro, inclusive, para o desenvolvimento da cidade, a partir das perspectivas da gestão democrática, como veremos.

No processo de construção deste estudo, procurei aprofundar minha busca das questões que envolvem o aprendizado e o desenvolvimento das crianças, a partir das teorias sócio-históricas. Segundo minha compreensão das proposições dessas teorias, o aprendizado e o desenvolvimento se articulam a partir da mediação que se estabelece entre as crianças e seus parceiros mais maduros, no âmbito das relações sociais, construindo-se então as possibilidades do conhecer, o que implica pensar a educação formal.

Para finalizar e concluir quero refletir sobre um aspecto que destaco das questões referentes a mediação. O quanto o ambiente institucional, organizado para a Educação Infantil, desempenha, ele próprio, a função mediadora. Um cuidado que se toma, neste caso, é identificar as especificidades envolvidas na organização e gestão das instituições destinadas à Educação Infantil.

Para Oliveira (2002), é importante recorrer às pesquisas internacionais para identificar os aspectos relevantes da educação nas creches e pré-escolas, numa etapa do desenvolvimento infantil para a qual se deve definir aqueles que efetivamente o favorecem. Na Europa, Estados Unidos, Japão, Coréia, Nova Zelândia etc., esses estudos chegam a pontos convergentes que revelam

[...] que o fato de a criança freqüentar uma instituição de Educação Infantil amplia suas condições de desenvolvimento cognitivo, físico, afetivo e da socialização... As crianças pequenas que se beneficiam de um serviço de qualidade tendem a desenvolver mais o raciocínio e a capacidade de solução de problemas, a ser mais cooperativas e atentas aos outros e a adquirir maior confiança em si (OLIVEIRA, 2000: 85). 
Considero a questão institucional a partir da finalidade de oferecimento de um serviço educacional de qualidade, fator decisivo de desenvolvimento, que permite a criança participar de um ambiente com o qual se familiarize e que lhe dê estabilidade e atenção.

Por outro lado, o estabelecimento de vínculos entre a criança, seus colegas, professores e objetos de conhecimento estabelece as condições definitivas para que seu aprendizado ocorra. Segundo Oliveira (2002), são esses vínculos o foco principal da ação educativa, organizada a partir dos processos de mediação.

A mediação escolar poderá garantir à criança experiências decisivas em termos desse aprendizado e desenvolvimento. A organização dos espaços da instituição de Educação Infantil e os arranjos curriculares como fator decisivo de uma prática pedagógica apropriada a essa etapa da educação. Não se pode ignorar os níveis de formalidade na Educação Infantil, já que ela compõe a Educação Básica, no âmbito do sistema de ensino. Isto significa admitir o grau de sistematicidade das ações pedagógicas que aí se constroem sem se recorrer a simples transposição das ações pedagógicas das séries iniciais.

Como essas ações se organizam e o quanto são relevantes para as experiências das crianças deve ser o foco de atenção dos que pretendem pensar as questões da Educação enquanto dimensão da construção social da criança ${ }^{43}$.

Considerando essa construção social, defendo que o debate em torno do binômio educar-cuidar como possibilidade de superação do antagonismo que se vislumbrou entre ambos, também é um avanço. Na proposta pedagógica das instituições de Educação Infantil, ou daquelas sob a responsabilidade da Assistência Social, o educar era próprio da professora/pedagoga e o cuidar das atendentes ou auxiliares. Vimos que este quadro mudou.

${ }^{43}$ Construção social da criança: Ao mesmo tempo em que a criança modifica seu meio, é modificada por ele. Em outras palavras, ao constituir seu meio, atribuindo-lhe, a cada momento, determinado significado, a criança é por ele constituída; adota formas culturais de ação que transformam sua maneira de expressar-se, pensar, agir e sentir (OLIVEIRA, 2002: 126). 
Também estão redimensionadas as condições do trabalho educacional sob a diretriz das ordens religiosas assim como os cuidados higienistas influenciados por necessidades de práticas sanitárias que acabaram identificando a Educação Infantil, na esfera do Estado, como serviço destinado a população carente. Até mesmo o discurso científico decorrente das concepções psicanalíticas que alcançaram a Educação Infantil passam pelo crivo do debate educacional, que traz, por outro lado a dimensão cultural como necessária ao aprofundamento dos temas relacionados a Educação de modo geral.

A Educação formal da criança pequena, desde a creche, obriga a reflexão sobre a importância dos valores sociais nas experiências cotidianas que as envolve no âmbito da instituição. A organização dos espaços e os arranjos curriculares são dimensões adequadas para se articular as atividades destinadas a inserção dos valores no processo de realização da aprendizagem e do desenvolvimento. Para Oliveira (2002),

Valores sociais, preocupações pragmáticas, intuições extraídas da experiência cotidiana são elementos que colaboram para delinear os objetivos, atividades e estratégias de ensino adequados aos níveis de desenvolvimento das crianças atendidas e às exigências sociais que se apresentam para elas. (OLIVEIRA, 2001: 169).

É sobretudo neste aspecto que considero a importância de se tomar noções e conceitos do campo da Geografia para, como se deve fazer com o conhecimento científico de modo geral, debater as possibilidades de se realizar as transposições didáticas apropriadas ao trabalho educativo com as crianças pequenas. Este é o ponto em que compreendo a importância desta pesquisa que olha para as possibilidades pedagógicas das representações gráficas dos lugares de vivência, das crianças.

As atividades que se organizam nas instituições de ensino da Educação Infantil constituem experiência capaz de mobilizar as capacidades das crianças 
favorecendo a construção de competências essenciais para as práticas sociais globais de que nos falava Saviani (1999).

A organização dos ambientes e espaços da Instituição de Ensino está entre as ações educativas essenciais ao trabalho docente. As situações organizadas nos ambientes é que podem transformá-los em educativos. O ambiente educativo é preparado para, de forma protegida, garantir à criança acesso a situações que o sujeito em formação deverá enfrentar. De acordo com Oliveira (2001: 1995), "o ambiente define diversas práticas sociais que desenvolvem diferentes competências, devendo haver grande preocupação com a funcionalidade e a estética dos ambientes, já que todos os espaços servem para a educação visual, expressiva, cognitiva, ética".

A organização de espaços destinados a atividades diversificadas - cantinhos para as profissões dos pais, para a casa, para o descanso - vai criar as condições para que o educador possa sair do foco de atenção das crianças. Enquanto os pequenos grupos interagem num ambiente instigante em atividades simbólicas, o educador, ao alcance da vista das crianças, pode atender a outros grupos de forma mais individualizada.

Os espaços assim organizados podem apoiar o desenvolvimento da memória, da imaginação, da locomoção e da fala. Assim, o educador pode criar um ambiente em condições de opor resistência à complexidade da "vida lá fora", para a qual as crianças se dirigem, mas para a qual não estão preparadas.

É necessário que o mediador/educador possa construir as dimensões acima, pensando e agindo no sentido da intervenção representada pela atividade pedagógica. Enquanto educadora e recorrendo ao estatuto da prática, que considero instância essencial da práxis, afirmo que a qualidade da mediação pode garantir direito de acesso à Educação como, também, pode abrir desvios de caminho tornando a escola um ambiente inóspito, se a condição de autonomia da criança for desrespeitada. 
Penso que tomar consciência desses riscos, implicados na ação educativa, leva o educador a compreender, também, que o sujeito da educação excede sua própria natureza, não está determinado por ela. Traz aspectos que estão dados naturalmente, mas constrói outras dimensões que o tornam sujeito.

O desenvolvimento do sujeito está atrelado ao cuidado de outrem. A mediação de outrem. Não há o momento em que o homem esteja pronto e sua educação finalizada ${ }^{44}$. Portanto, vale a pena educar a partir desse feixe de valores que respeita a natureza histórica e sua qualidade intrínseca de inacabamento. Não haverá um momento final do processo educativo para o qual dirigir ou guiar as crianças.

O processo educativo indica a possibilidade da superação como marca do desenvolvimento e, para isso, o professor precisa atuar como mediador. Essa mediação se refere ao processo ensino-aprendizagem. Por outro lado, também colabora para o questionamento, convidando o sujeito "a se descentrar de si mesmo para se reencontrar acima de si mesmo" (HADJI, 2001: 138).

44 A educação tem por fim último fazer compreender essa exigência de superação. Seu papel é auxiliar o homem a perceber e a aceitar sua verdadeira natureza que é a de um ser que sente a exigência do aperfeiçoamento (HADJI, 2001: 100). 


\section{CAPÍTULO IV - CROQUIS DE LOCALIZAÇÃO E EDUCAÇÃO INFANTIL: O ESTUDO DE CASO}

\section{A interpretação dos croquis de localização: uma possibilidade didática?}

Considerando a finalidade do estudo, que buscou observar a interpretação que as crianças fizeram de croquis de localização oferecidos em atividade desenvolvida na escola, decidi partir das questões envolvidas na mediação como ponto central desta análise. Para cumprir essa finalidade tomei como referência às teorias sócio-históricas.

O acolhimento da criança na instituição de Educação Infantil implica a organização de um ambiente capaz de oferecer as condições ambientais propícias ao aprendizado e desenvolvimento. O planejamento pedagógico desses arranjos consiste uma das pilastras dos procedimentos didáticos da Educação Formal, que se constrói na escola.

Os arranjos espaciais nas instituições vão influenciar as possibilidades e aprendizado e, conseqüentemente, o desenvolvimento cognitivo, afetivo, físico e o próprio processo de socialização da criança. A mediação que os arranjos espaciais estabelecem - o que inclui as relações criança-professor, criançacriança, com os instrumentos e símbolos disponíveis no ambiente - possibilita o desenvolvimento das crianças para resolver situações-problema, usando o raciocínio de forma atenta e cooperativa.

Portanto tratar das questões ambientais da instituição e das espacialidades aí implicadas representa abrir perspectivas para a organização de atividades com as crianças, que dependem dessa interação para aprender e desenvolver-se. 


\section{Definindo os croquis de localização}

No capítulo anterior apresentei a concepção teórica que tomo para incluir a análise geográfica como decorrência da sistematização, ordenamento e espacialização da informação geográfica, na esfera escolar, através do processo ensino-aprendizado.

As representações gráficas, aqui consideradas através de croquis de localização, possibilitam a visualização dessas informações, contidas nas possibilidades de organização dos espaços geográficos e suas representações. Proponho que esta é uma possibilidade didática que delimita um campo de colaboração da Geografia para o Ensino na Educação Infantil. O uso dos mapas nesse nível de ensino, conforme já discutido, é possibilidade que se apresenta em vista das transformações que se observa no âmbito das organizações curriculares.

Já não se pode sustentar que somente no Ensino Fundamental se introduz os mapas como conceito/ conteúdo nas matrizes curriculares da área das Ciências Humanas, através da Geografia.

Por constituírem representação gráfica simplificada, que podem ser realizadas por não cartógrafos, os croquis compõem importante aspecto na produção de materiais e procedimentos didáticos, por fundamentar o raciocínio geográfico.

Neste trabalho demonstro que além de reconhecer as linguagens comunicativas envolvidas na leitura e interpretação de mapas, os croquis podem ser compreendidos como importantes instrumentos semióticos, em condições de compor as atividades planejadas com o objetivo de ativar as funções psicológicas superiores como a percepção, atenção e a memória, garantindo os processos de internalização dessas funções o que resulta na atuação e criação da zona de desenvolvimento proximal, sempre a partir da mediação docente. 
A leitura e interpretação dos mapas ativa a função da estrutura psicológica, responsável pela atenção, pelo uso do instrumento. A criança, diante do croqui de localização representando graficamente o seu lugar de vivências, é capaz de dominar sua atenção focando-a a partir de centros estruturais novos.

A criança envolvida na atividade de interpretação de croquis destaca "figuras novas", ampliando o seu controle sobre essas atividades a partir da atenção que mobiliza para "poder ver" a representação.

Ao ativar a atenção e a memória os croquis transformam-se em instrumentos de um novo modo de interpretação ao qual a criança vai recorrer, para unir elementos das experiências passada e presente.

A introdução de elementos como a legenda, nos croquis, torna possível observar que a criança vai da preocupação com o resultado da interpretação para o domínio da natureza da solução das situações propostas. Os croquis de localização são, portanto, excelentes instrumentos para a organização de atividades simbólicas. As atividades simbólicas têm por função organizar situações específicas em que o uso do instrumento produz formas fundamentalmente novas de comportamento.

Os croquis consistem um modo expedito de representar, registrar e demonstrar através de desenhos, um objeto, uma idéia de projeto ou uma visão do ambiente (DIAS, 2000). Croquis de localização apresentam a informação geográfica através da correlação e síntese que essa representação possibilita, de um determinado espaço. Mesmo sendo o resultado de uma representação rápida em que os parâmetros de qualidade das informações são relativas, nos croquis de localização construídos com a finalidade didático-pedagógica, os fenômenos devem permitir que correlações e interações dos vários elementos, estejam claros.

Os croquis de localização não chegam a ser definidos como mapas, já que não exigem o uso de técnicas em sua elaboração. Na Educação Infantil, podem ser propostos, como constructos, de novas possibilidades didáticas, que 
esclarecem questões, aspectos, relevâncias implicadas na compreensão da espacialidade do lugar de vivência da criança, o que pode resultar na construção do raciocínio geográfico.

É tarefa da equipe pedagógica da Escola a construção de um amplo repertório de croquis de localização, dos vários espaços internos e externos da Instituição de Ensino, de seu entorno, e quando necessário, de lugares virtuais, desde que relevantes e significativos para a experiência das crianças, trazidos por força das interações do coletivo, com as mídias e os recursos tecnológicos de comunicação, pela narrativa, relatos e intervenções das crianças.

O croqui permite a visualização de informações de espaços vividos pela criança, base para o desenvolvimento do raciocínio geográfico.

[...] o croqui em Geografia aparece vinculado à um tipo de trabalho que se constrói paulatinamente enquanto discurso gráfico, como uma ocasião de ensaios ou mesmo de síntese momentânea do estado de uma reflexão. Sempre fazendo referência a um certo tema e sem a preocupação de exaustividade da informação, o croqui se revela como uma primeira tentativa de compreender uma realidade em construção, de forma simples e arrojada. (DE BIAGGI; apud DIAS, 2000: 42).

A concepção de croqui aqui sintetizada é trazida de Simielli (1996):

- Croqui é uma representação esquemática dos fatos geográficos.

- Os croquis simplificam, mantém a localização da ocorrência dos fatos e evidenciam os detalhes significativos.

- Os croquis podem ser assim classificados: croquis de análise-localização (permitem a localização e análise de determinado fenômeno); Croqui de correlação (correlaciona duas, três ou mais ocorrências); Croqui de síntese (permite análise, correlação e síntese do espaço). 
Os croquis de análise-localização foram utilizados a partir da hipótese que uma vez tendo analisado e localizado pontos de referência, as crianças tomariam a iniciativa de localizar o elemento surpresa resolvendo a situação problema que Ihes seria proposta para resolver. A indicação das finalidades dos outros tipos de croquis, entretanto, já apontam para as possibilidades de aprofundamento do trabalho com os croquis em situações mais complexas, que sejam planejadas de forma coerente com a proposta educacional das instituições de ensino.

Os elementos essenciais que os croquis podem introduzir na Educação Infantil, tomando ainda como referência as proposições de Simielli (1996), são:

- Visão oblíqua e vertical

- Imagem bidimensional

- As representações propostas a partir da interação/mediação.

Ao introduzir as representações gráficas pode-se desenvolver o trabalho com elementos básicos das representações cartográficas

- Ponto

- Linha

- Área

Por fim a estruturação da legenda supõe a introdução de elementos para a observação, para o agrupamento e para a representação em si (SIMIELLI, 1996). Trabalhar com a legenda nos croquis de localização inclui o desenvolvimento de noções a partir da observação e identificação dos elementos da representação. Num segundo momento é possível hierarquizar, selecionar, generalizar e agrupar (agrupamento) esses elementos.

O terceiro momento envolvendo a representação especifica-se no caso deste estudo de caso. Como a investigação, envolveu um procedimento didático, que trabalhou a interpretação das crianças de um croqui de localização elaborado com a finalidade de introduzir as noções da representação gráfica, a criança ainda não participou do processo de construção da representação. 
É importante esclarecer que a criança poderá representar na Educação Infantil, trabalhando com mapas mentais, croquis de localização de sua autoria. Entretanto este estudo buscou refletir sobre a necessária produção de croquis de localização como instrumentos didáticos, de mediação e sua aplicação em situações de ensino. A preocupação, como já apontando anteriormente, é com a possibilidade didática e o uso na relação ensino-aprendizagem.

Portanto, neste caso, a legenda contribui para atividades que culminam com a comparação. No âmbito do estudo foram utilizados elementos bidimensionais para a construção da representação, de natureza pictórica (evocativos/ figurativos) na estruturação da legenda, o que serviu de parâmetro para as crianças solucionarem a situação problema. Neste caso a legenda não utilizou níveis de representação abstrata, embora isto possa ser proposto no aprofundamento do trabalho com os croquis de localização.

E importante, para a equipe pedagógica, encarregada de produzir os croquis de localização, relacionados aos eixos e temas do trabalho pedagógico, fazer escolhas e categorizar as informações que serão representadas. Este nível de aprofundamento do trabalho docente garantirá o planejamento das atividades que envolvam a construção dos croquis por parte das crianças, a partir de uma concepção que lhes garanta a experiência de se tornarem leitores das cartas e mapeadores conscientes.

A linguagem gráfica deve ser utilizada com cuidado, compondo a representação gráfica com a finalidade de enriquecer as atividades simbólicas, recorrendo ao uso de elementos pictóricos, cuja generalização recorre a maquete mais que aos mapas. A generalização (processo que permite a construção do croqui pela escolha de aspectos considerados essenciais a representação), neste caso, pode decorrer do trabalho com as maquetes que podem ser introduzidas como importante instrumento na organização de conteúdos para o eixo Natureza e Sociedade. 
Com o avanço das experiências de uso poderão ser introduzidos novos elementos simbólicos, da linguagem gráfica, na representação. Esses elementos são importantes para a construção da legenda.

Os títulos dos croquis podem constituir um primeiro momento de construção coletiva de sua interpretação após todo o processo de análise. Isto pode ser feito como atividade complementar ao trabalho de produção do croqui, por parte da equipe pedagógica. A legenda, o título e as informações contidas no croqui revelam o raciocínio implicado em sua elaboração e podem ser desenvolvidos como atividades dentro de uma unidade de ensino destinada a interpretação ${ }^{45}$.

Feita esta definição de croqui de localização, já é possível passar a apresentação e caracterização do campo, em que se desenvolveu a atividade. A seguir apresento a caracterização da escola em que aconteceu o estudo de caso. Para realizar uma adequada contextualização da escola apresento aspectos relevantes das Políticas Educacionais do Sistema Municipal de Ensino.

\section{O estudo de caso como base para indagações acerca da interpretação que as crianças fazem dos croquis de localização}

A escolha deste modo de investigação ocorreu pela necessidade de se intensificar o aprofundamento da atividade desenvolvida em campo. Foi necessário detalhar não só as características das crianças envolvidas na atividade, mas apresentar todo o contexto educacional da cidade de Diadema, complementando inclusive os dados de conjuntura do campo educacional brasileiro, buscando certa perspectiva de totalidade da situação do ensino de conhecimentos geográficos na Educação Básica, com ênfase na Educação Infantil.

45 Interpretação: no trabalho de Simielli (passim), interpretação das representações gráficas é processo que se segue a Leitura das cartas dentro das proposições da Alfabetização Cartográfica. Aqui menciono interpretação como categoria do campo sócio-histórico. Significa que entendo um processo de mediação através do qual a criança se apropria da linguagem das representações gráficas interpretando-as a partir dessa interação. Portanto, estou defendendo que esse processo de apropriação respeite as condições o processo de aprendizado das crianças, nas condições discutidas no capítulo anterior. 
Recorri a procedimentos como observação direta da escola, participando das atividades de alimentação convivendo com as crianças; realizei as entrevistas $\mathrm{cm}$ direção e gestores do sistema de ensino e desenvolvi atividade segundo as concepções sócio-históricas conforme já discutido anteriormente.

Trabalhei com algumas hipóteses, já apresentadas, e creio que ao término deste capítulo poderei apresentar alguns elementos de inferência que contribuem para generalizações, embora haja em tudo estudo de caso fatores contingentes. Neste caso a metodologia não se limitou a explorar o caso de uma escola em particular. Na verdade, a investigação dos aspectos do sistema de ensino revelara a oportunidade de introduzir uma atividade que permitiu a observação, a análise e a síntese dos dados obtidos, a partir de uma mediação direta entre pesquisador e sujeitos da pesquisa superando o risco da simples descrição, o que tende a ocorrer com essa metodologia.

\section{A Educação Infantil no município de Diadema - o contexto de realização do estudo de caso}

A Educação em Diadema está organizada para atender a Educação Infantil, Séries Iniciais, Educação Especial e EJA. O Município, que introduziu a diretriz de considerar a creche uma instituição de ensino e não de assistência social, desde 1991, portanto anos antes que isto fosse Lei Federal, desencadeou a organização do atendimento a criança de 0 a 6 anos, envolvendo a participação popular como um princípio norteador.

A experiência de gestão democrático-popular de Diadema deve ser compreendida para que aspectos essenciais do estudo de caso se esclareçam, adiante. De forma sintética, apresento as considerações de Bisilliat, autora do livro Lá onde os rios refluem - Diadema - 20 anos de democracia e poder local (2004), que realizou essa pesquisa com a finalidade de contar o processo de transformação da cidade e estudar a relação entre transformações sociais e tempo. Bisilliat é professora de Sociologia pela Universidade de Sorbonne e desenvolveu sua pesquisa a partir de 1995. 
Os excertos que utilizo abaixo foram extraídos de entrevista da autora a Fundação Perseu Abramo, que a publicou em seu sítio eletrônico. A autora aponta "um grande processo de transformação, de uma cidade caótica para uma cidade organizada. Com o tempo, Diadema passou a contar com espaços bonitos, praças, parques, coisas que no início não existiam" (2004).

Acrescenta que quanto às questões sociais, são muitos os avanços.

$\mathrm{Na}$ área da Saúde a implantação de políticas públicas contribuiu com uma queda expressiva da taxa de mortalidade infantil, que chegou a ser apontada como a mais baixa do Estado. As áreas de Educação e Habitação também mudaram bastante. Trazendo avanços no combate à violência e ao desemprego. Além disso, a proximidade da população em relação à Prefeitura, ao poder público, ampliou-se muito. Foram criados os chamados NAPs (Núcleos de Atendimento à População) em várias regiões da cidade, uma descentralização dos serviços que foi muito útil para os moradores $\mathrm{e}$ simbólica dessa relação de aproximação entre a Prefeitura e a população (BISILLIAT, Portal Fundação Perseu Abramo, 2004).

Considero as conclusões de Bisilliat, essenciais, para explicar as condições de organização do sistema de ensino local, bem como a importância da participação da população no processo de consolidação deste. Como a autora apontou, a população encontrou formas de participação decisivas para a implementação de políticas públicas educacionais.

A passagem das creches do campo da assistência social para o âmbito da educação exigiu dos profissionais de ambas esferas um elevado grau de discernimento para que a população compreendesse a importância de se oferecer educação a partir de 0 anos de idade, como direito essencial. 
Para garantir tal transição, assegurando às comunidades a possibilidade de compreender a essência dessas alterações de natureza política, as equipes decidiram denominar as creches de Escolas. Desta maneira introduziu-se, como já disse, com anos de antecipação, a idéia de direito da criança a Educação Infantil, marcando-se no âmbito das representações sociais a idéia de Escola e direito a Educação.

Denise Ferreira, responsável pelo setor de Educação Infantil da Secretaria Municipal de Educação, relata que o processo de organização das Escolas de Educação Básica passou por experiências que resultaram na participação das famílias na decisão de destinação de vagas, quando a relação demanda disponibilidade destas não garantia a todas o atendimento. Diadema pode vivenciar com a população local a reflexão sobre os níveis de necessidade e o estabelecimento de critérios para essa destinação.

Uma vez organizadas as escolas, passou-se a um trabalho de formação docente e de gestores, que resultaram na definição de Diretrizes Educacionais para a rede de ensino, possibilitando o delineamento das propostas curriculares. Neste momento a rede vive e delibera sobre essas propostas.

A Escola Serraria, assim denominada por localizar-se no Bairro Serraria, participa ativamente desse processo. Juntamente com a rede, entre 2004/2005, através de um processo de leitura partilhada das propostas curriculares, passaram a trabalhar na definição de eixos para a organização da Proposta Pedagógica da unidade.

A Secretaria de Educação, Cultura, Esportes e Lazer, de Diadema, definiu como eixo norteador de suas políticas A Democratização do Acesso e Permanência dos cidadãos à Escola, com qualidade Social da Educação, dentro de uma concepção de Gestão Democrática.

Outros 7 eixos foram definidos e propostos para que cada Escola pudesse construir sua proposta pedagógica, a partir desses eixos comuns. A Escola Serraria debateu todos eles e vem implementando sua Proposta a partir desse debate. 
Também merece registro a Concepção de Educação que a Escola propõe. Esta concepção revela que suas crianças têm lugar protagonista no processo ensino-aprendizagem.

A construção dos conhecimentos se dá a partir das necessidades e conflitos vivenciados na realidade, sendo construídos ao longo do processo. Uma educação de qualidade implica em transformação. A Educação Transformadora parte do que é significativo para 0 aluno. Considerando suas experiências pessoais e culturais e contexto social no qual a comunidade está inserida. É preciso que haja intervenção para chegarmos à transformação, em ambiente democrático, em que as diferenças sejam estimuladas de modo positivo, para o desenvolvimento da autonomia do aluno, a construção de sua identidade no exercício da cidadania. (Equipe Escola Serraria - 2006 - Plano Anual).

Outro trabalho reflexivo da Escola Serraria, relevante para o trabalho educativo, é a explicitação que fazem de sua concepção de Professor e Infância.

O professor de Educação Infantil da Escola Municipal Serraria busca uma ação institucional, voltada para o atendimento de qualidade para a criança pequena, articulando as necessidades para o seu desenvolvimento, garantindo o cuidado e a aprendizagem no planejamento.

A atividade educativa da creche inclui brincadeiras na rotina de forma intencional e não somente o brincar pelo brincar. É preciso também, considerar nos momentos de planejamento a integração entre as fases, propor situações nas quais os alunos possam expressar 
opiniões e comentários (rodas de conversa...), estimular a formação de hábitos saudáveis.

É fundamental planejar um contexto educativo envolvendo situações e atividades desafiadoras e significativas que favoreçam a exploração, a descoberta e a apropriação do conhecimento sobre o mundo, o conhecimento do próprio corpo e suas potencialidades.

Planejar é condição fundamental, sendo preciso conhecer os instrumentos de planejamento, avaliação e registro, reconhecendo-os como instrumentos essenciais para a avaliação do processo de desenvolvimento dos alunos, crianças e busca da qualidade na Educação. (Equipe Escola Serraria - 2006 - Plano Anual).

A indicação dessas concepções é altamente relevante para a análise do estudo de campo. A Escola trabalha com uma perspectiva teórica fundamentada em teorias da aprendizagem e do desenvolvimento infantil, que privilegiam as atividades, a intencionalidade da ação educativa, a condição de enfrentamento de conflitos e contradições da realidade como condição de transformação, a dimensão profissional da ação docente que inclui o desenvolvimento do Plano de Trabalho, registro e avaliação, como elementos nesse processo da relação ensino-aprendizagem.

Por fim a Escola destaca que considera fundamental manter indicado em seu Plano Anual de trabalho sua concepção de Inclusão Social. De fato quando a escola tem clareza deste aspecto sua ação educativa avança no sentido de desenvolver trabalhos, no âmbito da gestão, que tornam mais efetivas as ações destinadas a essa inclusão. Nos termos da Escola "a inclusão é para todos ao considerarmos que cada indivíduo é um ser único (com experiências, cultura, necessidades próprias) que aprende de formas diferentes". (Plano Anual, 2004). 
Creio que tal concepção revela a peculiaridade do pensamento e da prática educativa no município de Diadema. Ao discutir as questões relativas a inclusão social, avança nas questões de inclusão das necessidades especiais, mas também na inclusão das crianças que vivem outras dificuldades e especificidades havendo então essa diretriz essencial ao processo democrático que reivindica Inclusão para Todos.

Mais uma vez, recorro a Bisilliat (2004) para lembrar, através de uma pequena síntese que faço de seu trabalho, extraído do sítio da Fundação Perseu Abramo:

[...] que o caso de Diadema como história de uma experiência, mostra a força e o vigor que o método democrático e popular de governar uma cidade tem na sua transformação. Transformação que incide sobre a estrutura geográfico-física da cidade, sobre o ambiente de vida das pessoas, sobre suas condições de moradia e sobre o sentido de comunidade e de cidadania que elas passam a agregar nas suas subjetividades e nas suas relações interpessoais. A otimização de todas essas condições é o resultado do experimento de governos democráticos e populares. Como perspectiva de futuro, [...] mostra que vale a pena apostar no poder local e no desenvolvimento local como meios imprescindíveis de transformação da sociedade brasileira, no sentido da superação da pobreza e da constituição da cidadania e da justiça. O poder local é também a forma mais adequada para o aprendizado do exercício da democracia. É ali onde o cidadão tem mais possibilidade de exercer seu poder enquanto um agente ativo do processo político e enquanto um governando que estabelece níveis adequados de controle sobre os governantes (BISILLIAT, Portal Fundação Perseu Abramo, 2004) 
Os resultados da pesquisa de Bisilliet esclarecem questões do contexto sóciocultural que estudei, com vistas a compreender as características da escola em que realizei o estudo de caso. As transformações do Bairro Serraria, são evidentes e traduzem a construção dessa perspectiva Cidadã. Posso afirmá-lo pois foi o bairro da escola estadual de meu ingresso na rede estadual de ensino, em 1981. Não havia retornado ao Bairro desde 1982. Os fatos apontados nos breves relatos da pesquisa referida dão idéia e confirmam a profunda transformação do lugar.

Para ser coerente com as ações destinadas a Inclusão Social, a Coordenação da Escola, planeja visitas domiciliares de acompanhamento das crianças que não estejam freqüentes adequadamente. São estes procedimentos, dentre outros, que garantem os processos de transformação identificados por Bisilliet.

A Escola conta com Conselho Escolar, Grêmio Escolar. Sua equipe administrativa dá suporte aos processos da gestão. Uma medida muito significativa na experiência da gestão pedagógica da Escola, diz respeito aos horários assegurados para a Formação Docente. A Escola conta com 20 professoras e Educadoras de Educação Infantil. Há ainda as equipes que atendem Educação Especial e EJA. A Gestão está a cargo das Professoras Hélia (Cordenadora) e Sandra (Assistente).

A Escola possui uma estrutura física que vem sendo adaptada às necessidades de atendimento a demanda que se apresenta a cada ano. $O$ Bairro tem, segundo a coordenação da Escola, uma demanda reprimida em torno de 500 vagas. Esta escola atende a 240 crianças em tempo integral.

Em que pese tais dificuldades, a estrutura da Escola foi planejada para oferecer condições adequadas ao processo ensino-aprendizagem, como pode ser identificado nas Tabelas 2 e 3, a seguir. 
Tabela 2: Escola Serraria - Características Físicas

\begin{tabular}{|c|c|}
\hline \multicolumn{2}{|c|}{ CARACTERÍSTICAS FÍSICAS } \\
\hline Quantidade & Espaço \\
\hline 10 & Salas de aula \\
\hline 1 & berçário \\
\hline 1 & solário \\
\hline 1 & Sala de professores \\
\hline 1 & Biblioteca \\
\hline 1 & Sala de coordenação \\
\hline 1 & Secretaria \\
\hline 1 & Lactário \\
\hline 1 & Cozinha \\
\hline 1 & Lavanderia \\
\hline 1 & Dispensa \\
\hline 4 & Banheiros infantis \\
\hline 3 & Banheiros para uso adulto \\
\hline 1 & Pátio coberto \\
\hline 1 & Depósito \\
\hline 1 & Parque \\
\hline 1 & Área externa \\
\hline
\end{tabular}

Tabela 3: Escola Serraria - Recursos Didáticos

\begin{tabular}{|c|c|}
\hline \multicolumn{2}{|c|}{ RECURSOS PEDAGÓGICOS } \\
\hline Quantidade & Espaço \\
\hline 3 & Vídeos \\
\hline 2 & TVs \\
\hline 1 & Retroprojetor \\
\hline 2 & DVDs \\
\hline 1 & Microsystem \\
\hline 2 & Rádio gravador \\
\hline 2 & Computador \\
\hline 1 & Máquina fotográfica com zoom \\
\hline 2 & Amplificadores \\
\hline 1 & Microfone \\
\hline
\end{tabular}

Por fim a Escola mantém o Plano Anual de Trabalho (2006), que neste momento está em fase de reelaboração e, a pedido da Coordenação, deixa de ser apresentado na íntegra, em função das mudanças que ocorrerão. A opção 
de fazer excertos e pequenos relatos de aspectos relevantes do Plano atende a essa necessidade.

Compõem o Plano Anual, os Planos de Trabalho da Coordenação, dos Professores e Educadores, da Secretaria, dos Funcionários da Cozinha e Lactário, da Limpeza, do Conselho Escolar. Examinando esses Planos encontrei uma meta destinada às questões do espaço no Plano da Coordenação:

Quadro 1: Melhoria do Espaço Físico

\begin{tabular}{|c|c|}
\hline META & AÇÃo \\
\hline $\begin{array}{c}\text { Formar um espaço que priorize a qualidade } \\
\text { social em ambiente cooperativo com ênfase } \\
\text { ao trabalho coletivo. }\end{array}$ & Construção \\
Pintura \\
Instalações de divisórias
\end{tabular}

A preocupação da Escola com a organização do espaço físico, com medidas propostas para sua melhor adequação, revelam a clareza quanto as necessidades de circulação das crianças, o que respeita as ações protagonistas destas. Entretanto, mesmo no caso de uma experiência bem sucedida como esta, entraves da burocracia (legislação etc.) acabam por influenciar a resolução dos problemas que surgem.

Foi possível observar que a Escola, de fato, cresceu muito e foi adaptando seus espaços tanto para acomodar as crianças e o trabalho pedagógico, como para acomodar as ações da gestão. E a discussão da escola naquele momento buscava dar encaminhamentos a esses aspectos, para o ano de 2007, que se iniciava.

Além de apresentar os Planos de Trabalho de cada segmento da escola, o Plano Anual inclui a Proposta Pedagógica de Educação infantil, que interessa examinar. Para situar o leitor faço breve registro de suas características principais.

Esta Proposta Pedagógica está organizada a partir dos eixos já mencionados. Destaca os conteúdos referentes a Natureza e Sociedade, por interessar mais diretamente nas várias fases que a escola toma como referência para sua organização pedagógica. 
Esse conjunto de excertos da Proposta Pedagógica da Escola Serraria será referenciado mais a frente, quando da análise dos dados do Estudo. Para completar o relato do Projeto Pedagógico (chamado Plano Anual, no âmbito da gestão pedagógica) acrescento que esta se completa com um processo de avaliação baseado nos registros das professoras. Estes são relevantes instrumentos tanto para o processo avaliativo das crianças como para o processo de formação docente, que se realiza semanalmente na escola.

\section{Local e procedimentos do estudo}

Para produzir o croqui de localização trabalhado no estudo de caso, foi necessário conhecer a escola previamente, escolher um desenhista habilitado a incorporar os conceitos de caracterização desse tipo de representação gráfica e, após observação, produzir o material que viria a ser usado no estudo. Para tal atividade, o desenhista participou de todas as etapas de planejamento, incluindo a conversa com a coordenadora da instituição.

Foi produzido um croqui de localização do pátio interno da Escola Serraria. Apresento, a seguir, as duas versões de croqui trabalhadas. A primeira delas, com as crianças de 3-4 anos; a segunda, com as crianças de 5-6 anos.

Figura 1: Croqui de localização I - crianças de 3-4 anos

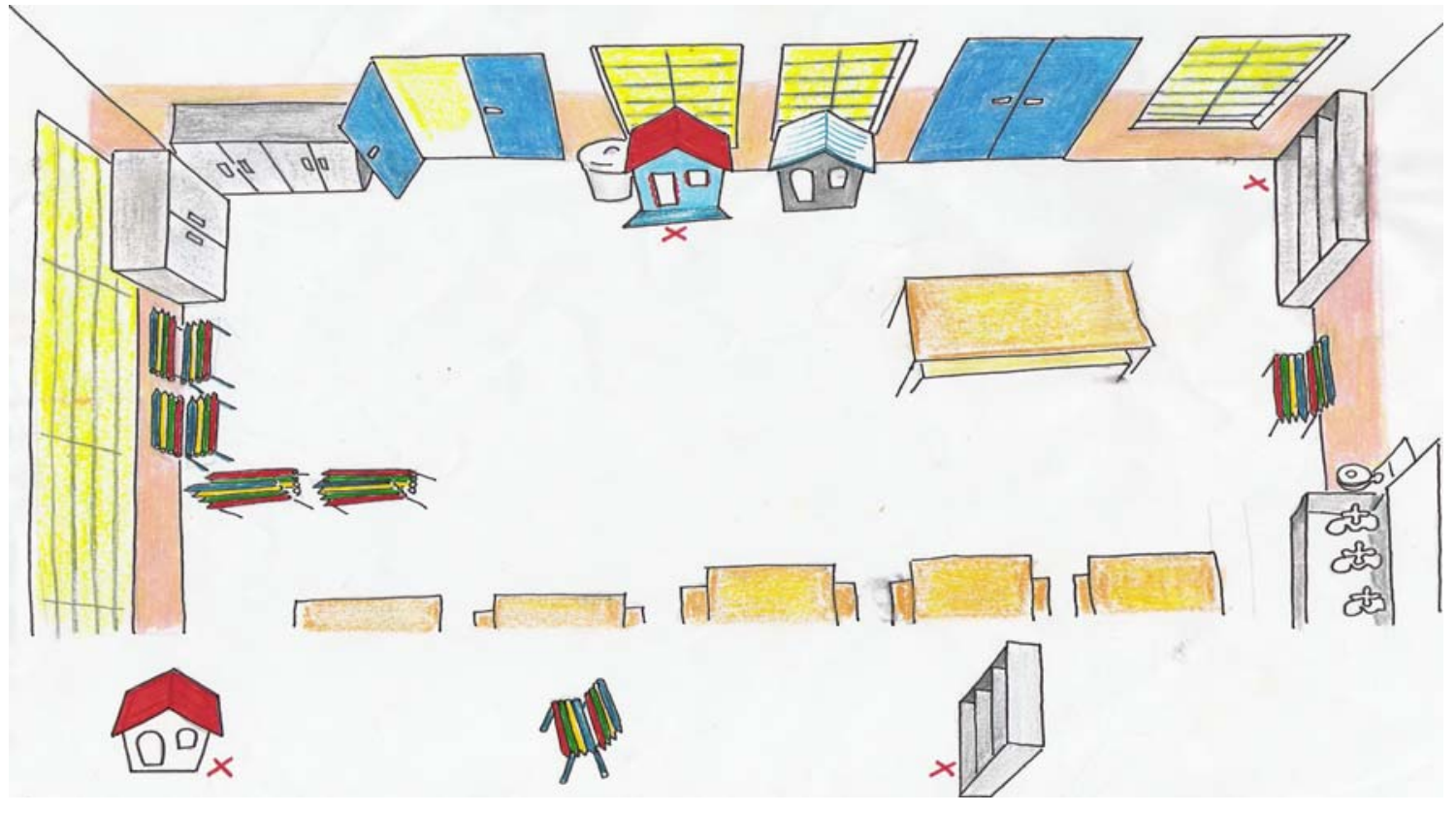


Como se pode observar pela representação, o pátio interno é organizado por espaços delimitados. Um conjunto de bancos coloridos é organizado em forma de $L$ quando as crianças vão desenvolver atividades simbólicas. Ali, no dia anterior ao da observação do espaço, havia acontecido atividades relativas ao escritório, organizado através de objetos que o representavam. Esses materiais ficam em um armário à esquerda, próximo aos bancos coloridos. Os outros elementos presentes no pátio são utilizados para diversas atividades organizadas neste espaço, como alimentação, higiene, convívio social, interação etc. É um grande espaço fechado, mas muito bem arejado e iluminado por grandes janelões.

Figura 2: Croqui de localização II - crianças de 5-6 anos

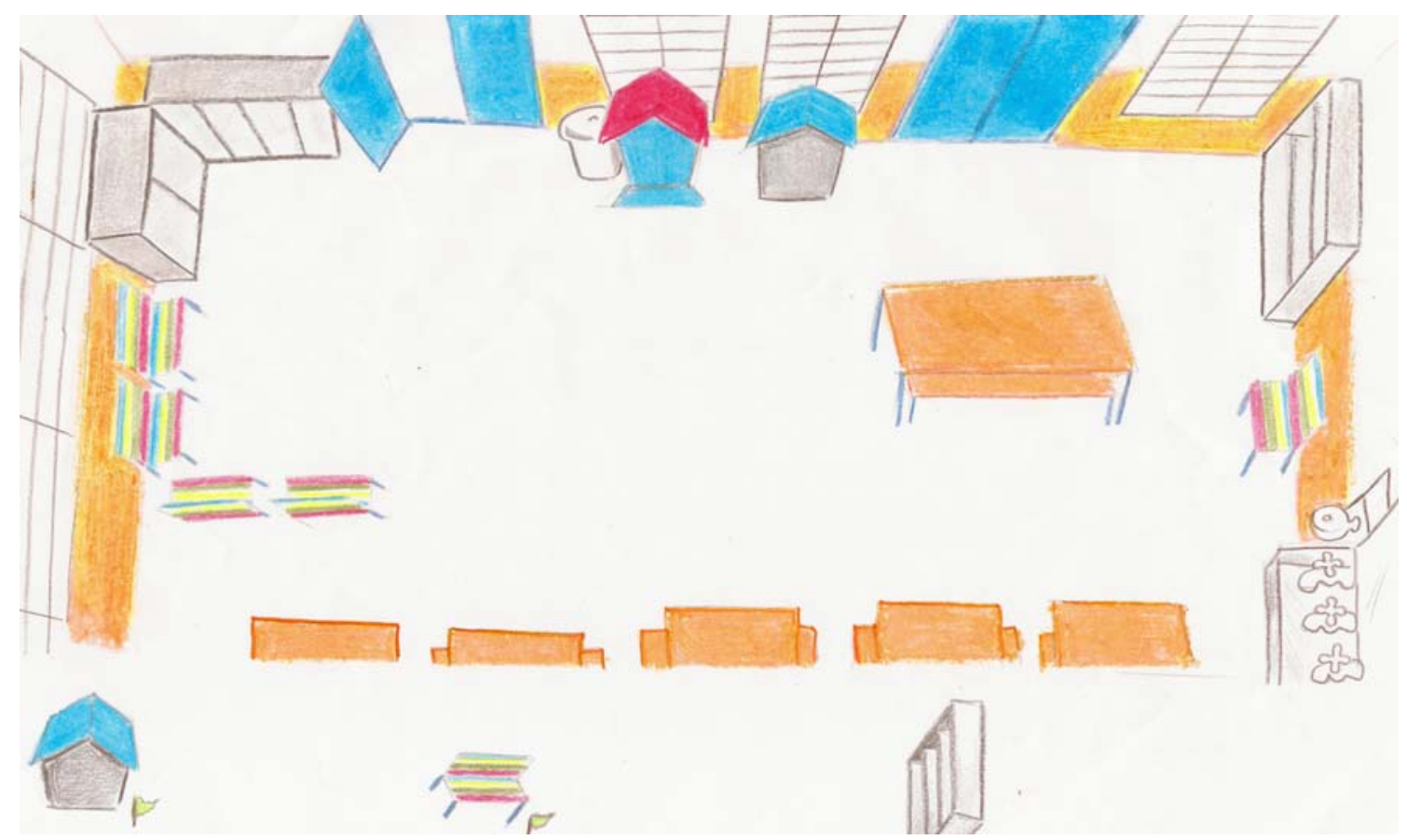

croqui foi elaborado a partir do mezanino, resultando numa representação que incorpora a visão oblíqua ${ }^{46}$. Tal visão é a mesma que se tem deste pátio quando se chega a ele, uma vez que o mesmo está construído em desnível. Essa construção em desnível se justifica porque o terreno da creche é uma pequena colina que se abre para o vale do Bairro Serraria. Em virtude desse

46 Visão oblíqua e vertical: todo mapa é uma "representação na visão vertical" (SIMIELLI, 1996: 45). No dia-a-dia vemos lateral e obliquamente. A visão vertical se apresenta através de representações do tipo aerofotogramétricos. A visão vertical se estabelece pela abstração. No caso do estudo de caso, foi utilizada visão oblíqua e vertical. 
desnível, a construção foi baseada em um projeto arquitetônico que recorreu à construção de dois pavimentos.

\section{A construção da atividade envolvida no estudo de campo}

A etapa de pré-teste na construção da atividade

A organização de atividade prévia partiu dos princípios que Vygotsky considera em seu trabalho Problemas de Método, do livro A Formação Social da Mente (1991: 70-74), que refere a necessidade de se organizar as atividades experimentais dos estudos científicos respeitando:

- Análise de processos e não de objetos - quando são considerados os aspectos envolvidos na dinâmica da atividade, é possível acompanhar a emergência de aspectos no processo psicológico que podem ser analisados a partir desse acompanhamento. Todas as sutilezas podem ser observadas e, portanto, não se faz uma análise de elementos separados da situação experimental.

- Explicação versus descrição - A descrição, típica da psicologia experimental, não revela as relações dinâmico-causais envolvidas nos fenômenos estudados, deixando de revelar sua gênese. Vygotsky ressalta que as diferenças entre os pontos de vista fenotípicos (descritivos) e genotípicos (explicativos), cujos fundamentos busca em Lewin, podem ser compreendidos quando se recorre ao exemplo relativo à baleia. Se descrevermos uma baleia, parece que falamos de um peixe. Se analisamos sua constituição e comportamento, ela se parecerá mais com uma vaca.

As distinções entre os pontos de vista fenotípicos e genotípicos foram problematizadas por Vygotsky, recorrendo inclusive a Marx, do qual cita: "se a essência dos objetos coincidisse com a forma de suas manifestações externas, então, toda ciência seria supérflua" (1991: 72). A manifestação externa a um estímulo deve ser analisada procurando-se compreender "as ligações reais com as respostas internas que são a base das formas superiores de comportamento" (1991: 72). 
Esse princípio, incorporado ao estudo pelo tipo de atividade de campo, realmente permitiu que se pudesse explicar as condições de realização do estudo e algumas dificuldades surgidas. A rigor, foi possível confirmar a importância do uso das representações gráficas no ambiente de aprendizagem, em atividade partilhada pelas crianças, tomando os croquis de localização como instrumentos mediadores e como elementos da mediação semiótica, fundamentais para o ensino.

- O problema do "comportamento fossilizado" - trata-se do princípio que procura manter a clareza sobre processos psicológicos mecanizados e automatizados que, sendo repetidos sistematicamente, já não podem ser compreendidos se apenas descritos em sua forma interna, já que os processos internos estão distantes. Segundo Vygotsky, os processos de atenção voluntária e involuntária exemplificam e esclarecem a importância de observar este princípio.

Uma abordagem fenotípica (descritiva) dos processos de atenção deixaria de encontrar a dinâmica causal que diferencia a atenção voluntária da involuntária, na medida em que, externamente, ambas se materializam de forma muito semelhante. Do ponto de vista do desenvolvimento, todavia, diferem profundamente. Assim, Vygotsky vai propor que, na atividade de pesquisa, haja uma concentração no processo e não no produto, a princípio, para que cada um deles possa ser interpretado corretamente, embora estejam relacionados, e permitam, considerada essa relação de forma adequada, reconhecer quais processos estão em desenvolvimento e quais foram incorporados numa função psicológica superior desenvolvida.

Também a observação deste princípio foi decisiva para o estudo de caso que realizei. Compreender as rotinas da escola para compreender os vínculos reais das crianças com o espaço representado revelou que as crianças traziam, através de suas experiências, condições de mobilizar atenção e memória ao interpretar a representação gráfica.

Em situação experimental cujo espaço não fosse o da vivência cotidiana, a qualidade da orientação poderia favorecer a solução da situação apresentada, e as crianças poderiam encontrar a surpresa. Todavia, não seria possível 
compreender as estratégias que cada criança criou, em função de sua experiência, para resolver a situação-problema, naquele que é seu espaço pessoal e coletivo. Histórico e cultural.

Para construir a atividade, um exercício, que chamo de pré-teste, foi realizado em uma pequena escola de Educação Infantil, da rede particular de ensino, na cidade de Santo André. A partir desse exercício foi possível comprovar alguns elementos essenciais para a definição da atividade.

Trabalhar com duplas de crianças com idade que respeitasse a paridade nas experiências escolares, interesses, características mais gerais do aprendizado e desenvolvimento, definindo uma dupla de 3 e 4 anos e outra de 5 e 6 anos, mostrou-se adequado. A hipótese confirmada é que crianças dessas faixas entrariam num processo de colaboração em que ambas poderiam atuar na solução da situação problema.

As instituições de Educação Infantil organizam-se, do ponto de vista pedagógico, para atender grupos de crianças adotando critérios relativos a faixa etária. Parte desses procedimentos estão embasados em fundamentos decorrentes das teorias do desenvolvimento infantil. Parte são decorrentes das práticas institucionais e das condições de atendimento da demanda. Procurei me basear nesses critérios e propus as condições deste estudo, tendo chegado a um consenso com a Coordenação da Escola, tanto no pré-teste, quanto na atividade de campo, definitiva.

Também foi nas ações dessa atividade prévia que se mostrou adequada a construção do croqui de localização, incluindo elementos pictóricos, de espaço significativo na experiência escolar das crianças. A atividade e seus exercícios respectivos foram planejados a partir dessa escolha.

Outra decisão tomada a partir dessa etapa prévia do estudo de caso, foi estabelecer a mediação a partir da interação entre pesquisadora e grupo de crianças. A princípio a hipótese era que a professora poderia aplicar os exercícios. Todavia trabalho com croquis não são usuais nesse nível de ensino 
o que exigiria uma etapa de capacitação docente que seria um transtorno para a dinâmica diária da escola.

Os resultados da atividade desenvolvida na escola de Santo André, Núcleo Educacional Brincar e Aprender, não foram tomados como referência. O que essa atividade prévia proporcionou foi a confirmação das decisões metodológicas mais adequadas, incluindo a filmagem da atividade.

Com a finalização da atividade prévia foi estabelecido um conjunto de parâmetros que resultaram na definição dos critérios para a escolha do grupo de crianças, no conjunto de procedimentos metodológicos e no processo de análise.

Todavia gostaria de registrar que no experimento piloto os resultados alcançados, em que as crianças levantaram hipóteses e usaram a referência do croqui para encontrar a surpresa, resultou na introdução de nível mais complexo através da sucessão de exercícios variados, como veremos.

A organização da atividade e sua finalidade

A atividade consistia em oferecer às crianças croqui de localização capaz de servir como instrumento relevante para a solução de uma situação problema, a partir da interpretação que as crianças pudessem construir.

A primeira etapa de construção do croqui envolveu a observação da escola e a decisão sobre qual seria o espaço representado. Conforme as figuras 5 e 6, decidi representar o pátio interno da escola. Ali se desenvolvem as atividades de alimentação, higiene, simbólicas, interação e convívio envolvendo atitudes, valores, entre as crianças e os adultos.

Os graus de complexidade para representá-lo incluiu: visão oblíqua de espaço superior para observar se isto consistia uma real dificuldade para a criança; uso de apenas alguns elementos mais representativos do espaço (mesas e bancos, lavatórios, armários, casinhas e lixo) além dos elementos da arquitetura mantidos. 
Na Figura 1 (p. 135), a representação foi bastante detalhada e fidedigna aos elementos concretos. A Figura 1 (p. 136) alterou algumas informações. Em ambas foi introduzida uma legenda, que significou graus de dificuldades diferenciados para as duplas de crianças, na execução dos exercícios.

A Figura 1 apresenta uma legenda em que os elementos possibilitaram a interação pesquisadora-crianças na orientação para a solução da situação problema. Na Figura 2, as crianças valeram-se das informações apresentadas e não houve interação no processo de interpretação, por iniciativa da pesquisadora. Esta ocorreu por iniciativa das crianças.

Cada dupla desenvolveu uma atividade, que poderia ter até três exercícios:

- Exercício 1: Manejo, observação, conversa, perguntas, comentários e manifestações diversas a partir desse manejo com a interação da pesquisadora em ambiente fechado, fora do pátio.

- Exercício 2: Observação do croqui estando diante do espaço real ali representado, confrontando-os, partir do mezanino sobre esse pátio, portanto em visão oblíqua.

- Exercício 3: Manejo do croqui para resolver a situação problema que consistia em localizar uma caixa de bombons "escondida" no pátio, utilizando as referências construídas ao longo dos exercícios 1 e 2 .

Foram organizadas, portanto duas atividades. Vou chamar de Atividade A o trabalho a dupla de crianças mais jovens ( 3 e 4 anos) que se desenvolveu através dos três exercícios. A Atividade $B$ se deu com a dupla de crianças mais velhas ( 5 e 6 anos) e não foi necessário cumprir o exercício dois.

Desenvolvimento da atividade

Para participar da atividade foram escolhidas as crianças, que por motivos legais, preservo quanto à identidade. Na Atividade A, participaram E (3 anos), do maternal, e M (4 anos), da Fase I, como primeira dupla. A Atividade $B$ contou com R (5 anos) e W (6 anos), das Fases II e III, respectivamente. 
A Escola informou que a partir da solicitação, mediada pelo Departamento de Educação Infantil, as professoras foram sensibilizadas a indicar crianças que se sentissem à vontade em contato com pessoas de fora e desenvolvendo atividades sem a presença da professora e das educadoras.

É importante acrescentar que a Escola Serraria foi indicada pelo Departamento, também por desenvolver, em sua proposta pedagógica, estudos do meio envolvendo sua comunidade. Assim duas informações consolidam os critérios de indicação das crianças; havia atividade escolarizada suficiente para se tratar as questões envolvendo espacialidades, com crianças que demonstravam ficar a vontade em atividades educativas dessa natureza.

Após conhecê-las nos acomodamos na sala dos professores, em torno de uma grande mesa, com a câmera ligada. Quando necessário manejei a câmera pessoalmente. Lembro que estávamos em sala fechada, distante do pátio representado no croqui.

Nesse momento o exercício consistia em dialogar com as crianças e compreender como a representação do espaço escolhido ativava a percepção, a atenção, a memória e como comunicariam suas observações, hipóteses, lembranças, o que constitui o processo de interpretação, a partir do manejo do croqui, conforme descrito acima.

O primeiro comportamento das crianças com relação a representação gráfica foi de certa timidez em entrar em contato com o material. Ficou claro que as crianças foram orientadas a agir de acordo com as orientações da pesquisadora. Identifiquei que caberia a mim criar condições para a interação.

Evidenciou-se que as crianças têm trabalhado as questões de convívio. As quatro crianças focaram sua atenção nos exercícios propostos. E, o mais jovem, e, portanto, com processo de escolarização mais recente, deixou de seguir os passos propostos pela mediação e passou a atuar na direção de seu interesse. 
O estudo ocorreu em ambiente contextualizado, respeitando-se as rotinas das crianças. As regras de convívio, com exceção de $\mathbf{E}$, foram observadas pelas crianças, de modo que demonstraram o domínio dessas atitudes e valores, construídas na experiência histórica e cultural que a escola procurou assegurar.

Em qualquer outra situação, a atuação das crianças estaria marcada pela emergência de aspectos experimentais, provavelmente vinculados a relação pesquisador-criança-ambiente, de laboratório. Neste caso, desenvolveu-se uma atividade própria do contexto escolar e de uma etapa definida da Educação Básica. As crianças foram acompanhadas em sua relação cotidiana com seu meio e seus parceiros permanentes. O comportamento de observação de regras somente comprovou que as crianças mais velhas já sabem fazer distinções entre situações de rotina e aquelas que incluem visitantes.

A criança de 3 anos precisou de um tempo para manejar a câmera de vídeo, momento em que foi necessário interromper a filmagem. Esse interesse insistente da criança foi incorporado ao trabalho e criou uma nova condição no processo de desenvolvimento da atividade. Uma situação afetiva, nova, se criou entre as crianças e a pesquisadora.

Esse episódio revelou que as crianças desenvolveram um grande interesse pela imagem representada. A criança de três anos interpretou que a imagem (croqui) observada seria produto da câmera. Associou o croqui a um artefato do tipo fotográfico e quis ver dentro da câmera, para checar as imagens. Este é um ponto a ser analisado adiante.

A descrição deste fato é importante para compor o contexto de realização da atividade. A criança levantou uma hipótese e criou estratégias para checá-la.

O segundo exercício consistia em propor às crianças observar o lugar real e confrontá-lo com a representação, observando a partir do mesmo local em que foi elaborado o croqui de representação. Nesse momento de diálogo, chamei a atenção das crianças para a legenda organizada na representação. Aí, o 
objetivo era certificar-me de que as crianças reconheciam o espaço representado e o espaço real.

As crianças maiores não se detiveram nesse segundo exercício. Já haviam compreendido a lógica do croqui e diante da confrontação proposta entre a representação do espaço concreto, rapidamente informaram que se tratava do lugar vivido e representado.

O terceiro e último exercício consistiu em retomar o croqui de localização e trabalhar a partir da legenda, para encontrar caixas de bombons. Eram 4. Estavam escondidas em duas casinhas de brinquedo (uma no teto da casinha vermelha, outra num canto da casinha azul, sob um banquinho). Outra atrás de um dos bancos encostados no grande janelão à esquerda, na representação (o banco mais próximo do armário) preso às costas e uma quarta em uma caixa de papelão em meio a outras, num armário de materiais, aberto, no canto direito do croqui.

A situação-problema a ser resolvida apresentava o desafio para que as crianças procurassem a surpresa oculta no espaço do pátio. Para a primeira dupla de crianças (3 e 4 anos), tal busca deveria partir da representação e das informações da legenda, que completei durante a mediação. Para as crianças mais velhas, a legenda, fundamental para a resolução da situação-problema, estava pronta e as crianças deveriam considerá-la a partir da orientação mais geral que foi oferecida.

Os níveis de dificuldade foram pensados a partir da hipótese que em interação, as crianças poderiam utilizar os croquis e localizar as caixas mesmo que enfrentassem graus de dificuldade variadas. Por fim esclareço que a análise dos dados foi construída de maneira seqüencial. Devem ser compreendidas como um conjunto. Organizei a análise através das atividades, apenas para esclarecer aspectos da atuação de cada dupla.

Há algumas considerações que são pertinentes ao desenvolvimento de crianças em situação de aprendizagem, na educação formal. Portanto, as ponderações sobre ZDP são compatíveis com o trabalho das duas duplas. 


\section{Apresentação e análise das situações de interpretação do croqui de localização}

\section{Atividade A}

As crianças $\mathbf{E}$ (menino de 3 anos) e $\mathbf{M}$ (menina de 4 anos) formam a primeira dupla a participar do estudo. Na condição de mediadora da atividade, identificome como A (adulto pesquisador).

\section{EXERCÍCIO 1}

E e $\mathbf{M}$ são, inicialmente, recebidas numa sala com uma grande mesa, em torno da qual nos sentamos.

O croqui de localização é oferecido às crianças. $\mathbf{E}$ e $\mathbf{M}$ permanecem sentados, observando e manuseando o croqui. Por alguns minutos, $\mathbf{M}$ gira o croqui até posicioná-lo de forma satisfatória ao seu ponto de vista. A pesquisadora introduz algumas indagações sobre se as crianças conhecem algum lugar parecido com aquele ali representado.

E - (apontando para o teto levemente inclinado para a frente) É de lá.

O gesto de $\mathbf{E}$ parece aleatório, mas indica sua lembrança de um espaço conhecido e ali representado. A fala surge como linguagem e mediação do ato da compreensão. É de lá é um signo mediador que $\mathbf{E}$ utiliza para pensar e interpretar o que acaba de perceber.
A - (para
E) Você conhece esse lugar?
(E e M manejam o desenho e batem com os dedos sobre cada um dos elementos representados)
E - Conhece.
M - Conheço. 
Os gestos das duas crianças, apontando para os elementos reconhecidos, vão revelando a emergência do processo perceptivo. $O$ ambiente escolar em sua dimensão cultural também mediatiza, por meio da figuração (representação gráfica apresentada), os significados que cada um dos elementos possui para cada uma das crianças.

A mediação semiótica que $\mathbf{E}$ e $\mathbf{M}$ organizam por meio de sua percepção, memória e atenção se constrói a partir dos conteúdos culturais que a representação gráfica, instrumento de mediação técnica e semiótica, ativou para que as crianças pudessem reconhecer os lugares representados.

O gesto de apontar e bater sobre cada um dos elementos representados, sobretudo para $\mathbf{M}$, pode revelar a emergência da imagem mental desses lugares. Ao lembrar dos lugares freqüentados no dia-a-dia, a figuração de cada elemento da representação gráfica transforma-se em signo e a interpretação croqui de localização torna-se possível.

A interpretação será, então, um recurso poderoso para que cada criança amplie as condições para inventar, imaginar e criar, ela própria, formas pessoais para expressar suas experiências culturais, segundo sua realidade e seus saberes.

Atividades assim planejadas e propostas podem favorecer os processos de constituição da linguagem e do pensamento na criança pequena. A observação destes processos é essencial ao debate sobre a mediação como fundamento da didática. Evidentemente a mediação é conceito de Vygotsky relevante per se, não em função do contexto educacional contemporâneo. A questão, na verdade, é que, frente às demandas atuais, certas "pedagogias" não respondem as necessidades de entendimento da relevância do conceito, porque têm outras concepções de mundo, de sujeito, de aprendizagem, de desenvolvimento, de aprendiz, de professor...
A - (apontando para o croqui) Onde é esse lugar?
E - (apontando para a câmera) É lá.
M - (apontando para a porta) É aqui. 
O excerto acima revela duas questões absolutamente essenciais para este estudo: a fala é aspecto central no processo de desenvolvimento da criança pequena e cada criança percorre uma trajetória pessoal, o que nos desafia a considerar os equívocos que se pode cometer quando a ação pedagógica parte da concepção que haveria condições universais de desenvolvimento que tornariam todas as crianças indivíduos desenvolvidos pelo mesmo processo.

Outro aspecto fundamental, de natureza metodológica, diz respeito àquela questão do descrever e do explicar. Numa perspectiva fenotípica, que medisse o momento em que as crianças pudessem expressar a lembrança de um lugar conhecido pela exposição ao croqui de localização, diríamos que ambas resolveram a situação.

O que vemos, entretanto, considerando o processo da fala, é que cada uma organizou sua percepção, sua memória e atenção situando o lugar da lembrança de forma diferenciada. Para E, o lugar é lá porque, segundo minha interpretação, ele relacionou o croqui a fotografia. E, desde o início do exercício, demonstrou fascínio pela câmera. Apontou sistematicamente para a câmera quando dizia é la.

Para M, dizer é aqui apontando com o braço inclinado em direção a porta, pode revelar que seu processo de pensamento (atenção, memória, percepção) se refere à porta como elemento de distanciamento do espaço representado, por inferência.

Ao apontar para o alto e dizer é lá, E unifica através de sua percepção, ação e fala a interpretação de que o croqui poderia ter sido produzido por aquela câmera. A explica a E que aquela é uma máquina de filmar e não de fotografar. Que ele vai poder olhar e que deve esperar a hora certa. Concomitante a esse diálogo, M está absorta manejando o croqui. Após a intervenção de A, E volta a brincar com o croqui.

Quando M diz é aqui apontando para a porta (que dá acesso ao mezanino de onde se avista o pátio), revela que sua experiência, permite-lhe situar o lugar 
representado de acordo com a realidade objetiva, através de uma fala que é, que organiza seu pensamento demonstrando uma função diretiva deste.

O croqui de localização, ao mediar o processo de interpretação, pela ativação das funções superiores das crianças envolvidas, permitiu a compreensão do processo de desenvolvimento peculiar a cada criança. O processo de internalização, que pode ser compreendido como apropriação e significação segundo Smolka (2000):

Internalização, como um constructo psicológico, supõe algo lá fora - cultura, práticas sociais, material semiótico - a ser tomado, assumido pelo individuo (SMOLKA, 2000: 28)

Tanto no caso de $\mathbf{E}$ como no caso de $\mathbf{M}$, o uso do instrumento e dos signos permitiu trazer, para o presente, lugares, objetos, situações ausentes. Sobretudo, ao prestar atenção nos elementos pictóricos da representação, as crianças usaram a fala aberta em sua função comunicativa contribuindo para a reflexão da criança sobre o que está observando e que lhe suscita a lembrança. Antes de dizer é lá ou é aqui, as crianças olharam para diversas direções da sala. M fixou sua atenção na porta e em seguida indicou é aqui. $\mathbf{E}$ olhou para o alto, apontou para cima, apontou para a câmera e então disse é lá. Vejamos esse momento na interação com E.

E - (insistindo e apontando para a máquina) É de lá. (faz o movimento de clique comum à maquina de fotografar e insiste) Faz assim e é de lá.

O que $\mathbf{E}$ quis dizer, diferentemente de $\mathbf{M}$, é que a representação era uma espécie de fotografia de um lugar que ele conhecia. Deixou de dizer é lá e resignificou sua interpretação esclarecendo que era de lá, da câmera. O que E ajuda a compreender, ao reelaborar sua fala, são os indícios das mudanças qualitativas nas relações de reciprocidade entre discurso e cognição. 
Após ouvir a explicação de $\mathbf{M}$ de que o croqui representava algo que era aqui, $\mathbf{E}$ preferiu reconstruir sua hipótese e atribuir a representação gráfica à máquina. Afinal, em sua experiência, imagens que se pode manipular são fruto da mediação da máquina de fotografar. Lembro que a Escola Serraria trabalha atividades simbólicas. A representação que utilizei era pictórica, portanto os elementos figurativos remetiam a certa fidedignidade entre as imagens representadas e 0 real. E conhece alguns instrumentos tecnológicos que produzem imagens. Demonstra muito interesse por imagens assim produzidas. Assim insistiu em sua hipótese que o croqui poderia ter sido produzido pela filmadora.

Em E a força das emoções é muito presente. Levanto a hipótese que por não estar num processo de escolarização mais elaborado como sua parceira, pode lidar mais afetivamente com a situação, lutando por comprovar sua hipótese. Embora tenha se convencido que não havia relação entre o croqui e a representação, atuou no sentido de ver dento da máquina.

E confirma o pressuposto de Vygotsky que formas de diferenciação na ação favorecem o desenvolvimento quando pares mais capazes proporcionam essa diversidade de experiências ao individuo. Isto significa que a situação social influencia as atividades que as crianças desenvolvem e que estas redirecionam essas atividades de acordo com suas hipóteses, memórias, percepções.

Foi o que aconteceu a dupla E e $\mathbf{M}$ Em situação de aprendizagem, este seria o momento de se organizar a mediação docente e transformar o trabalho com estas hipóteses num rico percurso formativo ancorado na experiência e no uso de signos fundamentais para os processos psicológicos, enraizados na cultura das crianças.

A mediação de A torna-se então estratégica, para reconduzir a tarefa.

A - (refazendo a pergunta) Vocês conhecem algum lugar parecido com esse?

M - Conheço. É de carro.

E - É de comida. (apontando para a representação do banco que usam para as refeições) 
M - Não, olha E (apontando para o armário), as roupas estão aqui dentro.

A - Onde estão as roupas?

M - Aqui dentro. (aponta novamente para o armário)

Quero destacar aqui esse processo de relações mediadas criança-criança, criançaA que desencadeou um processo de mediação em que as crianças passaram a explorar os aspectos que lhes pareceram relevantes, do croqui de localização.

Minha preocupação em "conduzir" as crianças a co-relacionarem o croqui e o lugar representado - pátio - criou uma dificuldade que $\mathbf{M}$ parece ter resolvido, esclarecendo que há outro lugar parecido com aquele e que se chega a ele de carro. Reconheço que minha pergunta comporta a resposta de $\mathbf{M}$ e entendo que esta é pertinente.

Quando afirma conhecer um lugar parecido ao qual chega de carro, $\mathbf{M}$ quis dizer que havia um outro lugar parecido. A intervenção de $\mathbf{A}$ confundiu a criança, que já havia dito que o lugar representado era aqui. Isto demonstra que, ao mediar com a turma e conduzir processos coletivos de diálogo, é importante observar as contribuições pessoais de cada participante da situação ensino-aprendizagem, favorecendo o percurso singular que cada individuo constrói.

E intervém dizendo é de comida. Após observar a representação, conclui que o lugar era de comida porque, de fato, a função principal do espaço representado é servir às refeições realizadas na creche. Tendo observado esse momento, anteriormente, fica claro que se trata de uma atividade vital para as crianças. Seguramente, é o lugar em que o binômio educar-cuidar melhor se configura.

Nos momentos de refeição, as crianças são acompanhadas pela professora da turma, mas orientadas a desenvolver a tarefa do auto-serviço. Esse lugar da comida que $\mathbf{E}$ reconhece prontamente no croqui revela sua experiência no ambiente. Indica sua percepção, seu foco de atenção, interesse e lembranças desse vivido. Daí expressar sua interpretação dizendo é de comida por ser essa situação a que tem significado relevante em sua experiência no lugar. 
Essa experiência constitui uma parte importante da espacialidade das crianças na escola. Organizadas em fila, todas se servem dos alimentos do cardápio do dia e dirigem-se sozinhas aos bancos, em volta das mesas de refeição. São desafiadas a manejar adequadamente os talheres de servir nos pratos, o prato e seu talher pessoal, a condução desse conjunto até chegar ao seu lugar.

Todos esses instrumentos de mediação desencadeiam um processo psicológico cuja origem social permite a criança controlar seu comportamento e aprender a relacionar-se com seu grupo de referência, em condições paritárias e afetivas, comendo, saboreando, conversando, interagindo com seus professores e alcançando sucesso sempre que dominam o conjunto de tarefas desse momento. Terminada a refeição, devem deixar o prato e talher em lugar próprio.

Observei que a refeição é saborosa. Servi-me dela também. Além do arroz, feijão, macarrão, carnes, verduras e legumes, há sobremesa. Faz muito sentido E valorizar esse momento de sua vivência diária. 0 importante é perceber que ele o fez diante da possibilidade de ter escolhido outros focos. Esse traço de identidade, favorecido pelo tipo de material - o croqui -, remete à questão de se destinar 0 material didático adequado a cada conjunto de conteúdos que se esteja desenvolvendo. Para discutir o lugar como uma dimensão que introduz o conhecimento de mundo, os croquis são importantes instrumentos de mediação.

Portanto, vemos que a decisão política por oferecer refeição através de um sistema de auto-serviço cria para a criança a oportunidade de estabelecer relações mediadas com seus pares e com os educadores que thes garante acesso efetivo a uma formação cidadã, para a qual o desenvolvimento do processo psicológico é vital.

Vou retomar aqui a intervenção de $\mathbf{M}$ seguida à de $\mathbf{E}$. Ela diz:

M - Não, olha E (apontando para o armário), as roupas estão aqui dentro.

No diálogo com seu amigo, $\mathbf{M}$ preocupa-se em alertá-lo que não, aquele não é lugar da comida. E sim da brincadeira. Embora M tenha localizado o armário, o 
que ela vê, recorrendo a sua memória do que há dentro do armário, são as roupas que usam em suas brincadeiras (atividades simbólicas organizadas pelas professoras nesse grande espaço, após as refeições e uma vez por semana).

As crianças entram, portanto, num processo comunicativo através do qual cada uma constrói as bases de sua interpretação. Esse processo de mediação foi o que Vygotsky identificou como essencial para se compreender o processo de aprendizado e desenvolvimento.

Cada uma das crianças internalizou aspectos diferentes de sua experiência no pátio em que se alimenta, brinca, convive, fantasia, imagina etc. e esses modelos internalizados foram ativados para interpretar a representação do lugar $^{47}$ a partir da originalidade de cada uma delas, mas sempre com relação à presença do outro, através da mediação, entendida amplamente nesse processo de apropriação dos sentidos daquele espaço.

Nesse processo de apropriação $\mathbf{M}$, refere-se às roupas que estão guardadas no armário à esquerda do croqui. Confirme com a Coordenadora e de fato, nesses armários são guardadas as fantasiais utilizadas no Teatro, nas dramatizações. Esse repertório é comum a $\mathbf{M}$ que vive tais experiências desde o ano anterior. A mesma situação vai ter inicio em 2007 com E.

Veremos adiante que $\mathbf{M}$ constrói uma narrativa envolvendo diversos personagens que parecem surgir de dentro desse armário que a criança sabe guarda o conjunto de roupas das representações de teatro que a escola organiza.
A - E o que mais vocês conhecem desse lugar?
E - Casinha. Tem casinha.
M - (prontamente, começa a apontar com o dedo cada uma das representações e a nomear os elementos pictóricos) Lixo, casinha, casinha e ota mesa, ota pota ota janela (pula o armário da direita e acrescenta) ota casa de brincar oto banco).

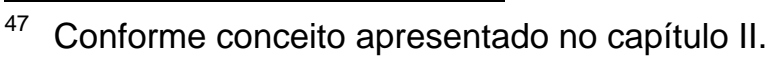


E - (fala concomitante a M) Tia, tira foto minha?

M - (continua indicando) ...e o sabão de lava mão e depois vem banheiro.

$\mathbf{A}-\mathbf{E}$, você viu que a $\mathbf{M}$ achou o caminho de ir pro banheiro?

E - (prestando atenção na representação) é onde lava mão e vai no banheiro.

Observa-se que a nomeação feita por $\mathbf{M}$ está ancorada no croqui a partir do momento em que ela percebeu o conjunto. Encantou-se com a sucessão de elementos representados e foi nomeando-os sem interrupção. A análise desse segmento deixa claro que $\mathbf{M}$ reagiu à pronta afirmação de $\mathbf{E}$, quando este disse que o lugar representava a hora das refeições. Durante todo o tempo que se seguiu, $\mathbf{M}$, de certa forma, falava com $\mathbf{E}$ sobre todas as outras possibilidades figurativas presentes naquela representação, que ela foi interpretando.

Há esse momento em que as duas crianças parecem focar a atenção no mesmo conjunto figurativo (porta-sabão e torneiras) e concordam que esses elementos remetem a higiene e ir ao banheiro. Pode-se afirmar, que esta situação caracteriza o desenvolvimento proximal, visto como desenvolvimento emergente, com a participação do outro num processo de elaboração compartilhada.

Agora, as crianças falam juntas. M procura impor sua observação. $\mathbf{M}$, ansiosa, encontra a representação do porta-sabonete e insiste em falar:

M - Ó esse é pa pô sabonete e lavar a mão assim, ó! (imita gesto de lavar).

A intensidade com que $\mathbf{M}$ procura comunicar seu achado (o porta-sabonete) revela que, assim como $\mathbf{E}$ com relação à comida, o croqui de localização permitiu a ela compreender e interpretar o conjunto figurativo, experimentando o encantamento de ver surgir um lugar significativo que conhecia e dominava, a partir de sua perspectiva histórica e cultural. As crianças demonstraram valorizar o espaço de sua refeição e higiene tanto quanto o da brincadeira. Atribuíram significados muito relevantes aos elementos representados, recorrendo à memória.

Constatado que as crianças se apropriaram dos significados do croqui e que interpretaram a representação apresentada, considerei o Exercício 1 concluído. 


\section{EXERCÍCIO 2}

Diante do espaço representado, apresento novamente o croqui e proponho:

A - Lembra que a gente viu que esse desenho era parecido com o lugar de almoçar? Será que é mesmo?

M - (olha a representação e o espaço que observamos de cima, em visão obliqua).

E - (solicitado a fazer o mesmo, responde) O banco... tia. (é a única observação que faz a partir da intervenção de A) Tia, deixa eu ver o filme... (apanha o microfone da filmadora e praticamente pendura-se na câmera).

Por limitação técnica não é possível continuar gravando (E interrompe a gravação apertando todos os botões que encontrou). Sua atitude é encantada. Está disposto a conquistar o direito de ver o que deseja ver. Respeitando sua necessidade, mostro a ambos passagens do que já gravamos. M parece preocupada com o comportamento do colega. Mas também se rende a oportunidade se observar dentro da máquina.

Este episódio não fora planejado. Na atividade de pré-teste, a filmadora fora ignorada pelas crianças, como também o foi pela dupla das crianças maiores, neste mesmo experimento. Observando as cenas é possível compreender que a câmera provocou uma mediação, enquanto instrumento técnico e semiótico, que fez o processo de atenção voluntária de E dirigir-se para esse foco. Ele sentiu necessidade de comprovar suas hipóteses de que sua imagem (fotografia?) estaria ali registrada. A coordenação da escola esclareceu que é comum fotografar-se as crianças. E que elas apreciam rever essas imagens.

E construiu parte de sua experiência com $\mathbf{M}$ e $\mathbf{A}$ introduzindo uma tarefa que "inventou". Olhar pelo visor da câmera para certificar-se do que estava ali dentro. Primeiro imaginou que o croqui fosse uma espécie de fotografia que teria saído de dentro da câmera. Após sucessivos esclarecimentos da parte de A e da exploração da representação construída pela mediação com $\mathbf{M}$, abandonou essa hipótese. Mas, observando o manejo da máquina por parte de 
A, convenceu-se de que a pesquisadora estava registrando sua imagem. E organizou-se para agir alcançando o microfone e torcendo o foco da lente para si. Depois, percebeu que havia um visor com sua imagem.

Este episódio indica que a atividade previamente planejada para todas as crianças foi percebida de forma diferenciada por $\mathbf{E}$, isto confirma a proposição de Vygotsky que:

1. a mediação é decisiva para diferentes modos de elaboração da interpretação. Neste caso o croqui de localização provocou formas particulares de atuação de cada criança na situação de interpretação, mas também confirma similaridades de comportamento quando cada uma delas recorre a sua experiência cultural, social para planejar essa atuação.

2. O comportamento de $\mathbf{E}$ remete as considerações de Cole (1990) para explicar a utilização de noção de ZDP, que parece ser pertinente para compreender o que aconteceu com E.

Caso se considere que o exercício, embora não tenha tido como objetivo criar a zona de desenvolvimento proximal, ativou as funções psicológicas superiores, que é o ponto ora investigado, será importante considerar algumas características da ZDP para compreender que:

a) esta permite entender a possibilidade de que alguém participe em atividades que, em sentido estrito, seria incapaz de realizar por si só (motivo pelo qual, considerando outras concepções, se afirmaria a impossibilidade dessa experiência). Tal participação pressupõe a outra pessoa com uma capacidade e uma responsabilidade diferenciada na atividade, condição que atribuo a E.

b) Como a ZDP é produto da interação, se entende que não implica uma seqüência predeterminada de ações nem papéis fixos para os participantes (em particular, quanto ao papel das ações e conhecimentos do adulto).

c) Como produto interativo, a ZDP destaca a inadequação de tomar só a perspectiva do adulto ou só a perspectiva da criança na análise do processo que ocorre entre eles, quer dizer, supõe um significado específico de interação que não pode reduzir-se a uma das perspectivas isoladas dos participantes. 
d) Como produto da interação a ZDP não implica uma dimensão temporal irredutível ao aqui e agora, sintetizando o presente com o passado e o futuro, síntese que se realiza sem plano predeterminado.

e) Permite repensar o desenvolvimento como uma ramificação complexa intimamente vinculada a categoria de contextos que podem ser negociados por uma pessoa ou grupo, em vez de como um escalão ou etapa homogênea dentro de uma progressão que permeia a totalidade das possibilidades do individuo.

A intervenção de $\mathbf{E}$ remete a essa reflexão, na medida em que esses pressupostos da ZDP, são em realidade pressupostos do próprio desenvolvimento. Ele retoma a atividade reconfigurando sua lógica. E isto foi relevante para compreender que $\mathbf{E}$ traz uma sofisticada condição de desenvolvimento, sobretudo por se ter confirmado, que seu repertório cultural vem sendo construído na escola, onde passa a maior parte de seu tempo.

Creio que é possível inferir que E expressa a possibilidade da inclusão social pela via da construção do conhecimento, quando o processo político aí envolvido está baseado nos princípios da participação, da transformação e organização dos coletivos, envolvidos no processo cultural e histórico do lugar.

Destaco que E confirma os pressupostos de Vygotsky, Luria e Leontiev, que sustentam a importância dos processos psicológicos mediados culturalmente que se desenvolvem historicamente surgindo a partir da atividade prática, conforme vimos no Capítulo I. Volto a situação com M, lembrando que estou apresentando aspectos seqüências dos exercícios desenvolvidos com as crianças:

A. - Esse desenho é parecido com algum lugar que você conhece?

M - Conhece. É... E, ó, conhecio é da folestra.

A - Qual floresta?

M - É de lobo. É de quando o chapeuzinho pega o bolo. 
Conforme visto no Capítulo III, a memória é elemento essencial para se compreender a origem social dos signos e o seu papel crucial no desenvolvimento individual (VYGOTSKY, 1991, 43). Diante do croqui de localização de um espaço que vivencia cotidianamente, $\mathbf{M}$ lembra a E, ao mesmo tempo que informa a $\mathbf{A}$, o que the pareceu relevante, o que foi mobilizado a partir de certo ponto de emergência de suas lembranças.

A partir dessa afirmação, conversei com a Coordenadora Pedagógica da Escola. Checamos, ao longo da trajetória de $\mathbf{M}$, se ela havia tido uma atividade que envolvesse especificamente a história de Chapeuzinho Vermelho naquele espaço de convívio. Concluímos que não.

Entretanto, vale lembrar que o espaço da representação (croqui de localização) é destinado, segundo o projeto pedagógico da escola, à organização de atividades simbólicas, como vimos acima. Ali acontecem teatros, brincadeiras simbólicas envolvendo o cotidiano das famílias.

Parece, portanto, que o croqui de localização, nesse momento em que $\mathbf{M}$ narra a história de Chapeuzinho Vermelho, permitiu a ativação de sua memória voluntária e a organização de um conjunto de referências que a fez imaginar, recriar, através da narrativa de elementos de histórias ouvidas, uma nova possibilidade de atribuição de importância e valor àquele espaço.

Proponho, então, um primeiro conjunto de conclusões, baseado na análise desenvolvida até:

- O croqui de localização permitiu a sucessiva reorganização da fala e estabeleceu a linguagem como instrumento de mediação semiótica apropriada à expressão das crianças;

- Evoca, de maneiras diversas, os espaços vividos nesse lugar relevante para a criança;

- Permite, portanto, à criança, a indicação pessoal daquilo que compõe sua espacialidade, seu modo de ver e sentir o lugar. 
Conforme o Capítulo III, apontei que, além da memória natural, há

$$
\begin{aligned}
& \text { [...] um outro tipo de memória mediada que permite ao } \\
& \text { individuo controlar seu próprio comportamento, por } \\
& \text { meio da utilização de instrumentos e signos que } \\
& \text { provoquem a lembrança do conteúdo a ser recuperado, } \\
& \text { de forma deliberada (OLIVEIRA, 1995: 77) }
\end{aligned}
$$

Para M, o croqui, instrumento de mediação nesse momento, ativou aspectos de sua memória que resultaram numa fala que evocou suas experiências, através do espaço figurativo (o croqui de localização), e resultou na narrativa da história do lobo e da floresta. Recorreu ainda a seu parceiro de atividade, para confirmar sua lembrança, embora $\mathbf{E}$ não tenha respondido a essa indicação de $\mathbf{M}$.

Creio que as funções psicológicas que propus como categorias de análise nos servirão agora para compreender o que aconteceu a $\mathbf{M}$ durante sua participação no desenvolvimento dos exercícios realizados. Retomo a reflexão de John-Steiner \& Souberman no pósfacio de Formação Social da Mente:

Ao longo do desenvolvimento das funções superiores - ou seja, ao longo da internalização do processo de conhecimento - os aspectos particulares da existência social humana refletem-se na cognição humana: um individuo tem a capacidade de expressar e compartilhar com os outros membros de seu grupo social o entendimento que ele tem da experiência comum ao grupo (1991: 137)

Realmente, $\mathbf{M}$ demonstrou que, através de um instrumento de mediação, de natureza didático-pedagógica, portanto, pertencente a esfera da cultura escolar, pode compartilhar com A. aspectos relevantes de sua experiência o que, naquele momento, confirmou que o espaço representado trouxera elementos significativos dessa experiência pessoal, diferente do que trouxera E, mas referenciados nos aspectos comuns do compartilhamento das experiências. 
Trata-se de retomar o que vimos em Vygotsky no capítulo anterior quanto à mediação e constatar que, de fato, as crianças demonstraram poder participar ativamente do processo de aprendizado, trazendo elementos das vivências familiares (quando $\mathbf{M}$ menciona o carro para ir a um lugar parecido com a creche), mas, sobretudo, demonstrando que o contexto escolar foi decisivo para que reconstruísse, internamente, informações sobre aquele espaço, representando-o e desempenhando as tarefas propostas.

Mesmo E, cuja inserção na atividade deu-se por alternativas diferentes fixando o foco de sua atenção na câmera, demonstrou níveis de controle sobre sua percepção, atenção e memória, até paralisar as tarefas planejadas e reorganizálas a favor de seu interesse em explorar os equipamentos de filmagem, que acabou focando a atenção de $\mathbf{M}$, quando puderam ver-se dentro da máquina.

Através das narrativas que introduziram na vivência (ver e explorar a câmera), as crianças dirigiram sua atenção a um foco cuja mobilização se deu pela lembrança de $\mathbf{E}$ de que as máquinas registram imagens da realidade. Esse momento criado e conquistado pelas crianças trouxe a elas grande satisfação. Riram, disputaram o visor do equipamento, comentaram sua "presença" no filme, mostraram-se felizes com a novidade. Embora $\mathbf{E}$ tenha selecionado, naquele momento, uma ação de sua preferência, $\mathbf{M}$ participou da novidade com igual entusiasmo. Após certo tempo de manejo da máquina, encerramos a tarefa e passamos para o terceiro exercício, desenvolvido no pátio.

\section{EXERCÍCIO 3}

Neste exercício, as crianças deveriam, então, identificar a surpresa, com a ajuda do croqui. O ambiente é a parte de baixo, antes vista do mezanino. Nos postamos de frente para o ambiente representado.

A - Eu escondi uma surpresa pra vocês aqui, por aqui. Mas, antes, vamos olhar de novo o nosso desenho. Juntos. Vamos olhar mais uma vez o nosso desenho. (apontando a legenda) Olha essa casinha. Será que no nosso desenho tem uma casinha igual a esta (a da legenda)? 
$\mathbf{M}$ - Tem, esta. (aponta a do croqui)

E - (passa os olhos por todo o croqui e não se envolve na atividade. Começa a correr).

A - (aponta para o armário representado na legenda (aberto), continuando a solicitação de que se reconheça no croqui os elementos da legenda)

M - (apontando) É este armário (fechado).

A - Será que esse armário (aponta o armário fechado) é igual a este (o da legenda, aberto)?

M - É este. (aponta corretamente).

A - E este banco (o da legenda)? Onde ele está?

$\mathbf{M}$ - Ete, ete, ete... (aponta todos os representados, um a um).

$\mathbf{M}$ - (aceita participar da atividade, diferentemente de E. Mais que isso, envolve-se na atividade interagindo com A)

Nas situações pedagógicas, pode-se planejar os níveis de mediação semiótica a partir de uma concepção didática das atividades implicadas nesse processo. Entretanto, observo que a mediação enquanto um princípio da ação educativa, vincula-se à qualidade da interação que se estabelece entre os pares envolvidos na situação de aprendizado.

M disponibilizou-se e colaborou para que $\mathbf{A}$ pudesse desempenhar a tarefa a que se propunha, e este é um aspecto relevante. A partir da mediação de $\mathbf{A}, \mathbf{M}$ pôde perceber a relação entre a representação da legenda e os elementos do croqui. Reconhecê-los a partir de sua percepção foi possível pela experiência acumulada de $\mathbf{M}$ na vivência diária no ambiente da escola.

Objetos, eventos e situações atuaram sobre o aparato perceptivo permitindo a M captar os objetos representados, reconhecendo-os a partir de sua experiência, como já vimos.

Creio poder trazer a afirmação do Capítulo III quando discuti, a partir das afirmações de Vygotsky, que há "um estágio de desenvolvimento intermediário 
entre o processo elementar e o completamente instrumental" (VYGOTSKY, 1991: 54). As crianças $\mathbf{E}$ e $\mathbf{M}$ demonstraram que, em função de aprendizados anteriores os instrumentos têm, para cada uma, funções diferentes. Reconheço que cada criança fez uma trajetória pessoal diferenciada e é este dado que deve ser levado em conta quando se planeja e decide sobre o trabalho pedagógico na Educação Infantil.

A representação gráfica, aqui, é compreendida como um instrumento que favorece a inserção da criança em atividades planejadas que resultem na mobilização de suas capacidades no âmbito das relações sócio-espaciais, revelando seu potencial como recurso pedagógico essencial ao trabalho envolvendo o lugar e suas paisagens.

Concomitantemente a mediação entre A e M, E está correndo pelo pátio e, repentinamente, entra numa das casinhas, e exclama vendo algo (apanha a caixa de bombons que estava fixada a um dos cantos com fita adesiva). Defendo que $\mathbf{E}$, tendo se convencido de que havia algo interessante envolvido naquela atividade, buscou encontrar indícios desse elemento surpresa. Circulou pelo pátio livremente (para o desconforto dos educadores que esperavam de A uma atitude de repreensão à criança). Não o fiz, pois sabia que, inquieto, E havia captado um sentido mais geral da situação quando chegamos ao pátio e eu Ihes disse que havia ali uma surpresa escondida.

Embora a atitude de $\mathbf{E}$ pudesse não ser a prevista, acabou criando a oportunidade de se reconhecer a capacidade de orientação pessoal que cada criança conquista com sua inserção em atividades práticas. O que me chamou a atenção na atitude de $\mathbf{E}$ é que encontrou sua caixa de bombom. Cumpriu sua tarefa. A princípio imaginei estar diante de uma atitude aleatória. Mas refletindo e analisando a questão parece que se está diante de outra possibilidade de interpretação do fato.

Neste caso, sem recorrer ao croqui diretamente (mas também após examiná-lo juntamente com $\mathbf{M}$ e A), sai correndo pelo pátio e para repentinamente quando avista algo novo dentro da casinha. É necessário esclarecer que E é muito 
pequeno e de onde se postou no pátio, ganhou um campo de visão que permitia avistar um pequeno pedaço de fita adesiva, pendendo do lugar onde estava a surpresa.

A importância da solução oferecida por E está no fato de se demonstrar que em situações mediadas as crianças são capazes de interagir e construir suas experiências participando dessas atividades, levantando hipóteses, após observar e analisar as situações nas quais possam estar envolvidos.

A presença de $\mathbf{E}$ faz esse desafio. Uma criança de três anos, atuando em atividade planejada, no contexto escolar, num espaço delimitado, interagindo com uma parceira e um adulto, mediadores no desenvolvimento dessa atividade, formando o que Rogoff (1990) denominou de "cenário interativo", em atividade com objetivos e orientadas tornando-se uma unidade de análise de processos de participação.

E desempenhou a atividade e alcançou um resultado satisfatório. Este fato não pode ser considerado irrelevante por contrariar as hipóteses iniciais. Não posso propor qualquer aspecto relativo a criação de algo na ZDP de $\mathbf{E}$ que sustentasse a idéia de que teria ocorrido o aprendizado envolvendo uso de croquis. Nem era essa a finalidade da atividade. Mas é possível identificar que, desafiado, E construiu estratégias de participação e desempenhou um papel importante na atividade. É importante para o âmbito do trabalho didático envolvendo as representações gráficas e o que possibilitam.

Seu comportamento inquieto, porém, gerou a reação de outros adultos, que de longe, apoiavam a atividade. Quando E arrancou a caixa de bombons do lugar, a reação do Sr. R., (o vigia que acompanhava a atividade de longe) foi a de ralhar com o menino. Realmente, observando de fora as atitudes de E e M uma pareceria adequada e a outra inadequada. A decisão de conduzir $\mathbf{E}$ de volta a sua turma, envolveu justamente esse contexto escolar.

Ao retornar para perto de $\mathbf{A}$. com a caixa de bombom em mãos, $\mathbf{E}$ foi contido por Sr. R. que tinha a intenção de ajudar a situar o menino na atividade que se 
passava entre A e $\mathbf{M}$. Estando de posse de sua surpresa não fazia mais sentido manter E conosco. Ele estava ansioso por levar sua surpresa para a professora. E assim foi feito.

Retomando a atividade com $\mathbf{M}$, volto a descrever a seqüência do exercício.

A - M, (apontando para a legenda) você me disse que esta casinha (da legenda) é igual a esta (do croqui) este armário (legenda) igual a este (croqui) e este banco (legenda) igual a estes todos (croqui).

M - (explora os elementos pictóricos ligando-os com uma linha imaginária feita com o dedo indicador)

A - (acrescenta um X vermelho no ponto de saída (legenda) e outro no de chegada (croqui), em cada um dos elementos)

(Depois de $\mathbf{M}$ explorar cada um dos elementos e demonstrar que havia se apropriado da noção do conjunto figurativo que o croqui representava, concluímos uma parte do exercício).

Seguramente o que se passou com $\mathbf{M}$ nesse momento foi uma interação entre suas possibilidades de aprendizado em favor de seu processo de desenvolvimento. Retomando Vygotsky, fica claro como os processos de desenvolvimento estimulados pelo aprendizado escolar são essenciais para revelar a rede interna e subterrânea de desenvolvimento de escolares (1991: 54). M demonstrou perceber a finalidade do croqui em diversos momentos, mas pôde transformar sua percepção em gesto indicativo de sua compreensão, quando apontou sucessivamente e, cada vez mais, sem hesitar, da relação entre os elementos da legenda e a representação gráfica.

A - M, eu guardei uma surpresa pra você num dos lugares que estão marcados com a cruzinha. Você quer procurar? Você quer levar o papel? M - (sem dizer nada, levanta-se) Olha por todo o pátio. Volta a olhar para o croqui. Hesita. 
Aqui ficou claro que $\mathbf{M}$ decidira colaborar com a atividade porque seu processo pessoal de atenção foi implicado na atividade. Enquanto $\mathbf{E}$ desenvolvia sua atividade de acordo com suas possibilidades, $\mathbf{M}$ não abandonou o lugar que escolhemos para observar e conversar sobre o croqui.

Não deixou de manejá-lo nem mesmo quando $\mathbf{A}$ foi ao encontro de $\mathbf{E}$. M permaneceu trabalhando com seu dedinho indicador sobre a legenda e os elementos do conjunto figurativo, demonstrando interesse num foco de sua escolha, de maneira voluntária, que era o armário.

M observou o pátio antes de procurar sua surpresa. Poderia escolher entre duas possibilidades. Chamo a atenção para esse momento extremamente pessoal, em que se observa uma atividade interna intensa da menina quando ela fica em pé, olha para os lados, balançando o corpo (direita e esquerda, girando sobre os pés) e sai resoluta em direção ao armário. A seqüência que segue foi feita em silêncio.

M - (dirigiu-se até o armário, diante do armário, parou. Torceu as mãos, uma na outra. Pendeu o corpo para a direita tirando o pé esquerdo do chão. Abaixou-se. Manteve-se absorvida pela busca de sua surpresa. Abaixada, explorou a prateleira rente ao chão. Nada encontrando, levantouse. Com as mãos no ar, flexionadas, passou os olhos pelos objetos dessa segunda prateleira, ao seu alcance. Esticou o braço. Nada encontrou em uma caixa fechada, da qual levantou a tampa. Afastou-se e continuou olhando. Ergueu a cabeça para as prateleiras mais altas. Desceu os olhos e voltou a se concentrar na prateleira diante de si. Sem esticar as mãos, espiou para dentro de uma caixa sem tampa, dentro estava encaixada a caixa de bombons, um pouco menor. Tendo reconhecido a embalagem retirou a surpresa do esconderijo e mostrou para $\mathbf{A}$ )

A - Como você descobriu que estava lá?

M - O E já foi.

A - Esta caixa de bombom é pra você comer junto com seus amigos e sua professora e eu fiquei muito feliz de você me ajudar a organizar essa brincadeira, com esse desenho. Você gostou de brincar? 
M - (afirma com a cabeça, mas, emocionada, não diz nada. As lágrimas escorrem).

A - Você está triste?

M - (recompondo-se) Vou comer bombom. (conduzimo-nos ao andar de cima)

M demonstrou ter estabelecido relações dinâmicas a partir da introdução do croqui de localização como mediador da situação que precisava resolver. Explorou todas as possibilidades de interpretação daquela representação gráfica quando, usando a linguagem, narrou todos os elementos que foi encontrando. Depois, incorporou a legenda como elemento mediador para a interpretação definitiva do croqui, o que colaborou para a resolução da situação apresentada.

Ao invés de definir um único elemento-surpresa e, portanto, uma única referência na legenda, defini dois elementos-surpresa. $\mathbf{E}$ resolveu a situação de forma concreta, de forma coerente com suas experiências. A atitude de $\mathbf{E}$ fez com que $\mathbf{M}$, observando a cena, decidisse não procurar na casinha em que $\mathbf{E}$ havia encontrado sua caixa.

Sua hipótese recaiu sobre o armário. Sua busca revelou uma forma planejada de solução para a questão. Investigou a prateleira rente ao chão. Depois ocupou-se da segunda prateleira a seu alcance. Não encontrando nada olhou para as prateleiras de cima. Com esse gesto parece ter levantado a hipótese de a surpresa estar fora de seu alcance.

Vamos lembrar que Vygotsky indica "o aprendizado é um aspecto necessário e universal do processo de desenvolvimento das funções psicológicas culturalmente organizadas e especificamente humanas". (1991: 101), uma vez que há funções que as crianças só podem por em ação sob orientação, em grupos, e em colaboração umas com as outras, porque não as dominaram de forma independente.

Além disso, se lembrarmos que, segundo Vygotsky, não há identidade entre os processos de aprendizado e de desenvolvimento interno, a experiência de $\mathbf{M}$ 
parece mostrar que esse processo ocorreu quando ela registrou o episódio de E e, por iniciativa própria, decidiu buscar sua surpresa no armário que localizara, anteriormente, ao interpretar a legenda do croqui. Toda esta atividade releva o papel da mediação como eixo didático nas práticas pedagógicas destinadas à Educação Infantil.

\section{Atividade B}

\section{EXERCÍCIO 1}

O croqui de localização é oferecido a $\mathbf{R}$ e $\mathbf{W}$, respectivamente, 5 e 6 anos.

A - Oi, meninos. A professora disse que a gente ia fazer uma atividade legal?

W e $\mathbf{R}$ - (acenam a cabeça afirmando)

A - Então, é que eu fiz um desenho e eu estou perguntando pras pessoas se está bom. Eu perguntei pra Sandra e ela me disse que vocês poderiam ajudar. É esse aí.

W - É ali onde a gente fica (levanta o braço buscando uma direção, e aponta para o alto, e conversando com R).

$\mathbf{R}$ - Ó o banco.

W - Olha o parque (o parque não está visível)

A - Eu não vi o parque...

W - Sai aqui (aponta o dedo para a porta e vai fazendo um trajeto imaginário explicando o que tem lá fora. No croqui esta situação se esclarece observando-se a porta aberta do lado esquerdo, ao lado da casinha de telhado vermelho)

$\mathbf{R}$ - É aqui, assim (também batendo sobre a porta). Tem a casinha.

A - Mas a casinha não é esta? (apontando para a casa perto da porta).

R - Não, a outra, de lá (de fato há uma outra casa na área externa). 
Nesta dupla, fica evidenciado que as funções superiores já compõem processos mais desenvolvidos, na medida em que relacionaram prontamente a representação ao espaço concreto. W apontou, no conjunto figurativo, que o reconhecia como o lugar onde ficam. Refere-se ao espaço todo. $E$ inclui o parque da área externa.

Aqui a linguagem assume papel preponderante. A mediação criança-criança se desenvolve primeiramente. Dialogam e introduzem A na conversa respondendo a ela. Pode-se inferir, da fala de $\mathbf{W}$ que o ensino que consistiu sua experiência escolar até ali, colaborou para que pudesse ler e interpretar aquele croqui de localização sem a necessidade de mediação de qualquer outro par. W demonstrou capacidade de colaborar com o par menos maduro, demonstrando independência em seu desenvolvimento. $\mathbf{R}$ necessitou da colaboração de W para, através da interação, construir referências que permitiriam que viesse a atuar segundo a proposta de atividade.

Creio que a hipótese da colaboração dos croquis de localização como instrumentos adequados à mediação, observação, análise e síntese, se confirmam com essa atitude de $\mathbf{W}$.

Fica evidente que o uso do croqui ao organizar atividades destinadas a espacialização, favoreceu a interpretação da criança do espaço de sua vivência diária, sem qualquer mediação. Para $\mathbf{R}$ foi decisivo a mediação de $\mathbf{W}$ para interpretar o croqui, segundo sua experiência.

As crianças inferiram a área externa da escola, pela mediação da porta aberta. Ao comparar as situações conhecidas e representadas, e considerando sua experiência de locomoção puderam localizar outros elementos ausentes da representação.

Juntos, $\mathbf{W}$, como parceiro mais experiente, colaborou para que interpretassem o croqui, articulando os elementos pictóricos representados e indicando os elementos que estavam fora da representação, no parque, ao qual se chega pela porta aberta representada no croqui. 
As duas crianças, em diálogo, utilizando os croquis, puderam estabelecer consensos sobre aquela representação, não surgindo, dessas falas, focos diferenciados de atenção, como vimos entre as crianças menores.

$\mathbf{W}-\mathbf{R}$, olha a mesa...e a torneira.

$\mathbf{R}-\mathrm{O}$ banco é bonito.

A - você já se sentou num banco assim?

$\mathbf{R}$ - É. Lá tem um monte (fica encantado com a representação do banco)

W - E tem esse armário (representado a direita, aberto com prateleiras)

A - Você conhece esse armário?

W - Conheço, tem na casa da minha vó...

A - É esse armário ou é parecido com esse?

W - Esse é de lá de baixo. O da minha vó ta na casa dela.

Outra questão relevante, aqui, é que mais uma vez A na tentativa de dar pistas para a interpretação, pergunta se conhecem algum armário aberto, que havia chamado a atenção dos meninos. Como não havia dúvida que a representação era do armário da escola, $\mathbf{W}$ interpretou que $\mathbf{A}$ falava de outro armário e não o da representação ou o do pátio. Neste caso a mediação não foi adequada. Não houve sensibilidade para se perceber que a criança já conhecia o armário, fosse na representação, fosse na realidade e foi capaz de correlacionar as duas dimensões.

Também se revela, através da mediação criança-criança, que no desenvolvimento destas há um ponto de viragem mesmo quando ocorrem aparentes descontinuidades.

Ao longo da atividade $\mathbf{W}$ parece "saber mais" que $\mathbf{R}$. A interpretação de $\mathbf{R}$ das informações ali organizadas depende mesmo da mediação de $\mathbf{W}$. Entretanto $o$ que se observa é que $\mathbf{R}$ exemplifica com suas elaborações, como decorrência da mediação de $\mathbf{W}$, uma aproximação com $\mathbf{M}$ da dupla anterior. 
Assim como ela, $\mathbf{R}$ usa o recurso de apontar para elaborar sua interpretação dos elementos figurativos. Apontar - neste caso sobre o signo da representação destacando os bancos, a porta e o parque fora -, conforme vimos no capítulo anterior, tem importância essencial no processo intrapsíquico da criança, já que ela aprendeu, de forma reiterada, que quando aponta alguém intervém para esclarecer aspectos de sua interpretação. $E$ isto esteve presente na interação W-R. Quando R apontava, W reiterava ou corrigia suas observações.

E é isso que se vê ao longo do diálogo. A mediação acabou trazendo, através do croqui, o parque. A criança aproximou-se de algo que é relevante em sua experiência. Apontar, neste caso, teve o mesmo sentido que na experiência das crianças muito pequenas, conforme Vygotsky, ao apontar para alcançar o objeto de seu interesse.

Como atividade do processo ensino-aprendizado, esse tipo de atuação da criança pequena é decisivo para o desenvolvimento. A uma intervenção deste tipo poderá seguir-se a organização de um amplo conjunto de informações, hipóteses, perguntas etc. por iniciativa da criança e é isto que conduz aos pontos de viragem.

A interação entre as crianças revela que o croqui de localização, enquanto instrumento de mediação, organiza as referências históricas e culturais contidas na organização dos espaços da escola e ali representadas. Os croquis de localização introduzem as noções das espacialidades diferenciais, conforme propostas por Lacoste ${ }^{48}$, organizam e sistematizam as informações e dados que permitem conhecer o espaço.

Quanto menores forem as crianças, mais suas representações e noções sobre o mundo estão associadas diretamente aos objetos concretos da realidade conhecida, observada, sentida e vivenciada. O crescente domínio e uso da

\footnotetext{
${ }^{48}$ Conforme conceito apresentado no capítulo II.
} 
linguagem, assim como a capacidade de interação possibilitam, todavia, que seu contato com o mundo se amplie, sendo cada vez mais mediado por representações e por significados construídos culturalmente. (VYGOTSKY, 1991)

Nesta dupla falar e pensar constituiu um processo de significação que envolveu ampliar o espaço da representação para o espaço do parque. Embora o parque não estivesse presente na representação foi possível pela interação entre as duas crianças introduzir esse lugar na mediação. Pino propõe:

Significar, ou seja, estabelecer relações possíveis entre sinais e coisas ou eventos, é característica fundamental de ser humano e condição/efeito da emergência da consciência. (1994: 10).

Através de seu enunciado as crianças trouxeram a informação do acesso representado (porta aberta) para o parque, indicando aí um caminho a ser investigado, para o trabalho didático, envolvendo o trabalho com os croquis e o desenvolvimento do raciocínio geográfico.

Em outra passagem quando juntas vão localizando a mesa, as torneiras e os bancos indicam um mesmo foco de atenção, algo que ocorreu de forma diferenciada com a dupla anterior. $\mathbf{W}$ e $\mathbf{R}$ trazem uma experiência que já permite identificar o representado por sua condição intrínseca. As crianças menores começaram sua interpretação da representação, mencionando a comida e o ato de lavar as mãos, evocando as atividades desenvolvidas no espaço.

Na segunda dupla a experiência escolar permitiu a descrição dos objetos chamando-os pelos nomes com os quais são identificados. Através da linguagem as crianças mediaram seu conhecimento estabelecendo um processo comunicativo socialmente relevante. 
Há ainda um aspecto relevante, que trago do Capítulo II, e que diz respeito a coerência entre as palavras e os atos educativos. A inferência que as crianças fizeram da presença do parque, mediada pela porta aberta, indica que as interconexões que estabeleceram com o ambiente foi proporcionado pela coerência do projeto pedagógico que vimos na caracterização da escola.

Não só o pátio interno é destinado a atividades simbólicas. De forma sistemática o parque também é utilizado para atividades sistematizadas, diariamente, a partir das diretrizes dos planos que apresentamos anteriormente. As crianças demonstram conhecer o ambiente e os espaços de sua escola, o lugar em que vivem o seu dia-a-dia. As crianças mobilizaram esse conhecimento para interpretar o croqui.

Demonstraram através da interação com o adulto e entre si uma inserção na vida da escola. As formas comunicativas revelam as condições subjetivas presentes, no caso das quatro crianças, considerando-se que cada uma interviu nos exercícios de forma autônoma. Essa subjetividade se expressa também nas condições pessoais quanto à idade, características individuais, capacidades, interesses, exigências e outras atitudes perante cada exercício da atividade.

É relevante que as crianças, das duas duplas, tenham demonstrado capacidade de desenvolver atividade autônoma demonstrando independência, envolvendo-se nos exercícios até alcançar a solução do problema.

Voltando a Kostiuk é importante ressalvar, como ele o faz, que "a educação que separa as palavras dos atos é um fracasso" (1991: 33). O trabalho com o croqui valoriza as experiências no espaço vivido. Desafia a criança a perceber sua posição no coletivo. Remete e evoca as experiências ao alimentar-se, ao brincar, nos processos de higiene, nas atividades planejadas, nas interações com adultos e crianças. Isto traz a coerência que Kostiuk propõe e é o que está presente nas atitudes da dupla mais velha, quando se evidenciam os resultados inclusivos do processo educativo. 
Chama a atenção que as crianças desta dupla, tal qual proposto por Kostiuk (1991: 33), tenham estabelecido interconexões tão evidentes com o ambiente, demonstrando-o através da fala, dos enunciados sobre a existência do parque, mediados pela representação da porta aberta, como se pode constatar na Figura 2 (p. 136).

Essa possibilidade de atuação das duas crianças é o resultado do trabalho pedagógico, que Vygotsky, e depois os pesquisadores que tomaram suas pesquisas como parâmetros, propuseram como decisivos no processo formativo da criança.

Observo que cada uma delas demonstrou uma vivência real naquele espaço. A escola representou a oportunidade para que construíssem vivências reais, incluindo as condições subjetivas, já que só assim crianças são capazes de atuar. Estas crianças atuaram de acordo com as condições de seu desenvolvimento, sua idade, capacidades, interesses. Estes são ganhos possíveis a partir de um processo educativo formal, que tome a criança como sujeito educativo. A conduta de $\mathbf{W}$ e $\mathbf{R}$, a atitude autônoma, a qualidade do processo comunicativo, demonstraram que são crianças, cuja infância, em termos de escola, está protegida.

Não que as dificuldades não sejam evidentes. São crianças que pertencem a uma classe social excluída, lidam com profundas restrições socioeconômicas, enfrentam problemas familiares próprios desse tipo de contexto. Ocorre que, neste caso, a Escola tem respondido a cada uma delas de forma a valorizar a presença de cada uma por força da diretriz que busca fazer permanecer toda criança na escola.

Esse conjunto de reflexões ajuda a compreender o porque de essa dupla não ter sentido necessidade de desenvolver o que chamei de exercício 2. Sua experiência escolar mais sistematizada, Fase II e Fase III, levaram a constatação de que o croqui era a representação do pátio, já no exercício 1. Mesmo distantes do pátio, fechados na sala dos professores, dialogaram sobre as características desses espaços vividos. 
$\mathrm{Na}$ verdade essa dupla demonstrou, ao sairmos da sala dos professores um interesse objetivo por encontrar sua surpresa. Sua atenção tinha um foco e tomaram a iniciativa de organizar sua atuação objetivando resolver a situação que trazia uma surpresa como desfecho.

Na medida em que o croqui (instrumento de análise e localização referente a relações sócio espaciais) favorece a observação, a organização de informações, a análise e a localização, compondo assim uma base para o desenvolvimento do raciocínio geográfico, o que irá contribuir para o processo de abstração, podemos dizer, lembrando aqui Leontiev (1988), que assim, o pensamento abstrato se fortalece pela vida social organizada e estável, o que a escola garante com muita qualidade, quando trabalha valores e princípios de compromisso com a formação da infância e juventude objetivando sua autonomia e atuação cidadã.

Aqui é importante lembrar Ratner (1995) quando afirma que as operações cognitivas também são determinadas culturalmente. Exemplifica apontando os padrões monetários na aprendizagem e as operações matemáticas na lavoura. Essa ponderação de Ratner faz refletir sobre os riscos de se contextualizar o ensino para as crianças a partir de uma matriz de pensamento que se baseia no status quo, com foco nas concepções docentes e dos adultos.

Os croquis podem garantir a inclusão de interpretações originais que as crianças trazem, em momentos de evocação, através da memória, independente das seqüências didáticas, dos espaços vividos, que possibilita o desenvolvimento individual num contexto significativo, portanto referente ao coletivo e ao papel do sujeito, aí inserido.

Chamo a atenção sobre esse aspecto porque as crianças, a partir de sua experiência escolar, demonstraram não ser necessário desenvolver o exercício 2. A supressão dessa etapa é relativa a deliberação que puderam provocar a partir de sua interpretação. Enquanto instrumentos, os croquis estimularam a finalidade e a intencionalidade (Ratner, 1995:46) na ação das crianças, em buscar resolver a situação problema, que guardava o elemento surpresa. 


\section{EXERCÍCIO 3}

A representação oferecida às crianças maiores suprimiu detalhes pictóricos, constantes do croqui oferecido a crianças menores. Foram mantidas as variáveis de cores. Os elementos foram apresentados por suas formas esquemáticas, conforme a Figura 2 (p. 136).

Novamente, foi feita a orientação sobre as surpresas e as marcas da legenda. A legenda, entretanto, já estava representada. Havia três elementos na legenda, mas apenas duas marcas sinalizando os locais da surpresa, a partir da legenda, através de bandeirolas. A partir daí as crianças se detiveram:

W - (observa atentamente a representação). Eu sei onde tá a surpresa. (Levanta-se e vai em direção à casinha, onde encontra a caixa de bombons).

A - Mas ainda falta uma.

(W e F observam a representação)

A - Onde será que está a outra surpresa?

W - Tá no banco.

A - Por que você acha que está no banco?

W - Porque aqui (mostra a legenda) a bandeirinha está no banco.

$\mathbf{R}$ - Eu vou achar. (sai em direção aos bancos)

R e W - (ambos tomam distância do banco, olham o conjunto de frente. Examinam por cima e, depois, abaixam-se e procuram sob os vários bancos. Não encontrando, dirigem-se a um banco isolado do outro lado. Repetem a mesma operação. Procuraram em cima e embaixo dos bancos, pois sabem que as caixas estavam fixadas com fita. Voltam para o conjunto maior de bancos coloridos. W, gentilmente, dá espaço para o amigo que precisa achar a "própria" caixa de bombom. Dirigem-se a A).

A - Já procuraram em todos os lugares?

W e F - Já. 
A - Que lados vocês procuraram?

W e $\mathbf{R}$ - Em cima (apontam sobre o banco), embaixo (apontam a parte de baixo).

A - E o banco só tem esses dois lados?

W - (imediatamente percebe que pode estar do lado de trás e sai observando as costas de todos os bancos)

$\mathbf{R}$ - (observando o movimento do colega mais velho, sai em busca do pacote atrás dos bancos).

W e $\mathbf{R}$ - (encontram simultaneamente a caixa de bombom. Afastam o banco e pegam-na).

Esta tarefa, finalmente, confirma a hipótese de que o croqui de localização é um instrumento de mediação pertinente para o desenvolvimento de noções e raciocínio geográfico na Educação Infantil.

As crianças demonstraram poder orientar-se, utilizando-se de um croqui. Construíram hipóteses. $\mathbf{W}$ interpretando a legenda prontamente entendeu que a caixa de bombons estava na casinha, conforme Figura 2. Aí a mediação se deu pelo instrumento e creio que já aprofundamos a discussão o suficiente para compreender que as experiências das crianças permitem esse grau de autonomia, considerando o caso peculiar de cada uma.

Para $\mathbf{R}$, esse momento de atuação de $\mathbf{W}$ foi acompanhado por observação. $\mathbf{O}$ que ocorre a seguir exemplifica uma outra possibilidade de mediação, criançacriança. Observando o croqui, $\mathbf{W}$ conclui que a outra caixa de bombom estava no banco. Em parceria, em efetiva colaboração (W assume atitude de ajuda abrindo espaço para a observação de R) Entretanto, o grau de dificuldade no exercício faz a dupla retornar até $\mathbf{A}$.

Aí ocorre, então, o terceiro tipo de mediação na atividade, criança-adulto. Uma simples indagação desencadeou o processo de interpretação de $\mathbf{W}$, seguido prontamente por $\mathbf{R}$ que é o primeiro a avistar a caixa, presa às costas do banco. Em colaboração, ambos afastam o banco e retiram a caixa. 
Sobretudo na exploração do banco, como elemento mediador da surpresa, examinaram os aspectos que pareciam ser corretos para a localização da surpresa. A mediação do adulto colaborou para que $\mathbf{W}$ pudesse concluir que a surpresa estava no lado de trás do banco.

Podemos então distinguir o papel do croqui de localização para a primeira dupla e para a segunda. Para as crianças menores vimos que o croqui, neste caso, é um importante instrumento para ativar as funções psicológicas superiores, desafiando as crianças a buscar, através da fala, possibilidades de interpretação para a representação gráfica.

O papel dos croquis de localização para as crianças maiores vincula-se ao trabalho de construção do conhecimento geográfico, constituindo um discurso gráfico (Biaggi, 2000). Observa-se que as crianças testaram suas hipóteses, sintetizando, no âmbito dos exercícios propostos, no momento dessas interpretações. De forma simples, mas não simplista, as crianças buscaram compreender a atividade proposta, resolvendo-a.

No caso das crianças menores, os objetivos foram alcançados e algo mais pode ser incorporado. No caso de $\mathbf{E}$ foi possível compreender seu nível de engajamento na atividade, desmistificando a idéia de que a criança pequena não teria condições de desempenhar a atividade. Particularmente valorizo o fato de $\mathbf{E}$ ter realizado sua tarefa, mesmo que de forma questionável ou polêmica. Penso que $\mathbf{E}$ deixa um desafio para que se proceda 0 aprofundamento de outros estudos dessa natureza, a partir de seu caso.

Para as crianças mais velhas os croquis confirmaram as hipóteses levantadas. A primeira que é pertinente introduzir as representações gráficas como conceito/ conteúdo nas matrizes curriculares dos eixos já discutidos, através da Geografia.

A segunda hipótese confirmada é que as linguagens comunicativas envolvidas na leitura e interpretação de mapas são essenciais a construção do raciocínio geográfico desde a Educação Infantil, exatamente porque podem ser compreendidos como importantes instrumentos semióticos, em condições de 
compor as atividades planejadas. Assim um segundo conjunto de objetivos é atingido ao ativar as funções psicológicas superiores como a percepção, atenção e a memória, garantindo os processos de internalização dessas funções o que resulta na criação da zona de desenvolvimento proximal, sempre a partir da mediação docente. Naturalmente este estudo não demonstrou a criação efetiva dessa zona de desenvolvimento proximal. Mas ficou claro que a articulação das funções psicológicas superiores envolvidas na situação analisada aponta nessa direção.

Do comportamento das crianças desta dupla foi possível inferir a importância que atribuíram ao fato de poder dominar aquela situação. Demonstraram compromisso quando, após a mediação, decidiram procurar a última caixa de bombons. Esse sentimento de domínio sobre as coisas marca a possibilidade de as crianças desenvolverem as experiências de autonomia.

Outro aspecto relevante é que as crianças podem apreender do uso de croquis, que instrumentos podem servir a seus usuários, o que também marca os processos de construção da autonomia. E essa autonomia pode se consolidar na medida em que o uso de instrumentos como os croquis incitam ao pensamento abstrato, como demonstrou $\mathbf{W}$ ao responder com uma firme atitude a indagação de A sobre se um banco tem apenas os lados de baixo e de cima. Sem proferir palavra, imediatamente, identificou o lado de trás (as costas do banco).

Imitando W, R envolveu-se na construção de estratégias que levassem a solução do problema: localizar a ultima caixa de bombons. Além de ficar evidente níveis de abstração nas atividades intrapsíquicas de $\mathbf{W}$, sua atitude estimulou a imitação em $\mathbf{R}$, o que comprova a proposição de Vygotsky que a imitação é um poderoso processo de aprendizagem nas crianças pequenas.

As crianças demonstram estar em condições de estabelecer relações distantes através do croqui. Movimentaram-se por todo o espaço do pátio, seguindo a indicação da legenda do croqui. Havia mais de um conjunto de bancos espalhados pelo espaço. As crianças procuraram em todos. Não somente no conjunto em que comumente desenvolvem as atividades simbólicas. 
A necessidade de resolver a situação para $\mathbf{R}$, já que $\mathbf{W}$ resolveu prontamente sua parte, fez com que as crianças estabelecessem uma meta e se ajudassem na solução da questão. O problema foi contextualizado espacialmente, o que era uma das finalidades da atividade. As crianças sabiam que a solução estava circunscrita aos bancos coloridos. Isto significa a oportunidade de categorizar o problema. O objetivo da atividade é atingido quando as crianças localizam a ultima caixa de bombons.

Portanto o impacto no uso dos croquis de localização, com crianças pequenas, na Educação Infantil, estimula o pensamento representativo e a imaginação. Esses produtos representativos podem estabelecer modelos para 0 pensamento simbólico. Isto torna o croqui em instrumento significativo. Pode construir a possibilidade de transformar-se em instrumento de mediação que favorece a deliberação sobre o uso e atuação no âmbito do lugar, dos espaços vividos. A quantidade de informação que o croqui permite não estaria presente nas situações de ensino e aprendizagem, se dependessem exclusivamente de outras linguagens não destinadas a representação espacial.

O trabalho com as representações gráficas é pertinente como: 1 - material escolar adequado, 2 - instrumento de mediação capaz de favorecer o processo pedagógico, na medida em que é portador dos conteúdos, relações e práticas sociais através de signos próprios da linguagem que utiliza, 3 - enquanto conteúdo e conhecimento escolar apropriado ao processo formativo. 


\section{CONCLUSÕES FINAIS}

Ao longo do trabalho propus uma reflexão sobre os fundamentos teóricos que ajudassem a pensar em que medida representações gráficas - mais especificamente os croquis de localização - poderiam representar contribuição efetiva do campo da Geografia para o campo emergente de uma Geografia não escolarizada segundo os parâmetros do ensino fundamental, mas de acordo com as necessidades de constituição de um campo didático, organizado por eixos temáticos, na Educação Infantil.

Para delimitar o estudo de caso, base do trabalho, optei por trabalhar o eixo Natureza e Sociedade e a partir daí construí a atividade de campo. Ao partir das proposições do eixo temático dos Referenciais Curriculares da Educação Infantil, assegurei uma aproximação com a realidade das Instituições de Ensino e isso foi relevante para compreender o trabalho pedagógico da Escola em que o Estudo foi desenvolvido.

O projeto pedagógico da Escola Serraria indicou a importância do trabalho sistematizado para consolidar a proposta educacional da escola. A equipe da escola fez opções metodológicas e didáticas que foram baseadas, inclusive, nesses documentos oficiais. Políticas públicas como essa, colaboram para a construção de identidade dos níveis de ensino propostos a propósito da consolidação do Sistema de Ensino que estrutura a Educação Básica.

Essa estrutura e suas regras de funcionamento são fundamentalmente responsáveis pela possibilidade efetiva de se assegurar o direito de acesso a educação. Examinando as opções de gestão da Escola Serraria observa-se que os eixos temáticos propostos pela escola decorrem do RCNEI. Todavia, a escola amplia sua ação educativa e incorpora as diretrizes do Sistema Municipal de Ensino. Como vimos, a cidade construiu uma experiência de gestão popular e trabalha com a perspectiva da permanência da criança na escola. 
Aí, onde os direitos são de fato apropriados, as relações socioespaciais são decisivas para a organização da vida das pessoas e, sobretudo, para sua participação. Não poderia haver melhor experiência educativa para instigar ao questionamento acerca da importância das cartas na formação dos cidadãos. Este estudo demonstra que cada instituição de ensino tem a possibilidade de construir o seu acervo de cartas e transformar esse acervo num conjunto de natureza didática.

Ainda que cada escola e cada sistema de ensino estejam marcados por suas características, identidades, peculiaridades, a possibilidade de haver referências curriculares construídas desde as práticas das instituições e os resultados da pesquisa científica/acadêmica em amplo debate é que garante a oportunidade de se formar as crianças e a juventude a partir de valores e princípios da cidadania que só a Educação e a escola podem assegurar.

A crítica às ações de implementação das políticas públicas, no caso deste estudo, o RCNEI, alerta para o risco prescritivo desses documentos. Entretanto, as políticas devem ser reivindicadas e asseguradas em todos os níveis da educação. A própria crítica é a garantia de que não haja imposição de diretrizes que desrespeite as características do sistema, localmente, onde a Educação acontece.

Outro aspecto relevante que o estudo apontou foi a possibilidade de se delimitar esferas e eixos temáticos relevantes, pertinentes e significativos decorrentes da Geografia enquanto um campo do saber formal, através de aproximação entre os ganhos consolidados pela Geografia Escolar e a construção de uma didática apropriada a Educação Infantil envolvendo o ensino fundamentado no campo científico.

As representações gráficas mostraram-se adequadas para a introdução de conteúdos que permitem a organização de atividades de espacialização. Através dos croquis de localização as crianças explicitaram sua interpretação do espaço representado, apontando posições de objetos através de um vocabulário próprio, construído a partir de sua experiência. 
Os croquis são excelentes instrumentos para se introduzir a bidimensionalidade através da representação. Além disto o que a atividade proposta para o estudo de caso possibilitou foi o deslocamento das crianças de forma planejada, a partir de sua interpretação, indo de um ponto a outro e resolvendo a situação problema.

Fica demonstrado que os croquis de localização são instrumentos ideais para a organização de atividades que introduzam as experiências destinadas a aprofundar as relações socioespaciais. Favorecem a descrição do espaço representado além de favorecer a identificação de pontos de referência para pequenos trajetos, como proposto no RCNEI.

No caso do estudo em análise, a dupla de crianças de 5 e 6 anos, experimentaram diversos trajetos entre os pontos em que deveriam estar escondidas as surpresas. Utilizando-se da legenda do croqui e da mediação com o pesquisador, fizeram percursos diversos, orientados, e puderam encontrar sua surpresa.

Também as crianças pequenas passaram por essa experiência. Cada uma delas, entretanto, de acordo com suas possibilidades. A criança de 3 anos não chegou a orientar-se por pontos de referência. Mas, a partir da mediação com o pesquisador, explorou concretamente o espaço que observara e identificara através do croqui e soube que encontrara a surpresa mencionada quando observou algo diferente na casinha em que estava a caixa de bombons.

Uma conclusão importante para a perspectiva que aqui adotei é que a solução tem papel preponderante na condução de uma atividade, sobretudo quando a criança sente-se envolvida em sua construção. O trabalho de mediação possibilitado pelo instrumento croqui demonstrou favorecer esse tipo de construção pela qualidade que acrescenta a mediação que se estabelece entre criança-criança e criança-adulto.

É importante assinalar que, no RCNEl, a chamada estruturação do espaço é tratada como questão pertinente ao campo da Matemática. Na realidade a 
insuficiência do debate em torno das questões do ensino escolar é que provoca tal encaminhamento. Sem prescindir da linguagem matemática, portanto adotando uma perspectiva interdisciplinar, está claro que as representações gráficas do campo da Geografia são essenciais para a efetiva organização de atividades que favoreçam a construção das relações socioespaciais, nas experiências de espacialização das crianças pequenas.

Sem a inclusão da referência conceitual própria da Geografia o que se vai desenvolver com as crianças, quanto à espacialidade, é a descrição de trajetos e pontos de referência que poderão esvaziar de sentido o ensino que aborda o Lugar, Paisagem o que poderá levar ao risco do reducionismo didáticopedagógico.

Essas discussões devem ser inseridas no trabalho de reflexão da docência, em processos de formação em serviço, como vimos ocorrer em Diadema. Portanto projetos de trabalho serão essenciais para que as crianças possam apropriarse dos espaços de vivência na instituição e de outros espaços a partir do desenvolvimento de atividades, com base num rigoroso trabalho interdisciplinar, que rompa com a tendência a hierarquização dos saberes, próprio do modelo positivista tradicional que não deveria ser transposto para a etapa inicial da Educação Infantil, vindo das séries iniciais.

Finalizo ponderando que o papel estratégico que Yves Lacoste atribui as cartas no ensino da Geografia, propondo uma ruptura no modelo pedagógico acomodado, deve ser considerado também no âmbito da Educação Infantil introduzindo-se o trabalho com croquis de localização no eixo Conhecimento de Mundo para transformá-los em instrumentos e referências conceituais destinadas ao desenvolvimento do raciocínio e do pensamento geográfico. Estes, essenciais à formação e consolidação de uma cidadania ativa. 


\section{BIBLIOGRAFIA}

ARCE, A. Compre o Kit neoliberal para a Educação Infantil e ganhe grátis os dez passos para se tornar um professor reflexivo. Revista Educação e Sociedade, v. 22, n. 74. Campinas: abr. 2001. p. 251-283.

ARROYO. M. G. Ofício de Mestre - Imagens e auto-imagens. Petrópolis: Vozes, 2000.

BAQUERO, R. As relações entre linguagem e pensamento. In: Vygotsky e a aprendizagem escolar. Porto Alegre: Artes Médicas, 1998.

BRASIL. MINISTÉRIO DA EDUCAÇÃO E DO DESPORTO. SECRETARIA DE EDUCAÇÃO FUNDAMENTAL. Referencial Curricular Nacional para a Educação Infantil. Brasília: MEC/SEF, 1998.

BRUYNE, P. Dinâmica da Pesquisa em Ciências Sociais. RJ: Francisco Alves, $3^{\mathrm{a}}$ edição.

BUJES, M. I. E. A invenção do eu infantil: dispositivos pedagógicos em ação. Revista Brasileira de Educação, v. 21, n. 21. RJ: 2002. p. 17-39.

CARLOS, F. Espaço-Tempo na Metrópole: a fragmentação da vida cotidiana. SP: Contexto, 2001.

CAVALCANTI, L. S. Geografia da Cidade. Goiânia: Alternativa, 2001.

. Geografia, Escola e Construção de Conhecimentos. Campinas, SP: Papirus, 2001. (Coleção Magistério: Formação e Trabalho Pedagógico)

COSTA, E. V.; LYRA, M. C. D. P. Como a Mente se Torna Social para Barbara Rogoff? A Questão da Centralidade do Sujeito. Reflexão e Crítica, 15(3), Recife: 2002, pp. 637-647. 
DAHLBERG, G.; MOSS; P.; PENCE, A. Qualidade na Educação da Primeira Infância: perspectivas pós-modernas. Porto Alegre: Artmed, 2003.

DEMO, P. Conhecimento moderno: sobre ética e intervenção do conhecimento. Petrópolis: 1998.

DIAS, L. F. Croqui cartográfico no ensino da Geografia: ensaio metodológico. SP, 2000. Dissertação de Mestrado. FFLCH - Universidade de São Paulo.

DUARTE, N.; OLVEIRA, B. Socialização do Saber Escolar. SP: Cortez Editora, 1987 (Coleção Polêmicas do nosso tempo, v.18).

FAZENDA, I. Integração e interdisciplinaridade no ensino brasileiro. 4. ed. SP: Loyola, 1996.

. Interdisciplinaridade: História, teoria e pesquisa. 4. ed. Campinas: Papirus, 1999.

FERREIRA, S. Imaginação e Linguagem no Desenho da Criança. Campinas: Papirus, 1998.

FREITAS, L. A Produção de Ignorância na Escola. SP: Cortez, 1994.

GOHN, M. G. Movimentos Sociais e Educação. SP: Cortez, 1994. (Questões da nossa época; v.5)

HADJI, C. Pensar \& Agir: A Educação da inteligência, do desenvolvimento, o desenvolvimento da inteligência. Porto Alegre: Artmed, 2001.

HOFFMANN, J. Ação Educativa na Creche. Porto Alegre: Mediação, 2002.

JANTSCH, A. P.; BIANCHETTI, L. Interdisciplinaridade - Para além da filosofia do sujeito. Petrópolis: Vozes, 1997.

JAPIASSÚ, H. Interdisciplinaridade e patologia do saber. RJ: Imago, 1976. 
LACOSTE, Y. A Geografia - isso serve, em primeiro lugar, para fazer a guerra. Campinas, SP: Papirus, 2006.

LOPES, E.; MACEDO, A.C. (Orgs.). O pensamento curricular no Brasil. In Currículo: debates contemporâneos. SP: Cortez, 2002 (série Cultura, Memória e Currículo, v.2).

LURIA, A. R. Curso de Psicologia Geral. RJ: Civilização Brasileira, 1991. v. III. ; YUDOVICH. Linguagem e desenvolvimento intelectual na criança. Porto Alegre: 1985.

; VYGOTSKY, L. S. et al. Psicologia e Pedagogia: Bases Psicológicas da Aprendizagem e do Desenvolvimento. SP: Moraes, 1991.

MARTINELLI, M. Mapas da Geografia e Cartografia Temática. SP: 2003.

MENESES, J. G. C. et al. Estrutura e Funcionamento da Educação Básica. SP: Pioneira, 1999.

MOLL, L. Vígotsky e a educação. Implicações pedagógicas da Psicologia Sócio- histórica. Porto Alegre: Artes Médicas, 1996.

MORAES, A. C. R. A Gênese da Geografia Moderna. SP: Hucitec: Annablume, 2002.

MOREIRA, R. Assim se Passaram Dez Anos (A Renovação da Geografia no Brasil no período 1978 - 1988). GEOgraphia, RJ: 2000.

NÉBIAS, C. Formação de Conceitos Científicos e Praticas Pedagógicas. Revista Interfaces. Comunicação, Saúde e Educação. Vol. 3. n 4. Botucatu: UNESP/ Fundação UNI,. fev. 1999, (133 - 142).

NEWMAN, F.; HOLZMAN, L. Lev Vigotsky: cientista revolucionário. S. Paulo: Loyola, 2002. 
NÓBREGA, M. L. S. Escola-Padrão: Autonomia e Gestão Democrática. Dissertação de Mestrado, Universidade Estadual de Campinas, 1999.

OLIVEIRA, A. U. Para onde vai o ensino de Geografia? SP: Contexto, 1998.

OLIVEIRA, M. K. Vigotsky, aprendizado e desenvolvimento um processo sóciohistórico. SP: Scipione, 1995.

; OLIVEIRA, M. (Orgs.). Investigações cognitivas: conceitos, linguagem e cultura. Porto Alegre: Artes Médicas, 1999.

OLIVEIRA, S M. L. A legislação e as políticas nacionais para a educação infantil: avanços, vazios e desvios. In MACHADO, M. L. A. (Org.) Encontros e Desencontros em Educação Infantil. São Paulo: Cortez, 2002. p. 35-42.

OLIVEIRA, Z. M. (Org.) Educação infantil: muitos olhares. SP: Cortez, 1996.

. Educação Infantil: fundamentos e métodos. SP: Cortez: 2002

PALANGANA, I. C. Desenvolvimento e aprendizagem em Piaget e Vygotsky (A relevância do social). SP: Plexus, 1994.

RATNER, C. A psicologia sócio-histórica de Vygotsky. Porto Alegre: Artes Médicas, 1995.

RODRIGUES, N. Por Uma Nova Escola - O transitório e o permanente na educação. SP: Cortez, 2000.

ROGOFF, B. Apprenticeship in Thinking. New York: New York University Press, 1990.

SANTOS, B. S. (Org.). A Globalização e as Ciências Sociais. SP: Cortez, 2002.

SANTOS, M. Por uma outra globalização - do pensamento único à consciência universal. SP: Record, 2003. 
SAVIANI, D. Escola e Democracia. Campinas, SP: Mercado das Letras, 1994.

SILVA, T. T. Documentos de Identidade: Uma introdução às teorias do currículo. Belo Horizonte: Autêntica, 2001.

SIMIELLI, M. E. R. Primeiros Mapas: como entender e construir. SP: Ática, 1993.

. Cartografia e Ensino: proposta e contraponto de uma obra didática. SP: 1996. (sistematização crítica de obra publicada, apresentada para Concurso de Livre- Docência - FFLCH-USP)

- O Mapa como Meio de Comunicação: implicações no ensino da Geografia de $1^{\circ}$ Grau. SP: 1986. Tese de Doutorado (FFLCH-USP).

. Cartografia no Ensino Fundamental e Médio. In A Geografia na Sala de aula. SP: Contexto, 2001. (Repensando o Ensino).

SOUZA, P. N.; SILVA, E. B. Como entender e aplicar a nova LDB. SP: Pioneira, 2001.

SPOSITO, M. E. Capitalismo e Urbanização. SP: Contexto, 2001.

STEINER, V. J; SOUBERMAN, E. Posfácio. In: VYGOTSKY, L.A. A formação social da mente. 6. ed. SP: Martins Fontes, 1998.

VALSINER, J.; DER VEER, R. Vygotsky, uma síntese. SP: Unimarco Ed., 1996.

VÁZQUEZ, A. S. Filosofia da Práxis. RJ: Paz e Terra, 1977.

VEIGANETO, A. J. A ordem das disciplinas. Tese de Doutorado. Universidade Federal do Rio Grande do Sul. Porto Alegre: 1996.

VESENTINI, J. W. Novas Geopolíticas. SP: Contexto, 2000.

VYGOTSKY, L. S. Pensamento e Linguagem. SP: Martins Fontes, 1991. 
A formação social da mente. SP: Martins Fontes. 1994.

Obras escogidas. Vol. III e IV. Madrid: Visor, 1995.

_ aprendizagem. SP: Ícone / Editora da Universidade de São Paulo, 1988. (Coleção Educação Crítica). 